LA-14250

Approved for public release;

distribution is unlimited.

Measurements of Air Contaminants during the Cerro Grande Fire at Los Alamos

National Laboratory
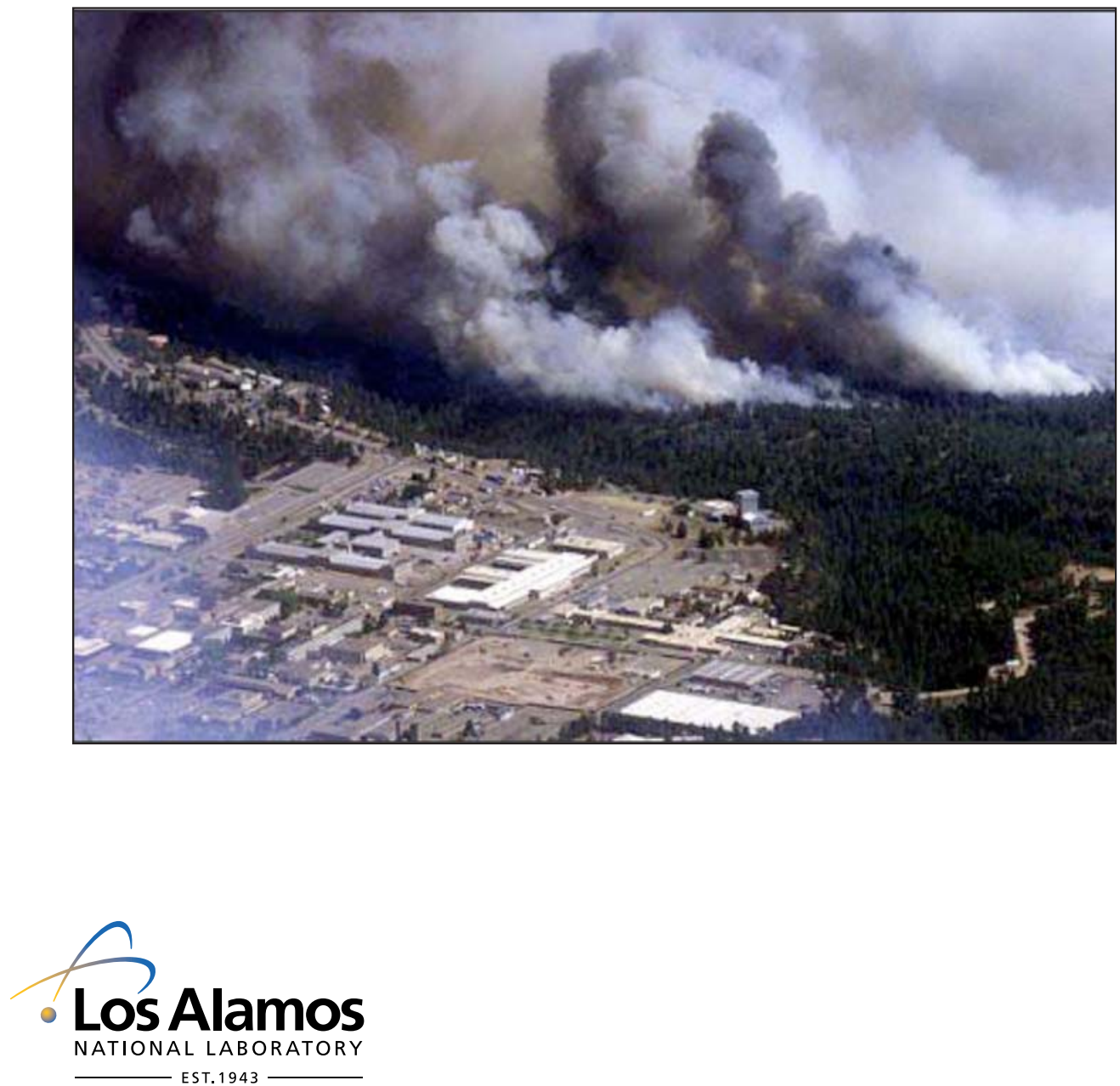
Edited by Hector Hinojosa, Group IRM-CAS.

\section{Cover photo:}

The smoke plume from the Cerro Grande fire. (LANL photo)

Los Alamos National Laboratory, an Affirmative Action/ Equal Opportunity Employer, is operated by Los Alamos National Security, LLC, for the National Nuclear Security Administration of the U.S. Department of Energy under contract DE-AC52-06NA25396

This report was prepared as an account of work sponsored by an agency of the U.S. Government. Neither Los Alamos National Security, LLC, the U.S. Government nor any agency thereof, nor any of their employees make any warranty, express or implied, or assume any legal liability or responsibility for the accuracy, completeness, or usefulness of any information, apparatus, product, or process disclosed, or represent that its use would not infringe privately owned rights. Reference herein to any specific commercial product, process, or service by trade name, trademark, manufacturer, or otherwise does not necessarily constitute or imply its endorsement, recommendation, or favoring by Los Alamos National Security, LLC, the U.S. Government, or any agency thereof. The views and opinions of authors expressed herein do not necessarily state or reflect those of Los Alamos National Security, LLC, the U.S. Government, or any agency thereof. Los Alamos National Laboratory strongly supports academic freedom and a researcher's right to publish; as an institution, however, the Laboratory does not endorse the viewpoint of a publication or guarantee its technical correctness. 
LA-14250

Issued: August 2010

Measurements of Air Contaminants during

the Cerro Grande Fire at Los Alamos

National Laboratory

Craig Eberhart

- Los Alamos 



\section{CONTENTS}

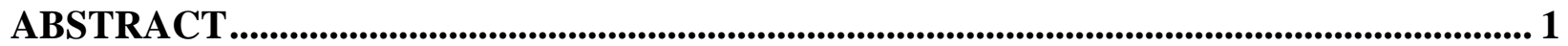

INTRODUCTION

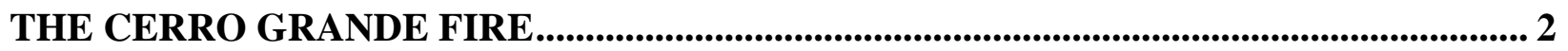

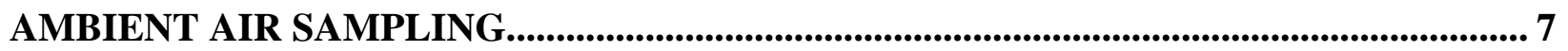

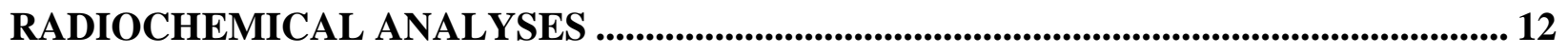

GROSS ALPHA AND GROSS BETA ACTIVITY ......................................................... 16

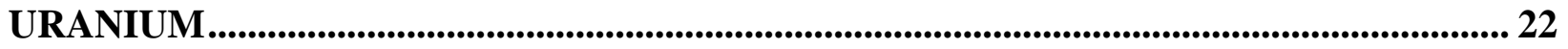

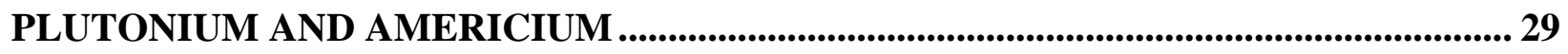

OTHER RADIONUCLIDES AS MEASURED BY GAMMA SPECTROSCOPY.............. 32

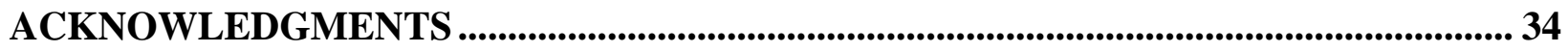

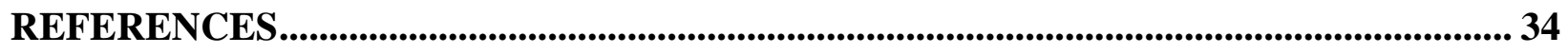

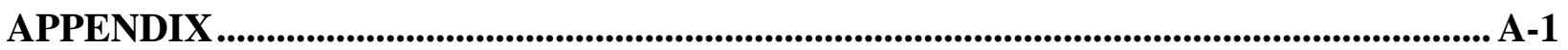

\section{List of Tables}

Table 1. May 2000 Sample Designations and the Number of Samples .............................................. 11

Table 2. Comparison of AIRNET 'Normal’ and Fire-Related Analysis................................................ 13

Table 3. Air Concentration Appendix Tables by Analytes and Time Period ...................................... 15

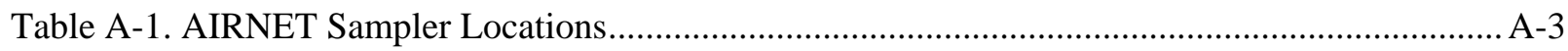

Table A-2. Validated AIRNET Samples Collected in May 2000 .....................................................A-4

Table A-3. Rejected AIRNET Samples Collected in May 2000 .....................................................7

Table A-4. Samples With More Than 5\% Downtime during the May 2000 Collection Period ............. A-7

Table A-5. Time Sampled by Sampling Period during May 2000 .................................................... A-8

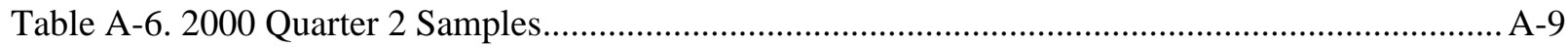

Table A-7. Clumps of May 2000 Filters Analyzed by Gamma Spectroscopy …................................... A-10

Table A-8. Short-term Gross Alpha Concentrations for May 2000 Samples .........................................11

Table A-9. Short-term Gross Beta Concentrations for May 2000 Samples.......................................... A-13

Table A-10. Short-term Gross Alpha and Gross Beta Concentrations above their 3s Uncertainties..... A-15

Table A-11. Biweekly Gross Alpha Concentrations for May 2000 Samples ...................................... A-17 
Table A-12. Biweekly Gross Beta Concentrations for May 2000 Samples .......................................... A-19

Table A-13. Biweekly Gross Alpha and Gross Beta Concentrations above their 3s Uncertainties ....... A-21

Table A-14. Gamma Spectroscopy Measurements for May 2000 Clumps ............................................ A-23

Table A-15. Gamma Spectroscopy Measurements above their 3s Uncertainties ................................... A-24

Table A-16. Biweekly and Short-term Americium-241 Concentrations for May 2000 Samples .......... A-25

Table A-17. Biweekly and Short-term Plutonium-238 Concentrations for May 2000 Samples ............ A-27

Table A-18. Biweekly and Short-term Plutonium-239 Concentrations for May 2000 Samples ............ A-29

Table A-19. Biweekly and Short-term Uranium-234 Concentrations for May 2000 Samples................ A-31

Table A-20. Biweekly and Short-term Uranium-235 Concentrations for May 2000 Samples............... A-33

Table A-21. Biweekly and Short-term Uranium-238 Concentrations for May 2000 Samples............... A-35

Table A-22. Biweekly and Short-term Uranium, Plutonium, and Americium Concentrations above

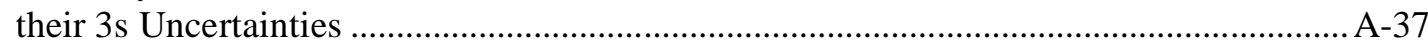

Table A-23. Polonium-210 and Lead-210 Concentrations Measured in May 2000............................... A-39

Table A-24. Polonium-210 and Lead-210 above their 3s Uncertainties ................................................ A-40

Table A-25. Americium-241 Concentrations for 2000 Quarter 2 ........................................................ A-41

Table A-26. Plutonium-238 Concentrations for 2000 Quarter 2 ......................................................... A-42

Table A-27. Plutonium-239 Concentrations for 2000 Quarter 2 ........................................................... A-43

Table A-28. Uranium-234 Concentrations for 2000 Quarter 2 …......................................................... A-44

Table A-29. Uranium-235 Concentrations for 2000 Quarter 2 ….......................................................... A-45

Table A-30. Uranium-238 Concentrations for 2000 Quarter 2 ….......................................................A-46

Table A-31. Quarterly Uranium, Plutonium, and Americium Concentrations above their 3s Uncertainties

\section{List of Figures}

Figure 1. Uranium-238 decay series............................................................................................. 3

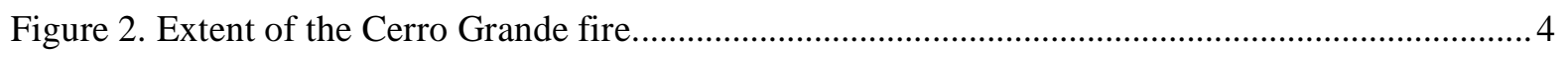

Figure 3. Location of five major wildfires in the LANL region............................................................ 5

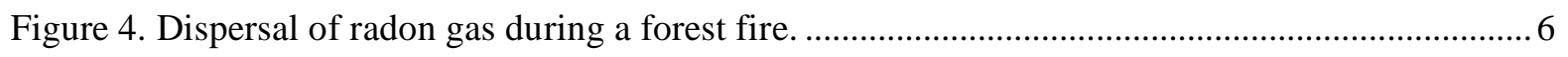

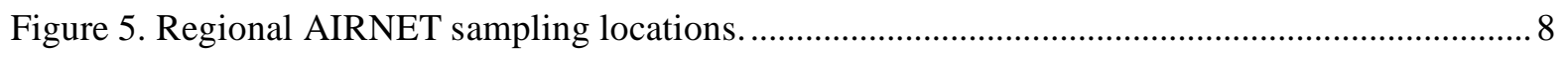

Figure 6. AIRNET sampling locations in Los Alamos County............................................................ 9

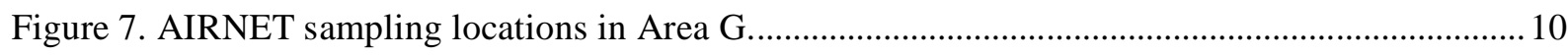

Figure 8. The effects of sampled uranium, plutonium, and americium uncertainties. ........................... 14

Figure 9. Americium-241 concentrations before and after blank corrections........................................ 14

Figure 10. Radon-222 decay chain: shorter-lived radionuclides. ........................................................ 17

Figure 11. Radon-222 decay chain: longer-lived radionuclides. ........................................................ 17 


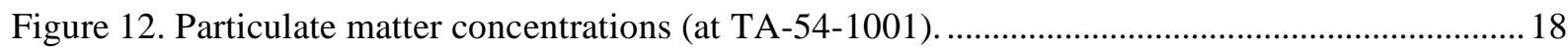

Figure 13. Gross alpha and gross beta measurements during the Cerro Grande and other fires............ 18

Figure 14. Gross alpha and gross beta measurements (at greater resolution) during the

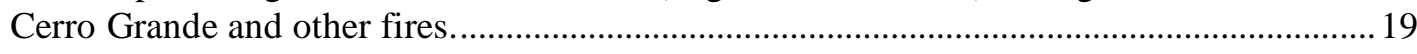

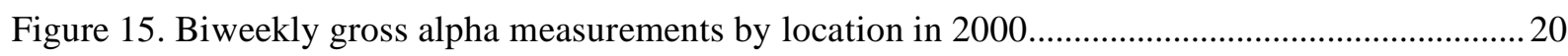

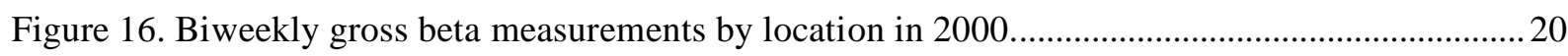

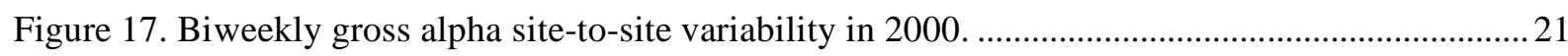

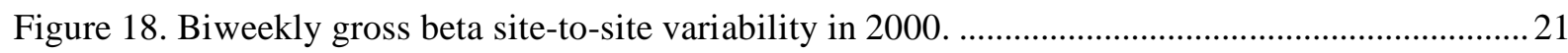

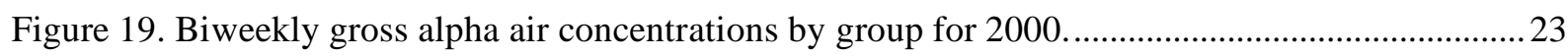

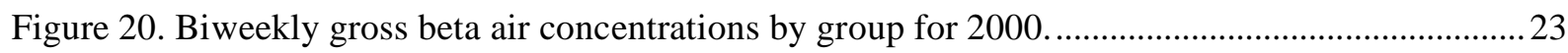

Figure 21. Biweekly gross alpha concentrations for AIRNET sites with the highest concentration

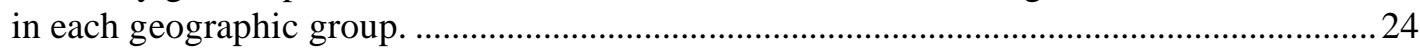

Figure 22. Biweekly gross beta concentrations for AIRNET sites with the highest concentration

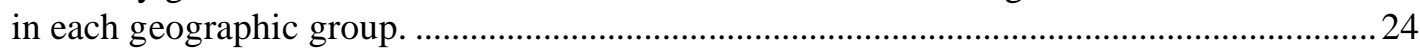

Figure 23. Gross alpha measurements versus polonium-210 measurements during the Cerro Grande fire.

Figure 24. Gross beta measurements versus lead-210 measurements during the Cerro Grande fire.....25

Figure 25. Short-term uranium isotopic concentrations during the Cerro Grande fire. .......................... 27

Figure 26. Quarter 2 uranium isotopic concentrations. ........................................................................ 27

Figure 27. AIRNET quarterly uranium concentrations (network-wide concentrations

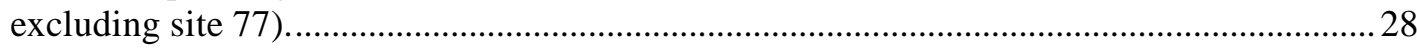

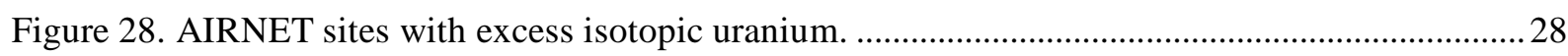

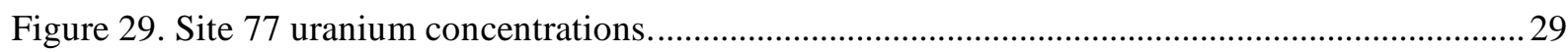

Figure 30. Two-week americium and plutonium concentrations at the beginning of the

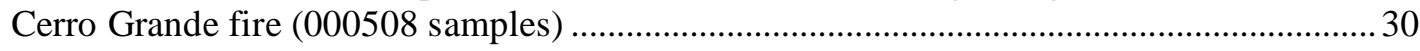

Figure 31. Short-term americium and plutonium concentrations during the Cerro Grande fire

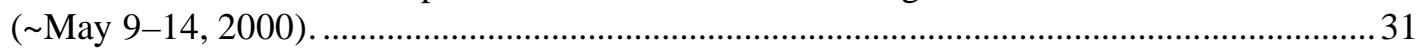

Figure 32. Second quarter 2000 americium and plutonium concentrations............................................ 31

Figure 33. AIRNET quarterly plutonium and americium concentrations............................................. 32

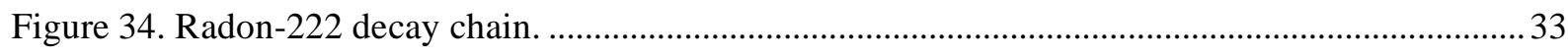

Figure 35. Beryllium-7 gamma spectroscopy measurements grouped by general location.................... 33

Figure 36. Lead-210 gamma spectroscopy measurements grouped by general location........................ 34 


\title{
Measurements of Air Contaminants during the Cerro Grande Fire at Los Alamos National Laboratory \\ by
}

\author{
Craig Eberhart, Environmental Data and Analysis Group, LANL
}

\begin{abstract}
Ambient air sampling for radioactive air contaminants was continued throughout the Cerro Grande fire that burned part of Los Alamos National Laboratory. During the fire, samples were collected more frequently than normal because buildup of smoke particles on the filters was decreasing the air flow. Overall, actual sampling time was $96 \%$ of the total possible sampling time for the May 2000 samples. To evaluate potential human exposure to air contaminants, the samples were analyzed as soon as possible and for additional specific radionuclides. Analyses showed that the smoke from the fire included resuspended radon decay products that had been accumulating for many years on the vegetation and the forest floor that burned. Concentrations of plutonium, americium, and depleted uranium were also measurable, but at locations and concentrations comparable to non-fire periods. A continuous particulate matter sampler measured concentrations that exceeded the National Ambient Air Quality Standard for PM-10 (particles less than 10 micrometers in diameter). These high concentrations were caused by smoke from the fire when it was close to the sampler.
\end{abstract}

\section{Introduction}

Extensive air monitoring data were collected during the Cerro Grande fire in May 2000. These measurements are compared to pre- and post-fire data to evaluate effects of the fire on ambient air concentrations of natural and anthropogenic radionuclides. The data were collected using the radiological air sampling network, referred to as AIRNET, at Los Alamos National Laboratory (LANL). This network was designed to measure environmental levels of airborne radionuclides that may be released from LANL operations, which include plutonium, americium, uranium, and tritium. In addition, these measurements include natural radionuclides such as lead-210, beryllium-7, and natural uranium.

Regional airborne radioactivity is largely composed of fallout from past atmospheric nuclear weapons tests by several countries, natural radioactive constituents in particulate matter such as uranium and thorium, terrestrial radon diffusing out of the earth and its subsequent decay products, and radionuclides resulting from interactions with cosmic radiation. As currently configured, AIRNET is not sensitive enough to measure regional levels of americium, plutonium, or tritium. Natural uranium is usually detected in AIRNET samples because it is present in local soils, which are the largest source of particulate matter collected on the filters. Gamma spectroscopy analyses normally detect beryllium-7 produced by spallation of common atmospheric gases by cosmic radiation. 
The primary source of natural radioactivity measured on the AIRNET filters is from the radon222 decay chain (Figure 1). Radon-222 decay products are virtually always detected by gross alpha activity (polonium-210), gross beta activity (bismuth-210), and gamma spectroscopic analyses (lead-210).

Past and current activities at LANL impact ambient air concentrations of radionuclides in the ambient air onsite and around the perimeter of the Laboratory. Measurable concentrations of plutonium, americium, and tritium indicate a Laboratory impact. Plutonium and americium are occasionally measured onsite, primarily near decontamination and decommissioning operations and at the Laboratory's low-level radioactive waste disposal site (Area G). Low concentrations of americium and plutonium have also been detected in occasional samples offsite near the perimeter of the Laboratory. Depleted uranium is occasionally detected onsite and offsite around the perimeter of the Laboratory due to the resuspension of soils with depleted uranium from past Laboratory activities. Measurable concentrations of tritium, which are not included in this paper, are detected at most onsite locations and at nearby offsite locations. Concentrations for all of these LANL-related radionuclides at offsite locations have never exceeded more than several percent of the US Environmental Protection Agency (EPA) public dose limit.

\section{The Cerro Grande Fire}

On May 4, 2000, the National Park Service initiated a prescribed burn within Bandelier National Monument. The burn was in a meadow on the flanks of Cerro Grande Peak about 3.5 miles west of the northwest corner of the Laboratory. By the following day, the burn was out of control and declared a wildfire. The fire ultimately burned about 43,000 acres of public, private, and pueblo lands, which included about 7,500 acres of Laboratory land (Figure 2) before being fully contained by June 2000. One hundred twelve Laboratory structures and 235 residential structures in the town site were damaged or destroyed (LANL 2000). This fire was the fifth major wildfire in the LANL region in the last 50 years (Figure 3).

The Cerro Grande fire dramatically influenced concentrations of particulate matter and radioactivity in the ambient air. This fire, or any vegetation fire worldwide, releases radioactivity in and on the burned material to the atmosphere. Because the Cerro Grande fire was burning forests that had not burned for many years (Figure 3), we expected increases in alpha and beta concentrations from the resuspension of lead-210, bismuth-210, and polonium-210. These are constantly being deposited in forests and have been accumulating for many years (Figure 4). As radon gas decays in the atmosphere, it creates charged radioactive particles, many of which deposit on suspended particulate matter or other surfaces such as leaves and needles. Typical atmospheric concentrations of these radioactive particles are measurable by AIRNET, but relatively small when compared to the inventory present in the forests that were burned by the Cerro Grande fire. When these forests were burned, the heat and turbulence from the fire were very effective at resuspending these radioactive elements from the surfaces of vegetation, the forest floor, and the soil surface. 


\section{Uranium-238 (primordial) \\ uranium-238 measured by alpha spectroscopy}

Various decay products including uranium-234

uranium-234 measured by alpha spectroscopy

Radon-222

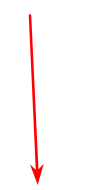

Short-lived decay products

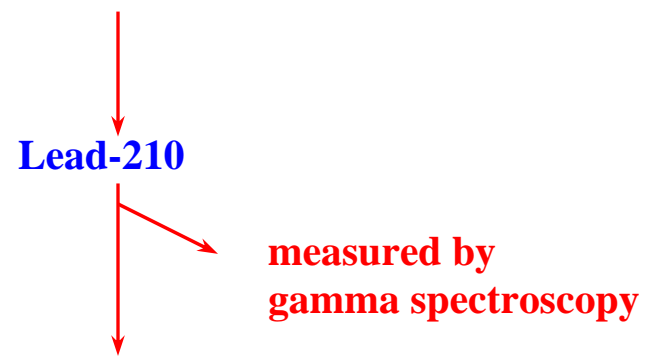

Bismuth-210

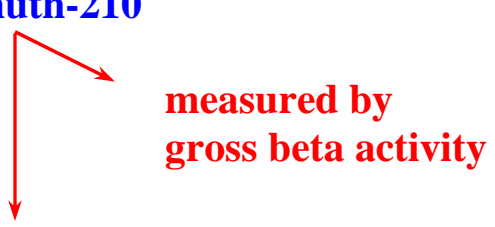

Polonium-210

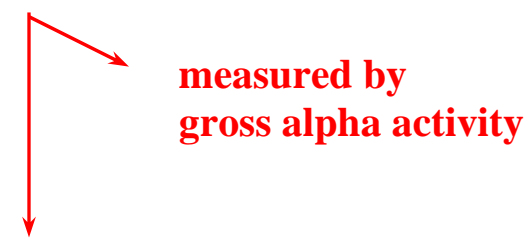

Lead-206
Terrestrial.

Present in sampled particulate matter.

4.5-billion-year half-life

Terrestrial.

Present in sampled particulate matter. 246-thousand-year half-life

Released to the atmosphere as a gas. 3.8-day half-life

Gas to particulate matter.

Not present by analysis time

Present in sampled particulate matter.

22-year half-life

Accumulates over years

Present in sampled particulate matter.

5-day half-life

Equilibrates with lead-210 in 35 days

Present in sampled particulate matter.

138-day half-life

Equilibrates with lead-210 in $~ 2.6$ years

Stable

Figure 1. Uranium-238 decay series. 


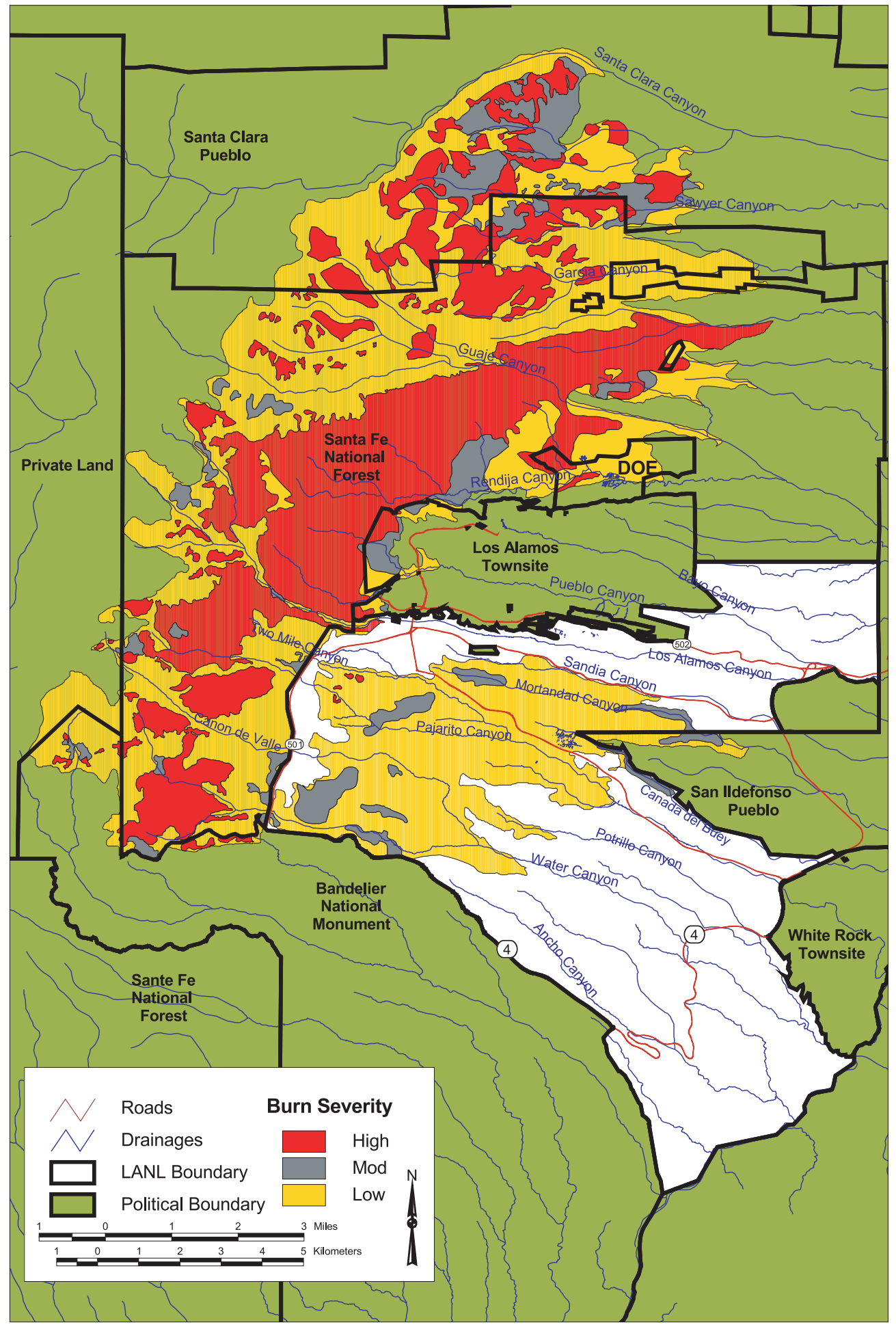

Figure 2. Extent of the Cerro Grande fire. 


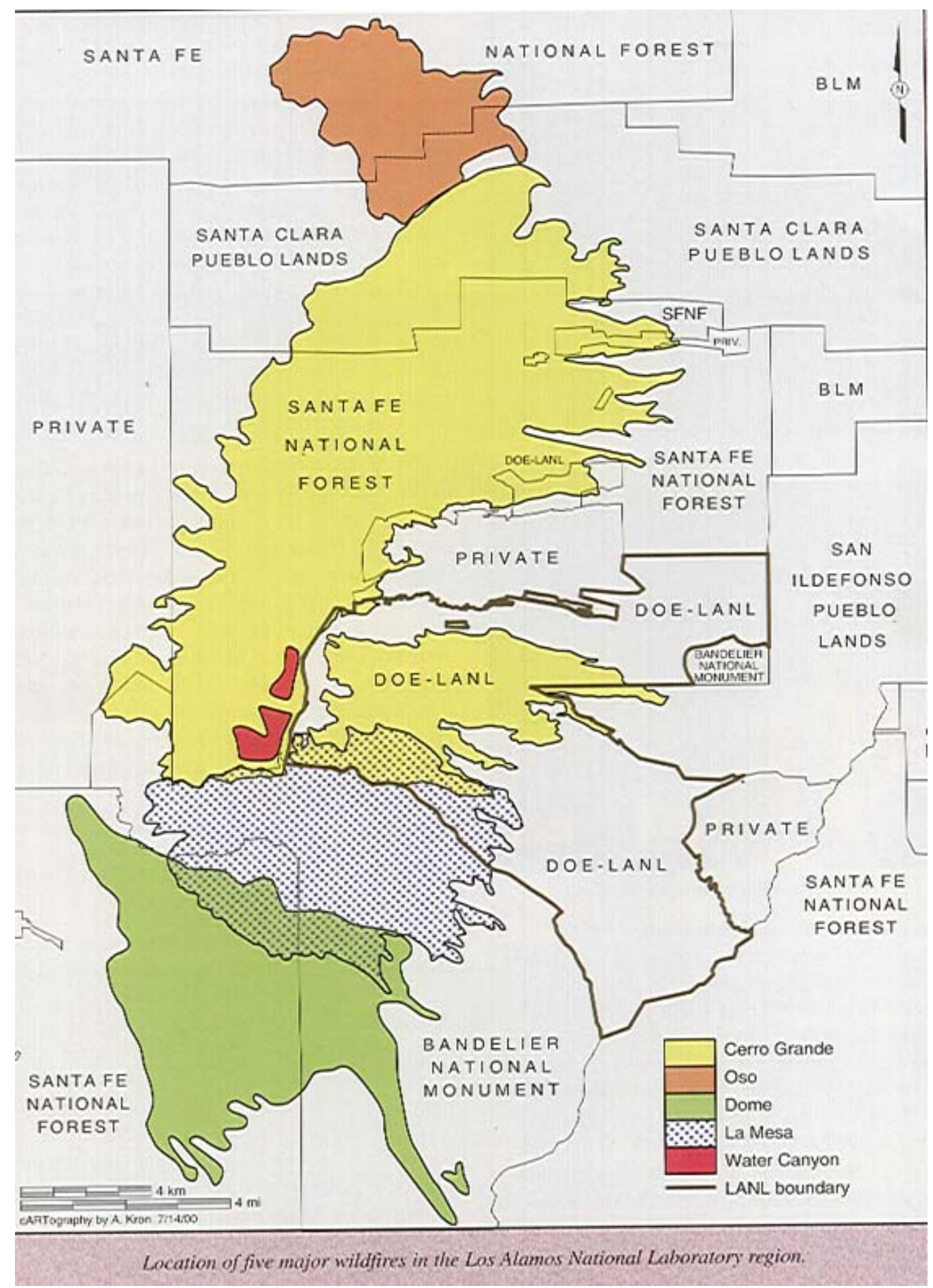

Figure 3. Location of five major wildfires in the LANL region. The Cerro Grande fire occurred in 2000, the Oso fire in 1998, the Dome fire in 1997, the La Mesa fire in 1977, and the Water Canyon fire in 1954. 

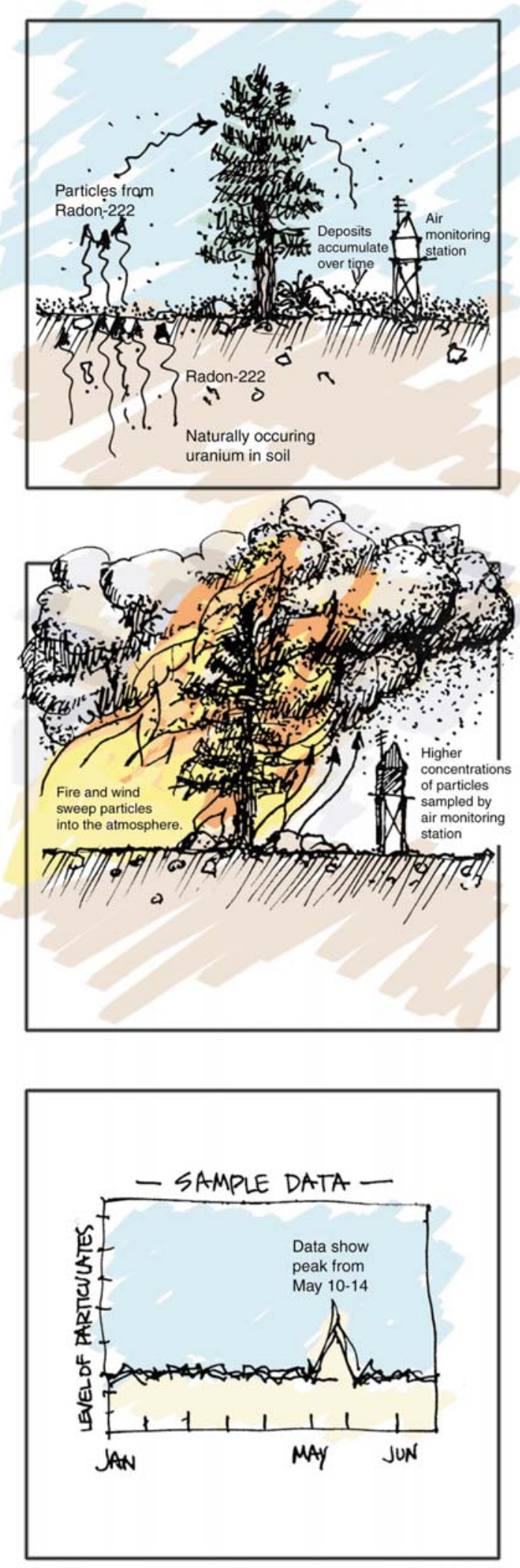

BEFORE THE FIRE - Radon-222 is

released to the atmosphere as a gas from the decay of natural terrestrial uranium. This radon decays to other radioactive elements, which are present as fine, highly charged particles. These particles are removed from the atmosphere by precipitation or deposited onto surfaces such as vegetation and the forest floor.
DURING THE FIRE - The turbulence and the heat from the burning vegetation during the Cerro Grande fire rapidly resuspend the accumulated radon decay products and other radioactive elements such as natural uranium in soils. These radionuclides are present in the smoke from the fire.
AFTER THE FIRE - When we analyzed the samples from our air monitoring stations, our analyses of the time period when the fire was burning showed higher concentrations that reflect the rapid release of these accumulated natural radionuclides.

Figure 4. Dispersal of radon gas during a forest fire. 
Fires may also entrain additional particulate matter from the Earth's surface by physical turbulence associated with burning, or they may burn contaminated material and release the radionuclides therein. The temperature of the fire and the volatility of the elements or compounds will greatly influence ambient concentrations. The extremely dry conditions and high wind speeds, which were major factors in the spread of the Cerro Grande fire, may have also caused additional resuspension of natural and anthropogenic radionuclides. Depleted uranium, americium, plutonium, and other radionuclides, which are present at LANL, could be released to the atmosphere by these conditions.

\section{Ambient Air Sampling}

During the Cerro Grande fire, the Laboratory operated 49 AIRNET stations to sample the ambient air for radionuclides. Generally, each AIRNET sampler continuously collects particulate matter for approximately two weeks. Particulate matter is collected on 47-mm polypropylene filters at an airflow rate of about $0.11 \mathrm{~m}^{3}$ per minute, which is about $2200 \mathrm{~m}^{3}$ per sampling period. For AIRNET, sampling periods are normally designated based on the Monday of the sampling collection week. Therefore, samples collected the week beginning Monday, May 8, would be designated as sample period 000508 (yymmdd format). In the tables, the numbers to the right of the decimal point represent the location or site number. For example, 000508.10 is the biweekly sample collected the week of May 8 from site 10 (Eastgate). Additional short-term sampling periods were added during the fire because multiple samples from one location were collected within a biweekly sampling period.

Appendix Table A-1 lists stations that operated during the fire along with site number, site name, and location (latitude, longitude, and altitude). Four regional sampling stations are used to determine regional background and fallout levels of atmospheric radioactivity. These regional stations are located in Española, El Rancho, and two locations in Santa Fe. Pueblo monitoring stations are located at San Ildefonso and Jemez Pueblos. About 20 perimeter stations are located in the populated areas of Los Alamos County and within $4 \mathrm{~km}$ of the Laboratory boundary. Finally, because maximum concentrations from airborne releases of radionuclides are likely to occur onsite, more than 20 stations are within the Laboratory boundary. AIRNET sampling locations are shown regionally (Figure 5), in Los Alamos County (Figure 6), and at Area G (Figure 7).

The first samples that may have been impacted by fire emissions were biweekly particulate matter filters collected on May 9 or May 10. By this time, accumulation of smoke particles on some of the filters was becoming a problem because they were clogging the filters and reducing the sample airflow rate. Therefore, filters were replaced as often as possible in subsequent days (May 11 through May 14) to decrease the potential for air sampling rates dropping to zero. After May 14, filters were not exchanged until the week beginning Monday, May 22. Samples collected on May 11 through May 22 are considered short-term samples because they represent less than two weeks of sampling. However, biweekly air concentrations were calculated for the May 22 samples (000522) by combining analytical results from these multiple samples. The May 2000 sample designations and the number of samples collected are presented in Table 1. 


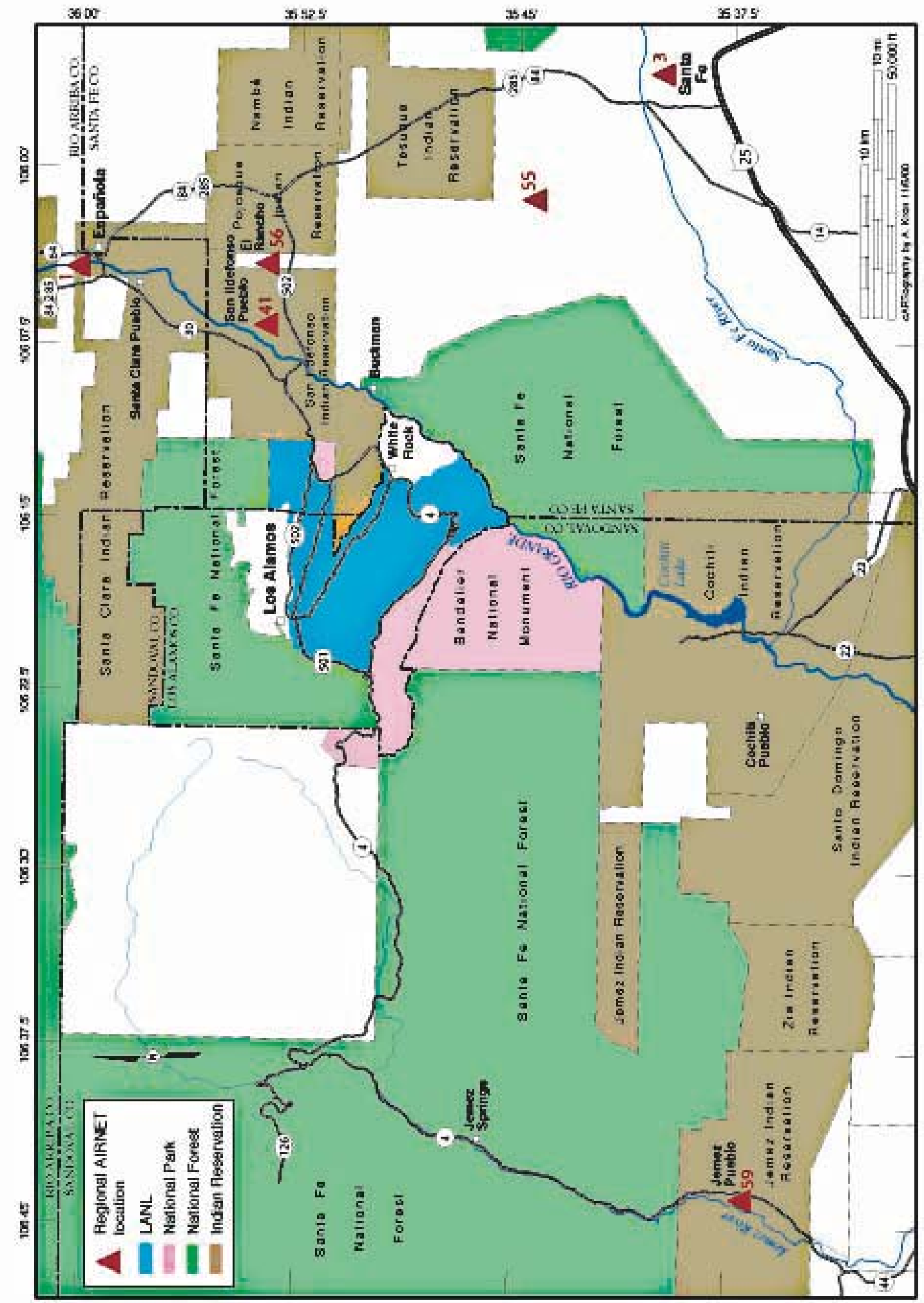

Figure 5. Regional AIRNET sampling locations. 


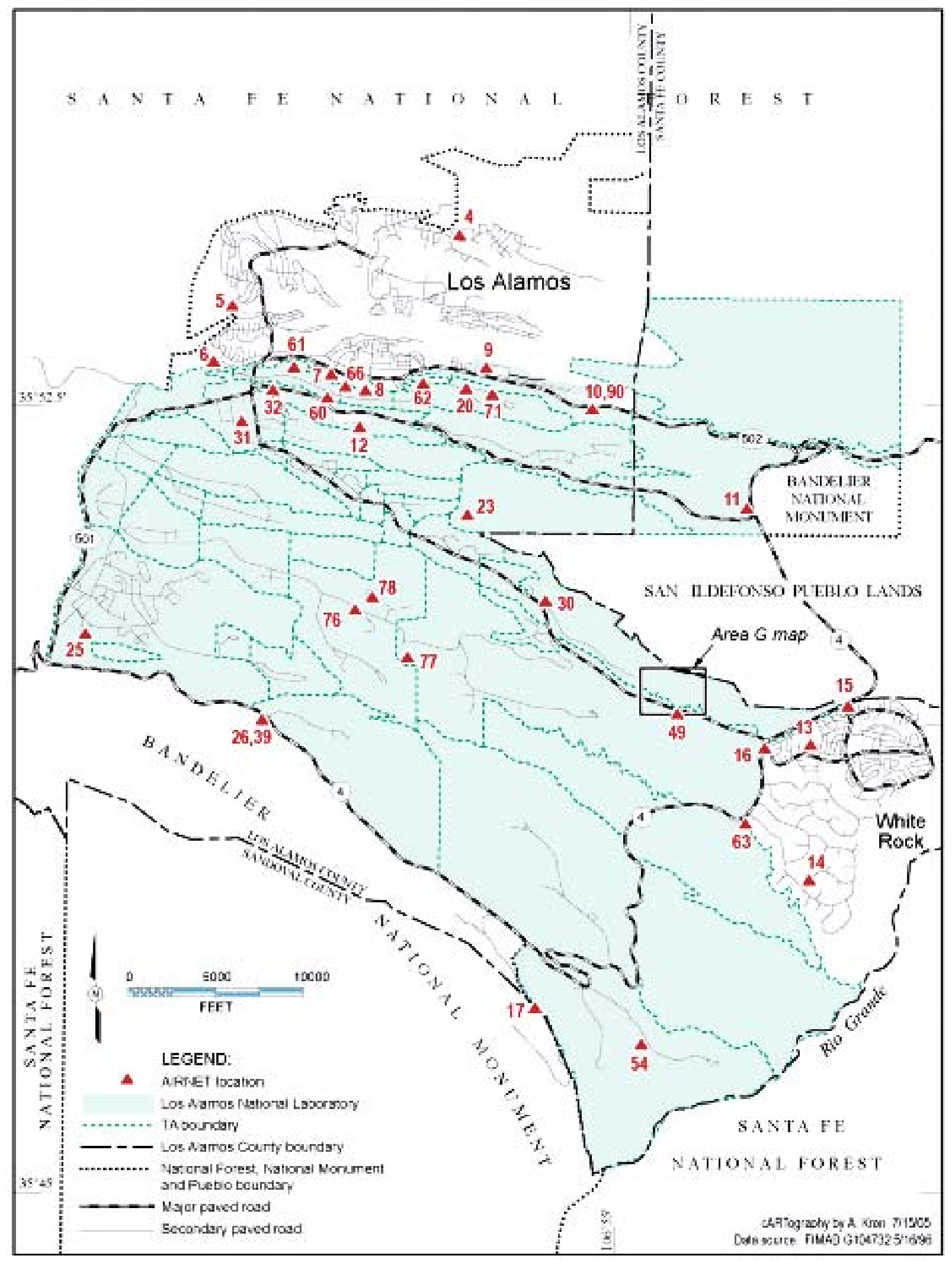

Figure 6. AIRNET sampling locations in Los Alamos County. 


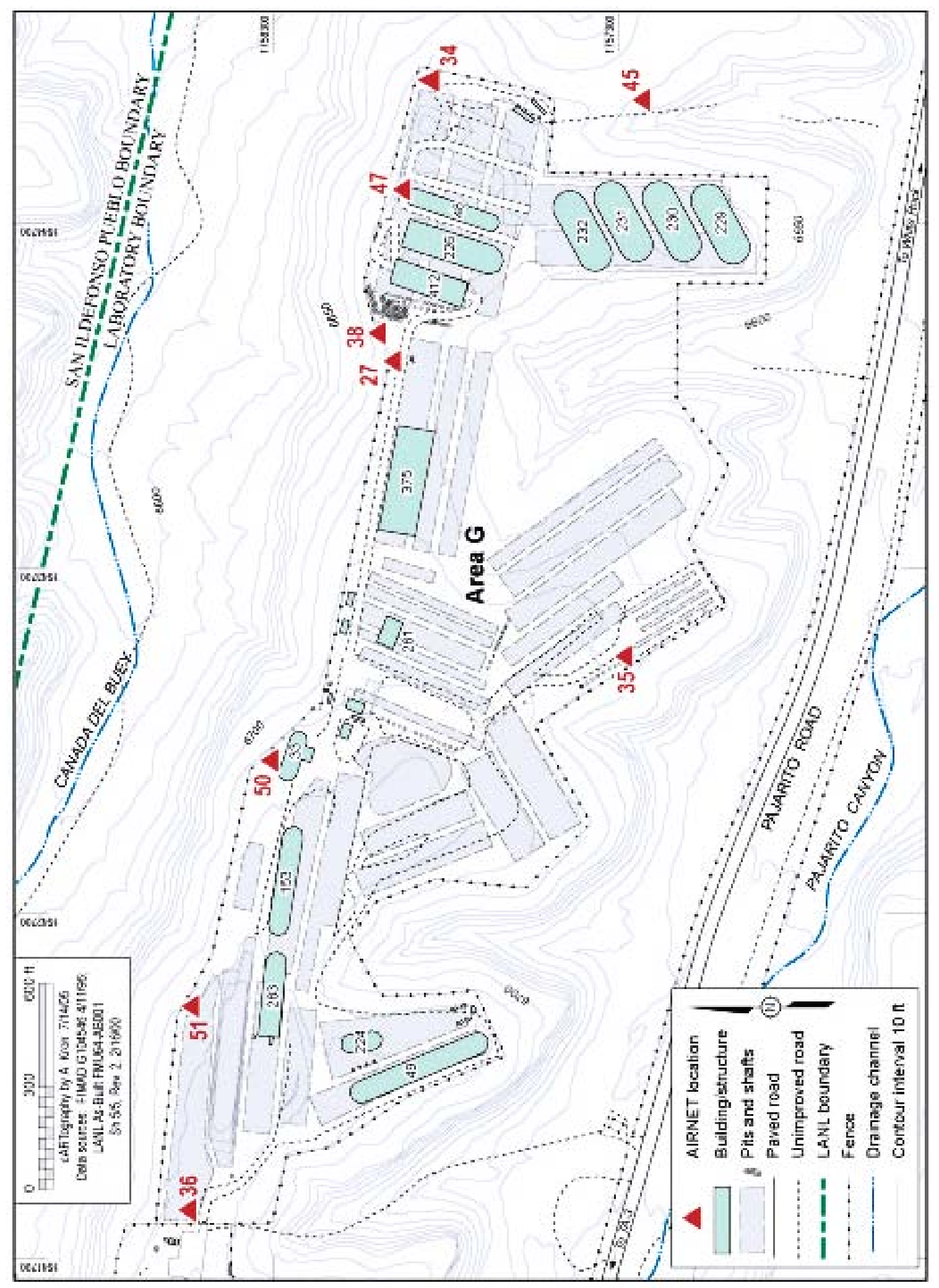

Figure 7. AIRNET sampling locations in Area G. 
Table 1. May 2000 Sample Designations and the Number of Samples

\begin{tabular}{|l|c|c|c|c|}
\hline $\begin{array}{l}\text { Actual Sample } \\
\text { Collection Date }\end{array}$ & $\begin{array}{c}\text { Sample Period } \\
\text { (yymmdd) }\end{array}$ & $\begin{array}{c}\text { Nominal } \\
\text { Sample Date }\end{array}$ & Time period & $\begin{array}{c}\text { Number of } \\
\text { samples }\end{array}$ \\
\hline May 9-10 & 000508 & $5 / 8$ & biweekly & 49 \\
\hline May 11 & 000511 & $5 / 11$ & short term & 16 \\
\hline May 12 & 000512 & $5 / 12$ & short term & 16 \\
\hline May 13 & 000513 & $5 / 13$ & short term & 24 \\
\hline May 14 & 000514 & $5 / 14$ & short term & 19 \\
\hline May 22-24 & 000522 & $5 / 22$ & short term & 49 \\
\hline
\end{tabular}

A total of 173 samples were collected in May 2000. Based on the technical validation and verification of the samples, 161 (93\%) were accepted (Table A-2) and 12 (7\%) were rejected (Table A-3). Each sample in these two tables represents one filter along with its sample period, sample number, and starting and ending dates and times. The sampled air volumes, which range from 98 to $2652 \mathrm{~m}^{3}$, are included for accepted samples. The rejected samples in Table A-3 show the reason for rejection. The air concentrations in this report do not include any data from rejected samples.

In addition to rejected samples, there were times during the fire when air was not being sampled at some locations. About $13 \%$ of the May samples (22 of 173) were collecting samples for less than $95 \%$ of the possible sampling time (Table A-4). In most cases, loss of electrical power caused the lost sampling time. Overall, the actual sampling time as a percent of the possible sampling time was $96 \%$ for the May sampling periods. The actual sampling time with validated and verified samples represents 93\% of the possible sampling time during May 2000 (Table A5).

To compare the normal biweekly measurements to data collected during the fire, analytical results from the short-term samples were combined to calculate biweekly concentrations for the $5 / 22$ sampling period. The 5/22 samples shown in Table A-2 are field data for individual filters that were collected the week of May 22. Except for one sample location, these samples do not represent the May 22 two-week sampling period because intermediate samples were collected. Additionally, site 90, the Eastgate backup site, was not counted or analyzed for any radionuclides because, at the time, it was only operated to provide a backup sample to replace rejected samples for the Eastgate site (10). Airflow rates were generally lower for short-term samples because many of these samples had high levels of particulate matter from the smoke and resuspended dust. Therefore, the data compositing process weighted the concentrations and their uncertainties by the sampling time instead of by the sampled air volume. Every 5/22 biweekly air concentration includes all valid samples collected at each site since the 5/08 samples were collected. These composited air concentrations and the 5/08 air concentrations are referred to as biweekly samples or biweekly air concentrations. The air concentrations for individual filters collected during the 5/22 sample period are referred to as short-term samples or short-term air concentrations. 
A list of the verified and validated quarterly composite samples for the second calendar quarter of 2000 is shown in Table A-6 along with their sampled air volumes. Similar to the biweekly numbering scheme, the sample period for the second quarter of 2000 is designated as 00Q2 while the two numbers to the right of the decimal designate the sampling site or location. The sampled air volumes listed in this table represent the summed air volumes for the filters that were included in the composite sent to the laboratory for isotopic analysis. Some half-filters were missing from these composites because both halves had been used for isotopic analyses of the biweekly and short-term samples collected during the fire. If a half-filter was not available for compositing, the analytical results were composited based on the sampling time to calculate the quarterly air concentrations and their uncertainties.

The final sample type was filters grouped together across geographically similar sites, designated as "clumps," and analyzed for gamma-emitting radionuclides. Normally these are clumps of six to nine filters collected for the same biweekly sampling period. Because most of the samples collected during the fire were only part of the 5/22 biweekly period, short-term clumps were analyzed for gamma-emitting radionuclides. Many of these clumps were missing one or more filters due to the increased, but incomplete, sampling frequency. The air volumes for the 5/11 through 5/14 clumps are much smaller than normal because of the short sampling time (Table A7). No filter was included in more than one clump. In addition, the gamma analytical results for clumps were not combined to calculate concentrations for the biweekly 5/22 sample period.

\section{Radiochemical Analyses}

Under normal sampling conditions, individual AIRNET filters are measured for gross alpha and gross beta activities by front face counting. These filters are also grouped together as clumps for gamma spectroscopy measurements. After these analyses are complete for a calendar quarter of samples, half of each filter from the six or seven sampling periods at each site is used to prepare a quarterly composite for each AIRNET station. These composites are dissolved, separated chemically, and then analyzed for isotopes of americium, plutonium, and uranium using alpha spectroscopy.

As noted previously, the normal sampling period for an AIRNET sample is two weeks. However, during the fire, samples were collected and analyzed more frequently. To evaluate potential human exposure to air contaminants, the May samples were analyzed as soon as possible and for additional specific radionuclides. Some samples were only collected for a day and then analyzed for both the two-week and quarterly composite suite of analyses. Table 2 compares the AIRNET analyses had the fire not occurred versus the analyses that did occur.

With the exception of the gamma spectroscopy measurements that are listed as "less than" values, all radiochemical analyses supplied by the contract laboratory also include the 2s (2 standard deviations or 2 sigma) analytical and blank correction uncertainties. Air concentrations greater than their 3s uncertainties are used to identify samples with detectable concentrations. Other multiples of uncertainties could be used, but 3s is consistent with the widely accepted practice of using 3s control limits for statistical quality control charts (Duncan 1986 and Gilbert 1987). This choice also eliminates most false positives or detections, which occur about $5 \%$ of the time at $2 \mathrm{~s}$, but less than $0.3 \%$ of the time at $3 \mathrm{~s}$. 
Table 2. Comparison of AIRNET 'Normal' and Fire-Related Analysis

\begin{tabular}{|c|c|c|}
\hline Analysis & Normal & Fire \\
\hline Gross alpha/beta activity & $\begin{array}{l}5 / 8 \text { and } 5 / 22 \text { biweekly } \\
\text { filters }\end{array}$ & $\begin{array}{l}>5 / 8 \text { biweekly filters } \\
>5 / 11,5 / 12,5 / 13,5 / 14 \text {, and } 5 / 22 \\
\text { short-term filters }\end{array}$ \\
\hline Gamma spectroscopy & $\begin{array}{l}5 / 8 \text { and } 5 / 22 \text { biweekly } \\
\text { clumps of filters }\end{array}$ & $\begin{array}{ll}> & 5 / 8 \text { biweekly clumps of filters } \\
> & 5 / 11,5 / 12,5 / 13,5 / 14, \text { and } 5 / 22 \\
& \text { short-term clumps of filters }\end{array}$ \\
\hline Isotopic Analyses & $>$ Quarter 2 composites & $\begin{aligned}> & 5 / 8 \text { biweekly filters } \\
> & 5 / 11,5 / 12,5 / 13 \text {, and } 5 / 14 \text { short- } \\
& \text { term analyses } \\
> & \text { Quarter } 2 \text { composites }\end{aligned}$ \\
\hline
\end{tabular}

Comparing short-term measurements to long-term measurements can lead to erroneous conclusions because of natural variability in concentrations over time and uncertainties of sampling and analytical processes. Short-term concentrations have the potential to be significantly higher or lower than long-term concentrations. Uncertainties are strongly related to the analytical process and to the amount of material present on the filter. Consequently, dramatic reductions in sampling time, and therefore sampled air volumes, will greatly increase the uncertainty of the calculated air concentrations because the analytical results will be attributed to fewer cubic meters of air (Figure 8). Therefore, data comparisons for this paper are generally for similar sampling times and comparable uncertainties. Any comparisons between samples with disparate sampling times or air volumes will explicitly include a measure of uncertainty, normally $3 \mathrm{~s}$, in some manner.

All of the AIRNET concentrations and uncertainties are net concentrations and net uncertainties. The net air concentrations, or blank-corrected data, include corrections for the radioactivity from the filter material and from the analytical process. Net concentrations are usually lower than concentrations without blank corrections because small amounts of radioactivity are present in filter material, acids used to dissolve the filter, and tracers added to determine recovery efficiencies. This effect was most apparent for the americium-241 measurements where most air concentrations were comparable to their 3s uncertainties because the analytical plutonium tracer contains small amounts of americium-241 (Figure 9). Data do not include any adjustment or correction for background concentrations in the environment. Some air concentrations indicate negative concentrations of radionuclides in the ambient air, which is, of course, impossible. However, it is possible for a measured concentration to be negative because the measured concentration is a sum of the true value, the blank correction, and all random errors.

Table 3 summarizes air concentration tables presented in the Appendix by analyte and by time period. Time periods are 'short term' (less than two weeks), 'biweekly,' and 'quarterly.' Tables listed in the 'All Concentrations' column include all measured concentrations even if they are less than their uncertainties because they still represent the best estimate of the air concentration. 


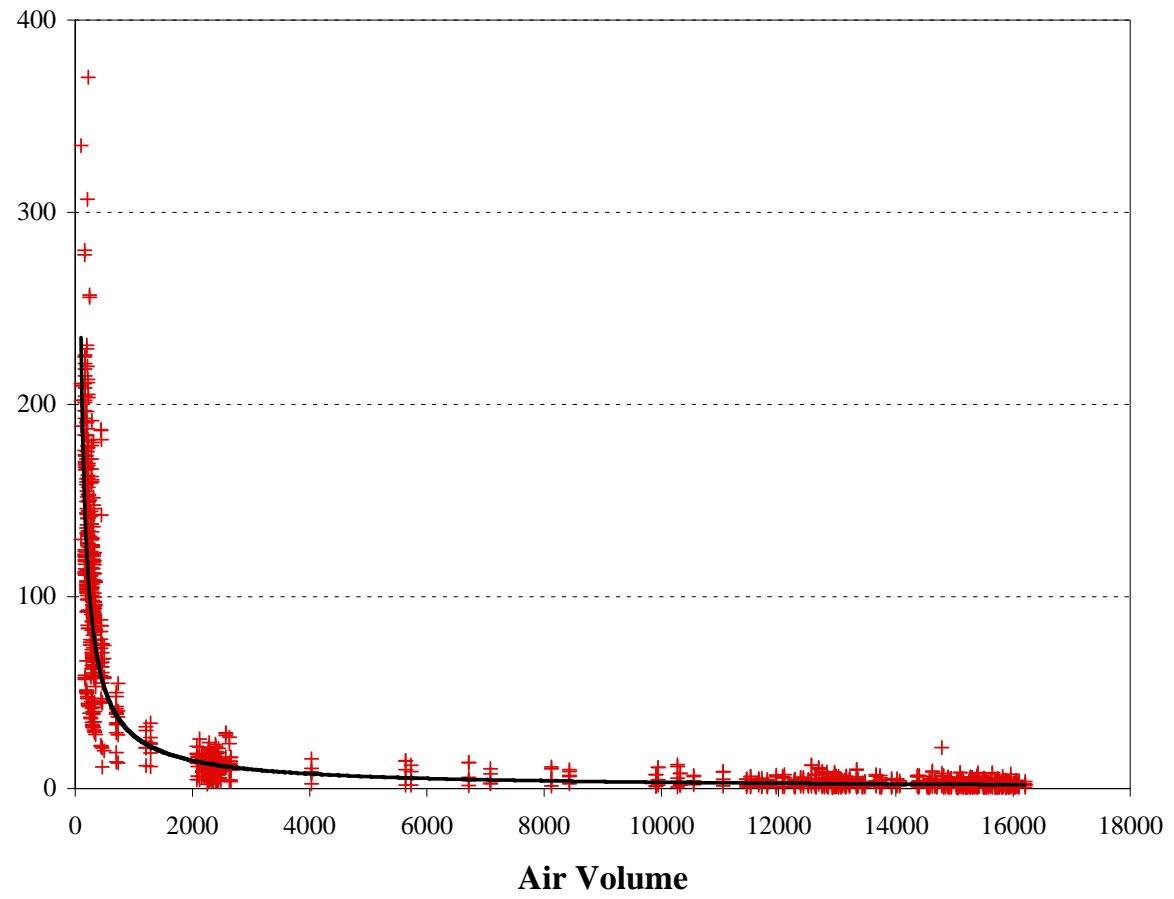

Figure 8. The effects of sampled uranium, plutonium, and americium uncertainties.

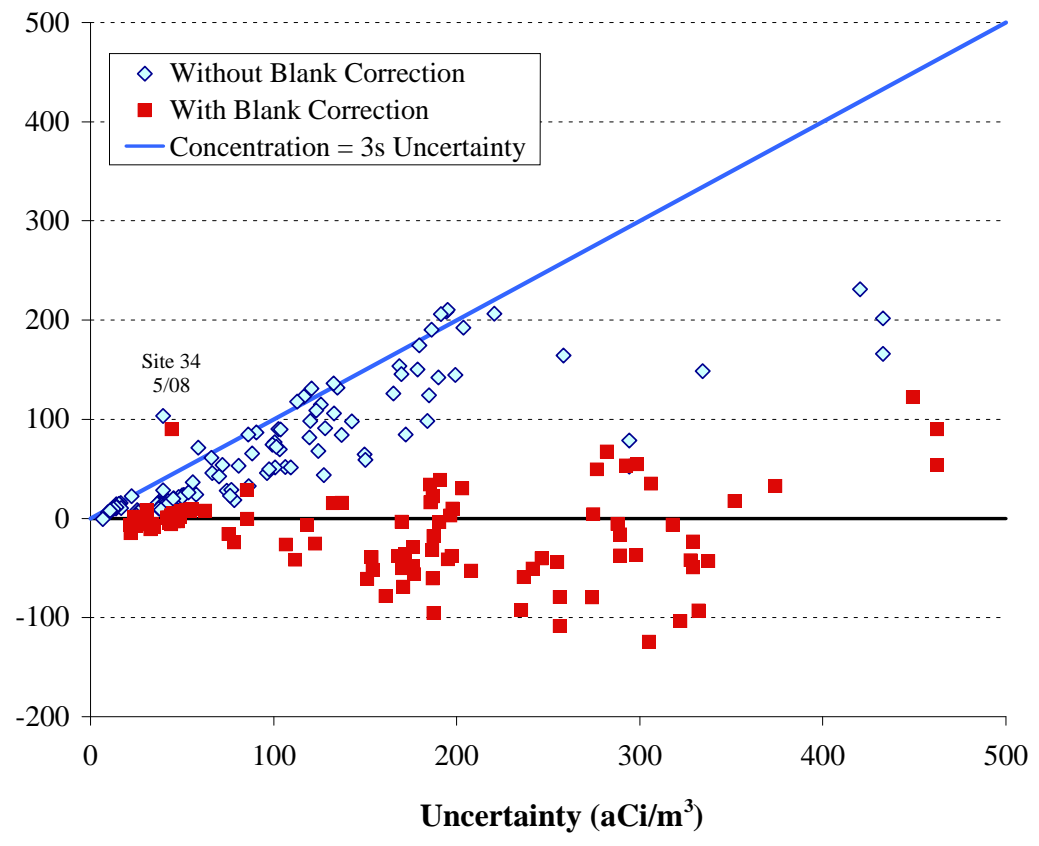

Figure 9. Americium-241 concentrations before and after blank corrections. 
Table 3. Air Concentration Appendix Tables by Analytes and Time Period

\begin{tabular}{|c|c|c|c|c|}
\hline \multirow[t]{2}{*}{ Analyses } & \multirow[t]{2}{*}{ Time Period } & \multicolumn{3}{|c|}{ Table for: } \\
\hline & & $\begin{array}{c}\text { All } \\
\text { Concentrations }\end{array}$ & Uncertainties & $\begin{array}{c}\text { Detections } \\
\text { (greater than 3s) }\end{array}$ \\
\hline \multirow{2}{*}{$\begin{array}{l}\text { Gross alpha } \\
\text { activity }\end{array}$} & short term & A-8 & A-8 & A-10 \\
\hline & biweekly & A-11 & A-11 & A-13 \\
\hline \multirow{2}{*}{$\begin{array}{l}\text { Gross beta } \\
\text { activity }\end{array}$} & short term & A-9 & A-9 & A-10 \\
\hline & biweekly & A-12 & A-12 & A-13 \\
\hline $\begin{array}{l}\text { Gamma } \\
\text { spectroscopy } \\
\text { measurements }\end{array}$ & $\begin{array}{l}\text { biweekly and } \\
\text { short term }\end{array}$ & --- & A-14 & A-15 \\
\hline \multirow{2}{*}{ Americium-241 } & $\begin{array}{l}\text { biweekly and } \\
\text { short term }\end{array}$ & A-16 & A-16 & A-22 \\
\hline & quarterly & A-25 & A-25 & A-31 \\
\hline \multirow[t]{2}{*}{ Plutonium-238 } & $\begin{array}{l}\text { biweekly and } \\
\text { short term }\end{array}$ & A-17 & A-17 & A-22 \\
\hline & quarterly & A-26 & A-26 & A-31 \\
\hline \multirow{2}{*}{ Plutonium-239 } & $\begin{array}{l}\text { biweekly and } \\
\text { short term }\end{array}$ & A-18 & A-18 & A-22 \\
\hline & quarterly & A-27 & A-27 & A-31 \\
\hline \multirow[t]{2}{*}{ Uranium-234 } & $\begin{array}{l}\text { biweekly and } \\
\text { short term }\end{array}$ & A-19 & A-19 & A-22 \\
\hline & quarterly & A-28 & A-28 & A-31 \\
\hline \multirow{2}{*}{ Uranium-235 } & $\begin{array}{l}\text { biweekly and } \\
\text { short term }\end{array}$ & A-20 & A-20 & A-22 \\
\hline & quarterly & A-29 & A-29 & A-31 \\
\hline \multirow[t]{2}{*}{ Uranium-238 } & $\begin{array}{l}\text { biweekly and } \\
\text { short term }\end{array}$ & A-21 & A-21 & A-22 \\
\hline & quarterly & A-30 & A-30 & A-31 \\
\hline \multirow{2}{*}{$\begin{array}{l}\text { Excess isotopic } \\
\text { uranium }\end{array}$} & $\begin{array}{l}\text { biweekly and } \\
\text { short term }\end{array}$ & --- & --- & A-22 \\
\hline & quarterly & --- & --- & A-31 \\
\hline $\begin{array}{l}\text { Polonium-210 } \\
\text { and lead-210 }\end{array}$ & $\begin{array}{l}\text { biweekly and } \\
\text { short term }\end{array}$ & A-23 & A-23 & A-24 \\
\hline
\end{tabular}




\section{Gross Alpha and Gross Beta Activity}

The gross alpha and gross beta activities measured on the AIRNET filters are dominated by radon-222 decay products, which are part of the uranium-238 decay series (see Figure 1). Radon itself is not collected by the filters because it is an inert noble gas that comes from the decay of radium present in the Earth's crust, but all of its decay products are solids and therefore collected as particulate matter on the filter. The radionuclides produced in the decay chain after radon-222 and before lead-210 have half-lives that are all less than 30 minutes. Without continual replenishment from radon-222 (Figure 10), these short-lived radionuclides decay to lead-210 within a few hours after collection and are not present when the samples are analyzed one to three weeks later. However, short-lived radionuclides from radon may be present on the samples if significant radon concentrations are present in the analytical laboratories. Lead-210 is the longest-lived radionuclide in the radon-222 decay chain with a half-life of 22 years. It and its decay products, bismuth-210 and polonium-210, exist for years after the radon-222 has decayed away (Figure 11). In addition to being measured on the AIRNET filters, these three radionuclides deposit and accumulate onto other surfaces such as the forest floor, vegetation, and surface soil.

Even though the radon decay products are particulate matter, the concentrations are not normally related to concentrations of particulate matter in the atmosphere because they are derived from a gas. High wind speeds, which usually cause higher particulate matter concentrations, may actually reduce the gross alpha and gross beta concentrations because there is greater atmospheric mixing which dilutes ground level concentrations of radon-222 and its subsequent decay products. By the time the radon-222 decays, it is well mixed and regional in nature. Therefore, concentrations within a given two-week sampling period and in the same general location tend to be quite consistent. For the AIRNET sampling network, temporal variations are higher than spatial variations. However, during the Cerro Grande fire the levels of radon decay products increased and were dependent on the smoke concentrations in addition to the decay of atmospheric radon. The highly variable nature of the smoke concentrations was observed on a continuous PM-10 (particles less than 10 micrometers in diameter) monitor that was operating during the fire. It was located near the entrance to Technical Area (TA) 54. Ambient concentrations of particulate matter at this site exceeded the National Ambient Air Quality Standard of $150 \mu \mathrm{g} / \mathrm{m}^{3}$ when smoke from the fire was impacting the sampler (Figure 12).

The first data received by LANL during the Cerro Grande fire were short-term screening counts for gross alpha, gross beta, and gamma spectroscopic measurements. These counts were used to get an early indication if any releases from LANL occurred. These screening counts were later replaced by longer counts that provided more accurate measurements. Figure 13 is a graph of the gross alpha and the gross beta activities from the short-term samples collected during May 2000, the May 1999 samples, the Vivash fire in the Sangre de Cristo Mountains east of Santa Fe, New Mexico (collected by the New Mexico Environment Department [NMED] in 2000), and African fires (Lambert et al. 1991 and Le Cloarec et al. 1995). The same data are shown in Figure 14, but at greater resolution for comparison of the lower concentrations.

The May 8 samples are comparable to those from the May 1999 samples (Figures 13 and 14). The alpha and beta measurements during the Cerro Grande fire did not dramatically increase until the May 11-14 samples. The alpha concentrations increased by roughly a factor of 10 to 20 and the beta concentrations by about a factor of two to four from before the fire. The net, or 


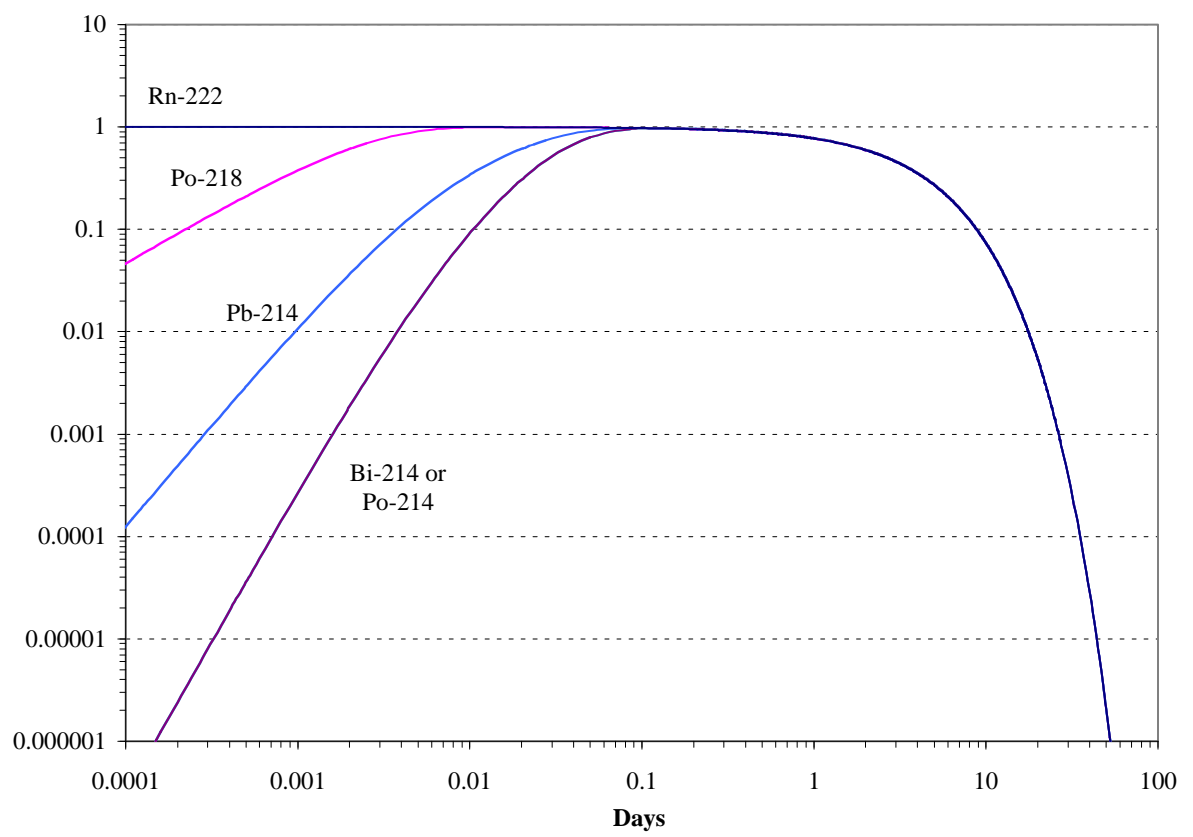

Figure 10. Radon-222 decay chain: shorter-lived radionuclides.

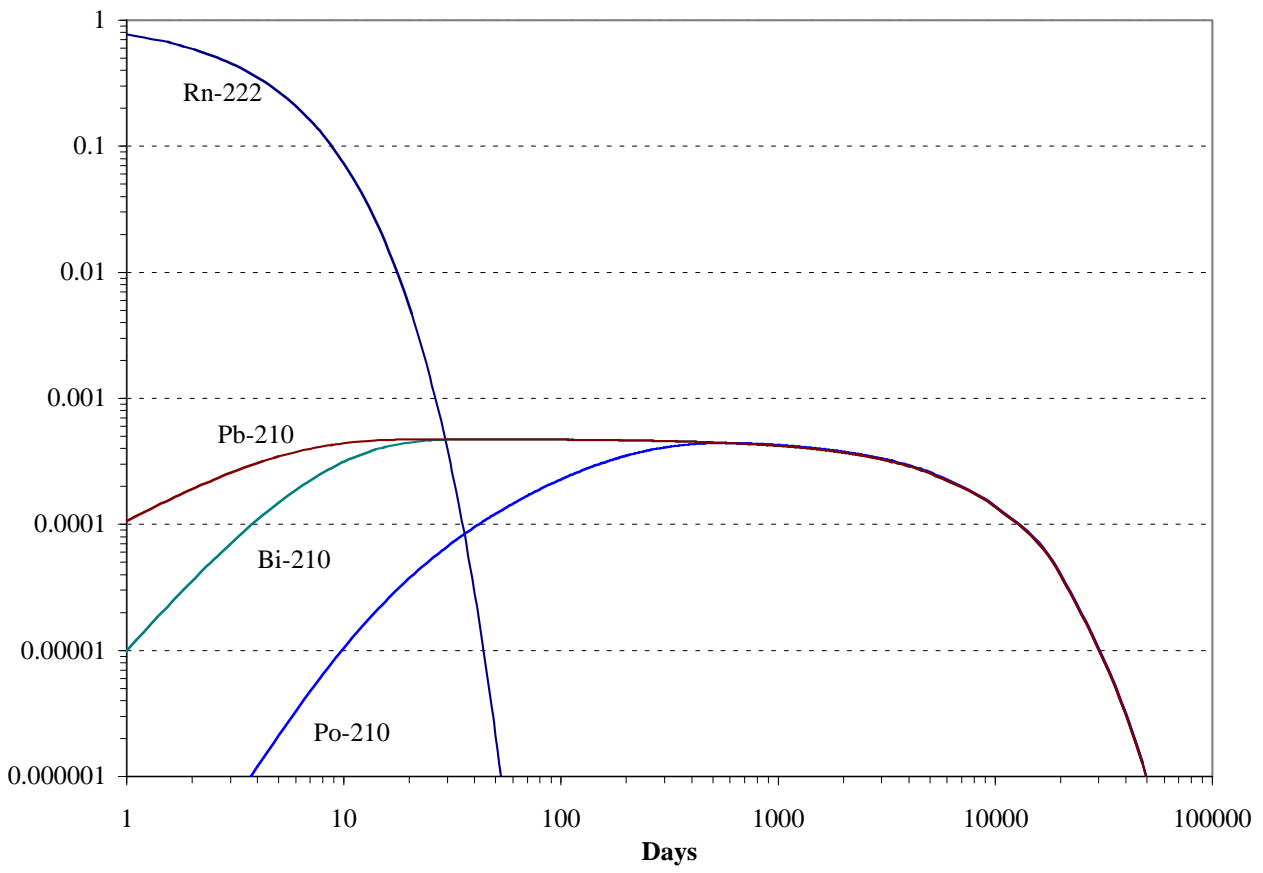

Figure 11. Radon-222 decay chain: longer-lived radionuclides. 


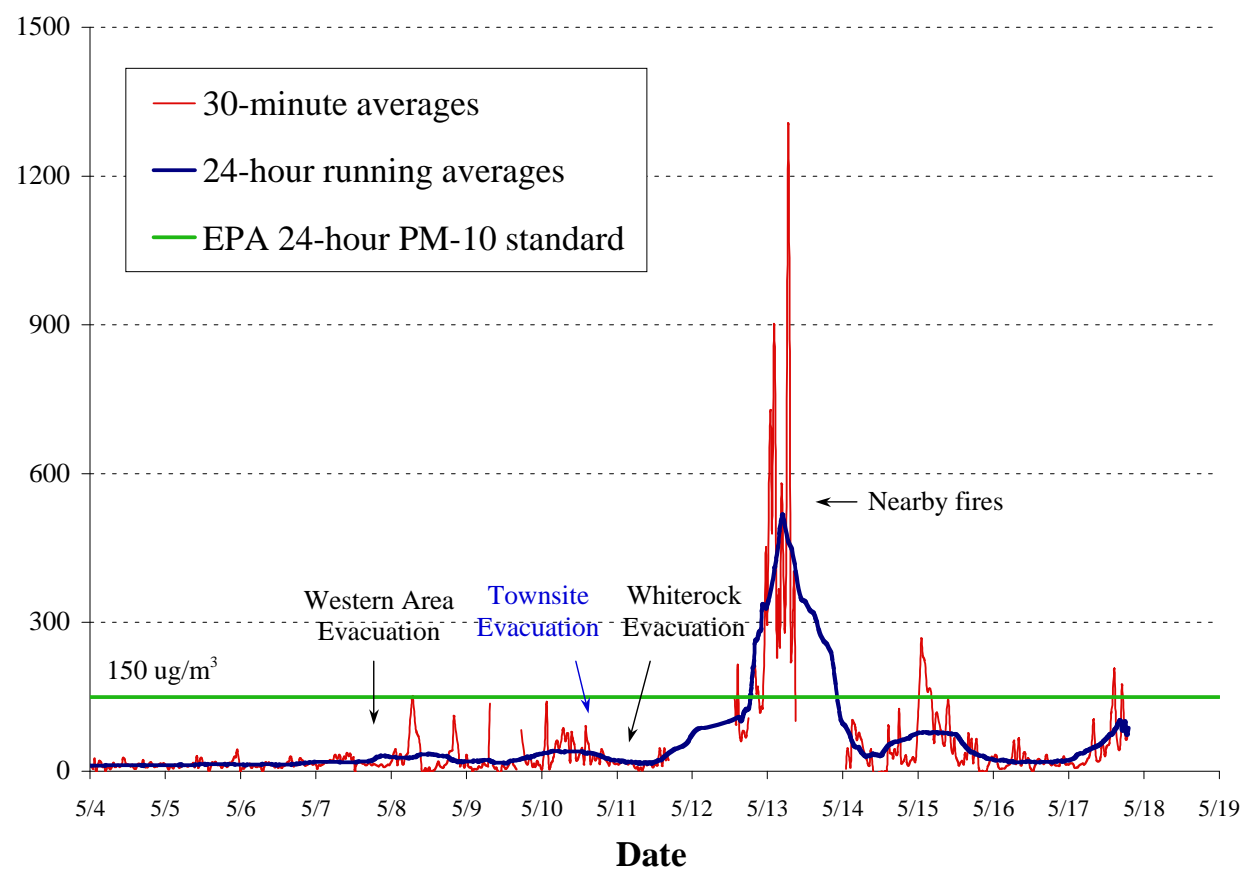

Figure 12. Particulate matter concentrations (at TA-54-1001).

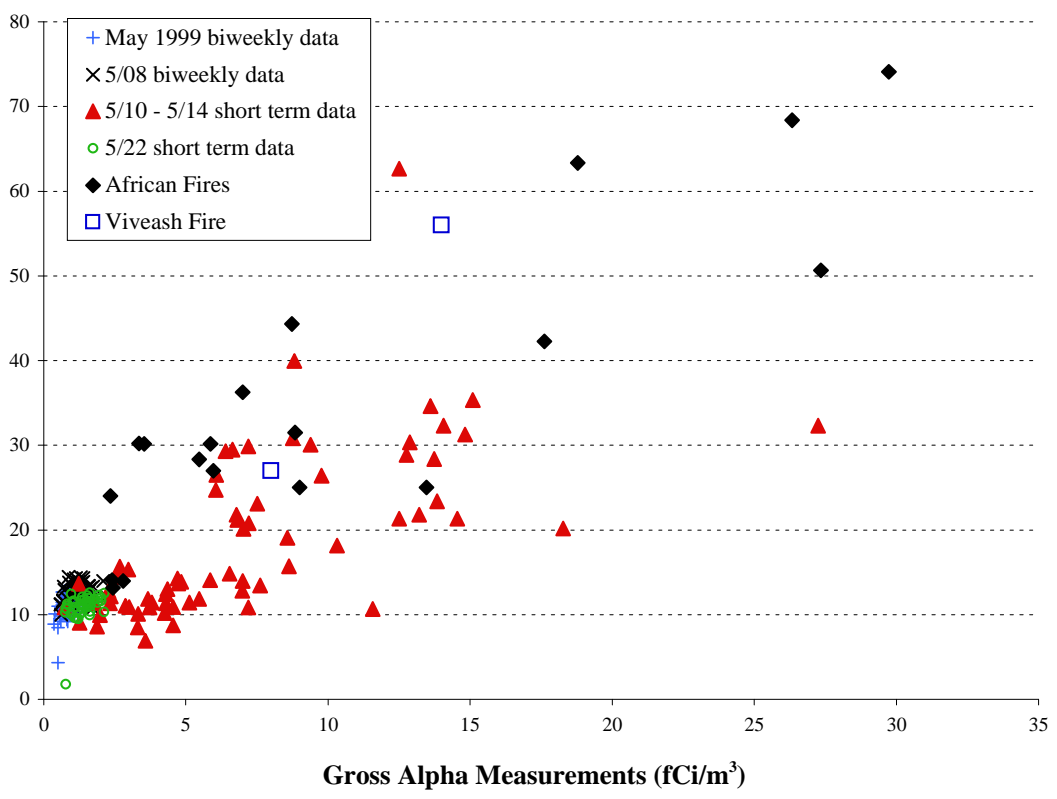

Figure 13. Gross alpha and gross beta measurements during the Cerro Grande and other fires. 


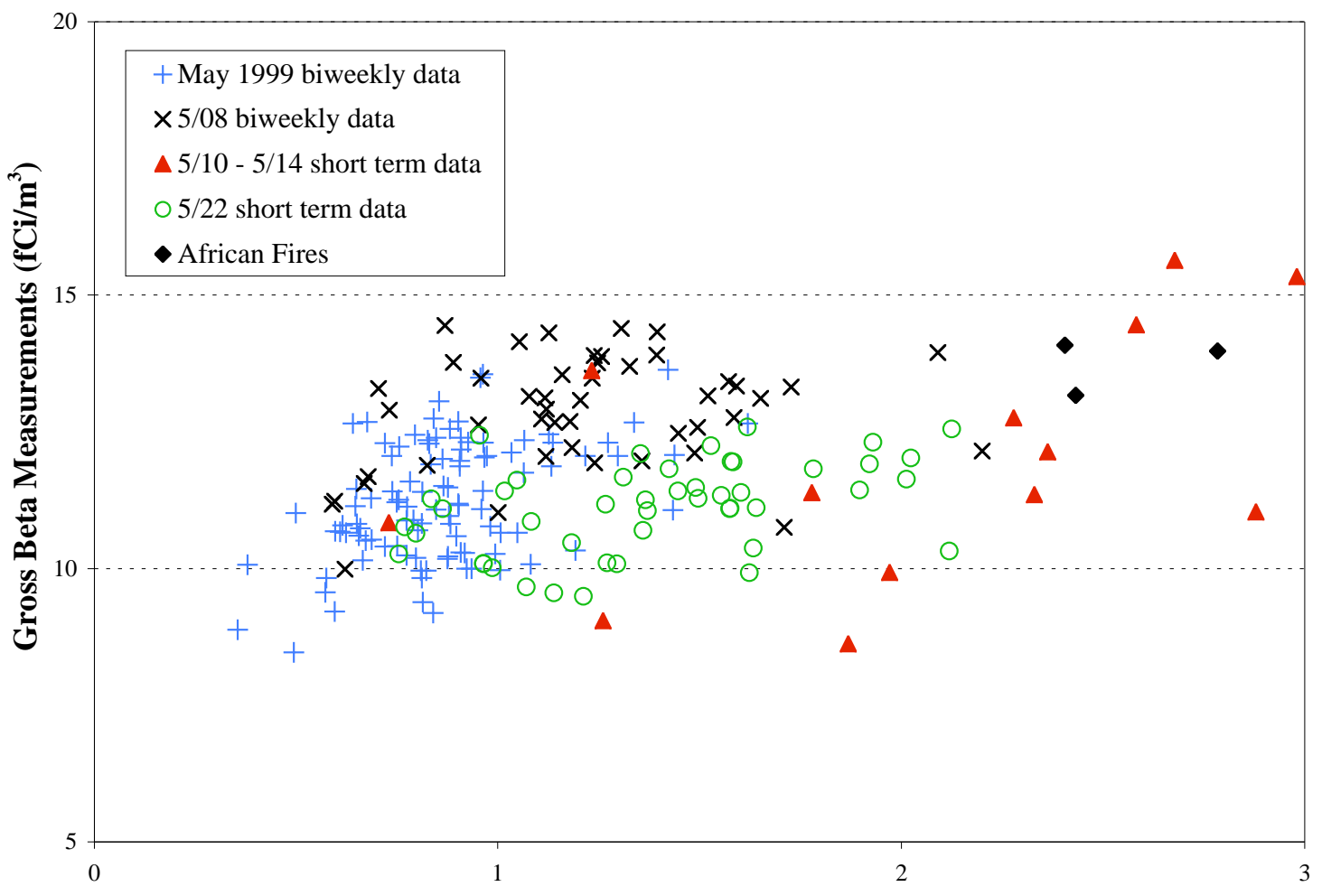

Gross Alpha Measurements $\left(\mathbf{f C i} / \mathbf{m}^{3}\right)$

\section{Figure 14. Gross alpha and gross beta measurements (at greater resolution) during the Cerro Grande and other fires.}

incremental, increase above background was somewhat similar, about 4 to $6 \mathrm{fCi} / \mathrm{m}^{3}$, for both types of radioactivity. The gross alpha and gross beta concentrations for the short-term May 22 samples are generally comparable to pre-fire concentrations and indicate a return to typical concentrations. These short-term increases in concentrations are comparable to the NMED measurements from the Vivash fire and from the African fires. Additional data from prescribed burns in northern New Mexico (Reinhardt et al. 2004) were higher than any of the measurements from these fires with alpha and beta concentrations ranging from about 100 to $9000 \mathrm{fCi} / \mathrm{m}^{3}$. These prescribed burns were not near LANL.

Biweekly gross alpha and gross beta concentrations for all sites during 2000 are shown in Figures 15 and 16. Both types of radioactivity appeared to have comparable increases during the fire (the high sites were about 4 to $6 \mathrm{fCi} / \mathrm{m}^{3}$ higher than the low sites), but the typical or "normal" alpha activity is much lower, emphasizing this increase. These comparable increases are caused by resuspension of radon decay products that had been deposited for many years on the vegetation surfaces and in the forest floor litter (see Figure 4). Since the majority of these particles are many years old, concentrations of lead-210, bismuth-210, and polonium-210 are comparable because they approach radioactive equilibrium (see Figure 11). Site-to-site variability also peaked during the fire (Figures 17 and 18) because resuspended radon decay products did not equally impact all of the sampling locations. 


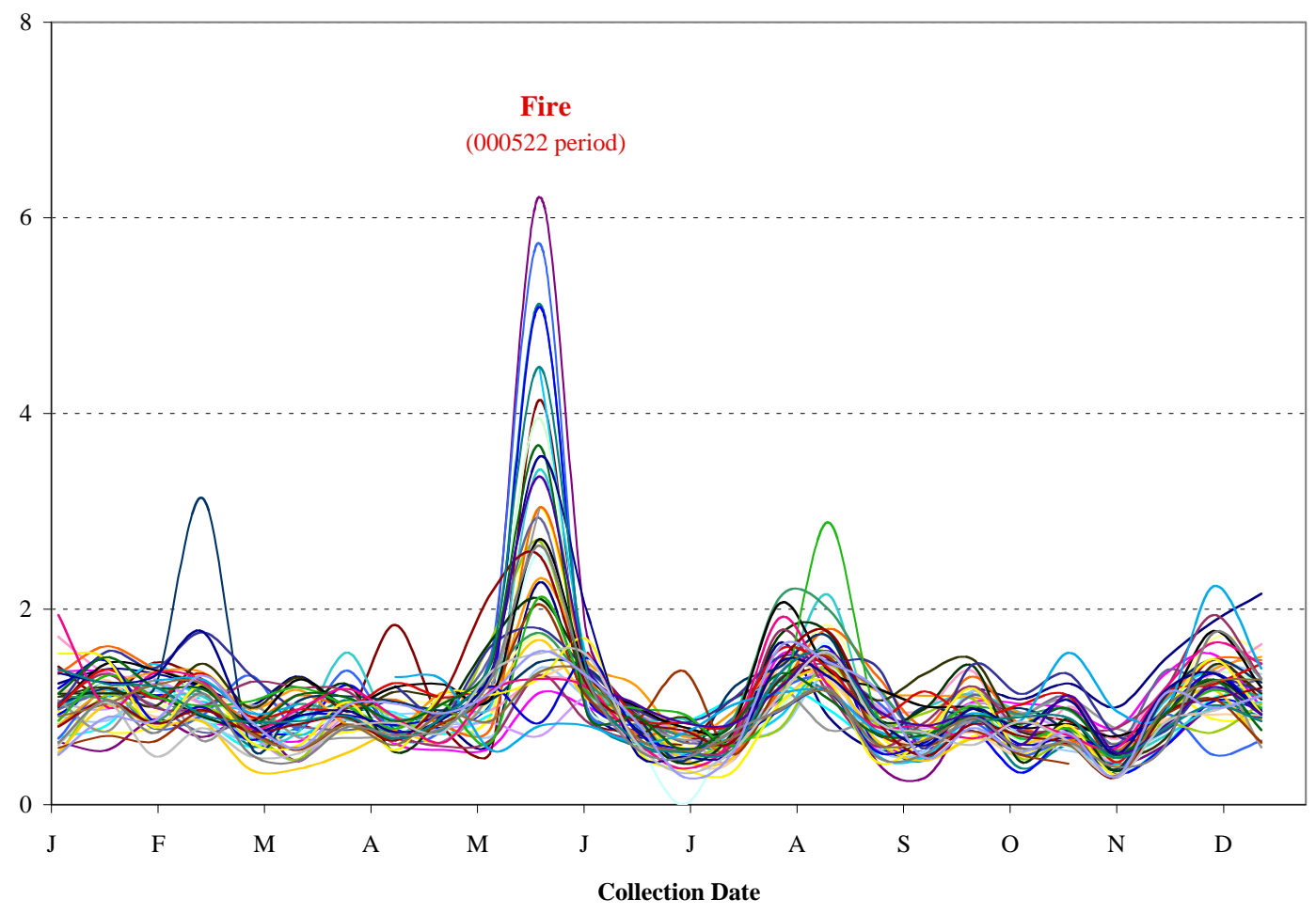

Figure 15. Biweekly gross alpha measurements by location in 2000.

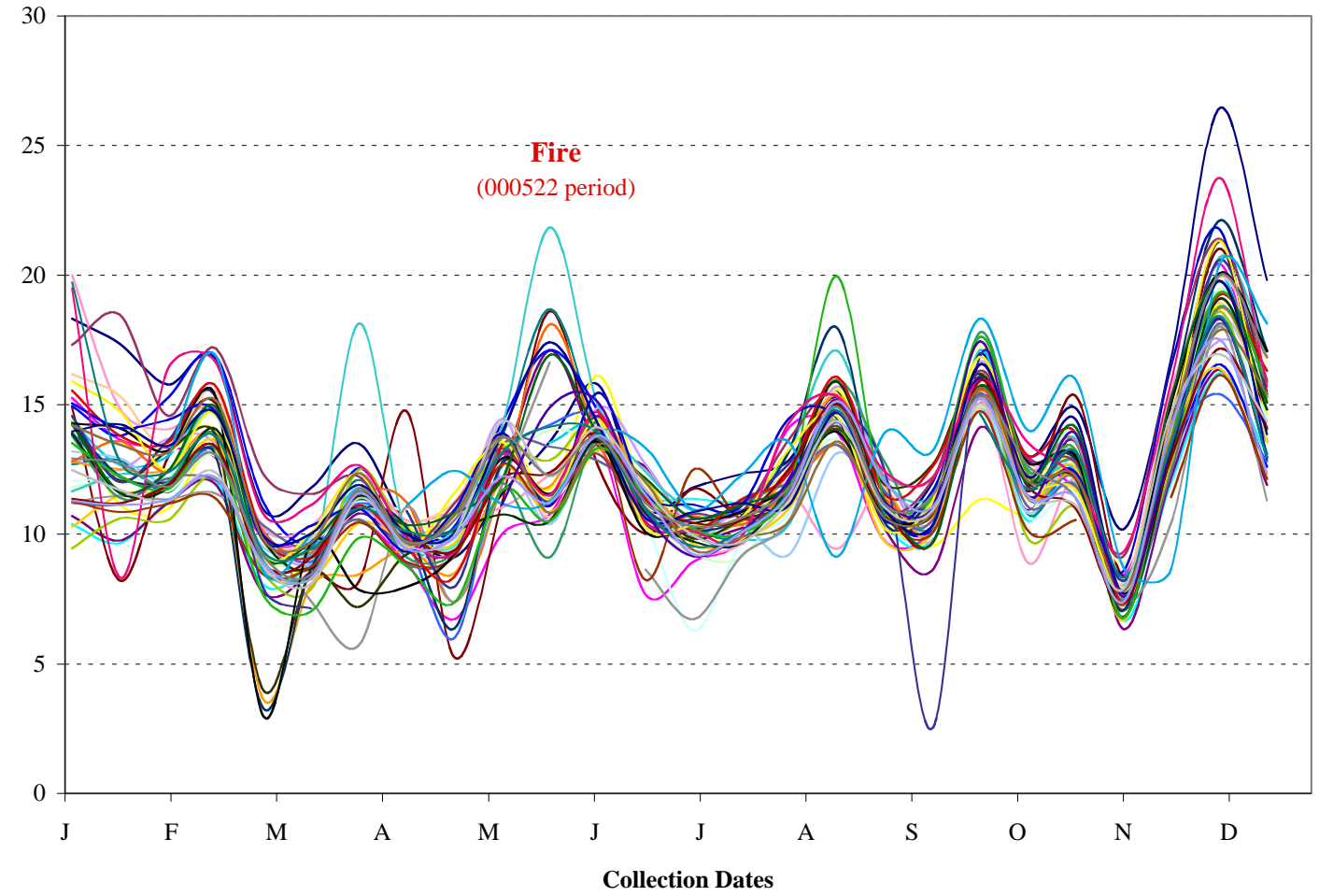

Figure 16. Biweekly gross beta measurements by location in 2000 . 


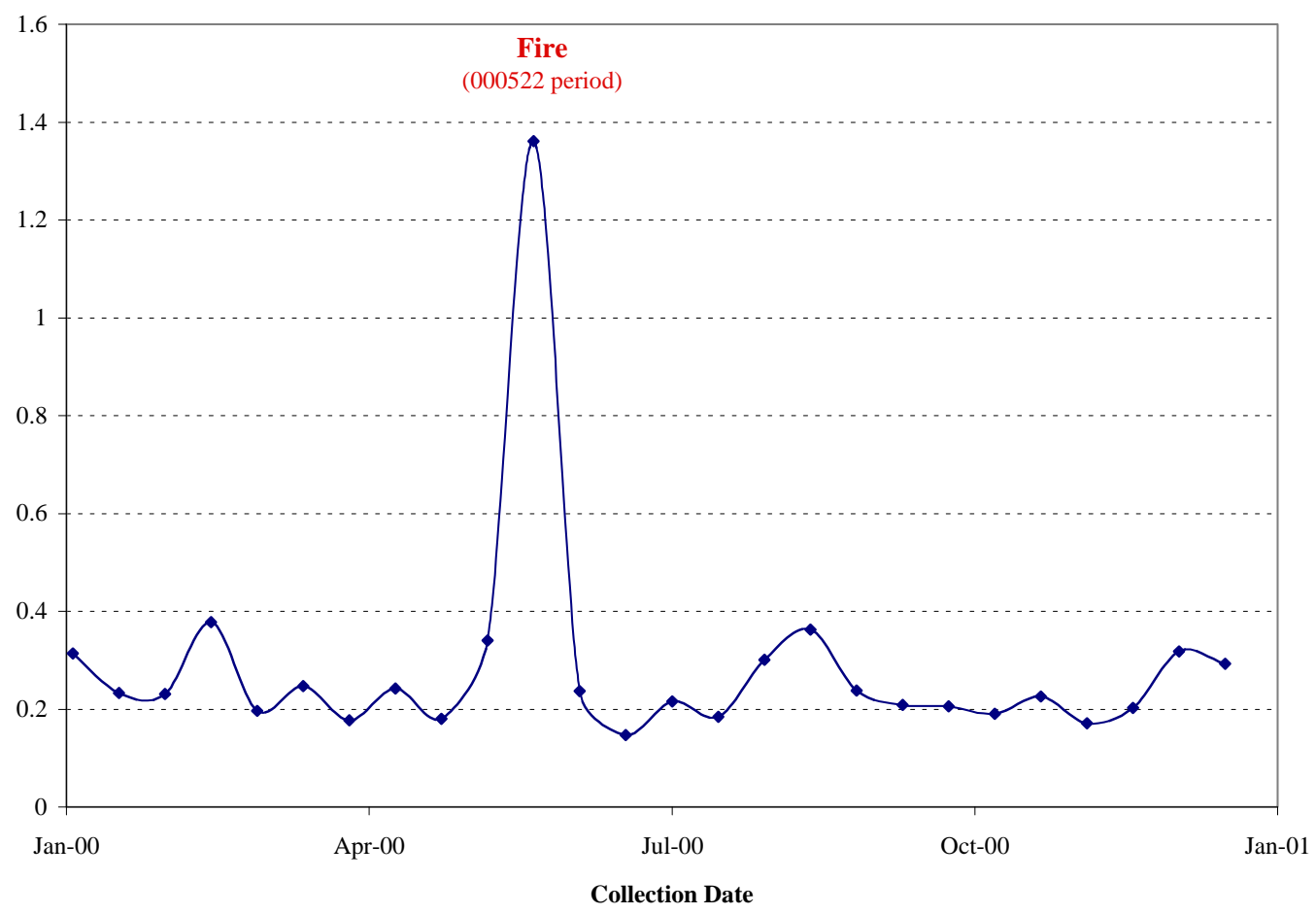

Figure 17. Biweekly gross alpha site-to-site variability in 2000.

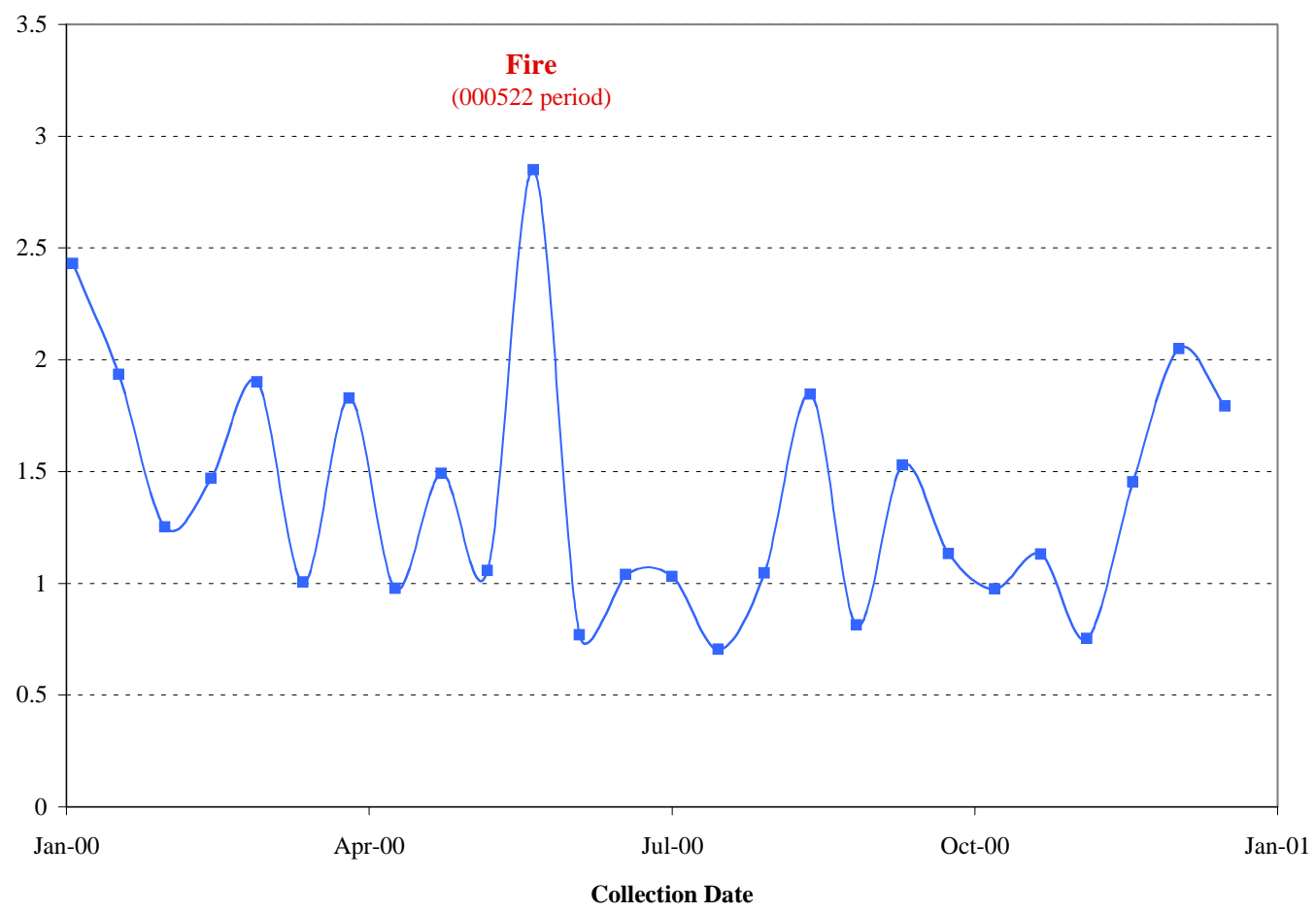

Figure 18. Biweekly gross beta site-to-site variability in 2000 . 
To compare different areas of northern New Mexico, along with the impact of the smoke from the fire, sites were grouped into one of four categories: LANL onsite, White Rock, Los Alamos town site, and Regional and Pueblo. The gross alpha and gross beta concentrations for these four groups show the largest impact of the high smoke concentrations in the Los Alamos town site and the LANL onsite groups (Figures 19 and 20). Average concentrations in White Rock and Regional and Pueblo samplers are clearly lower than the town site and onsite groups. Even though smoke impacts were observed in White Rock and other regional communities, the alpha and beta concentrations do not appear to be elevated, which indicates lower smoke concentrations. The highest individual locations in each of these four groups are shown in Figures 21 and 22. Interestingly, the Regional and Pueblo group tend to have higher alpha and beta concentrations than the other groups during non-fire periods (Figures 19 and 20). These higher concentrations may be due to the valley bottom locations where many Regional and Pueblo samplers are located. In valley bottoms there tends to be less atmospheric mixing, more sources of atmospheric radon, and more atmospheric inversions that will restrict the dispersion of particles.

As noted above, we assumed that the gross alpha and gross beta measurements represented polonium-210 and bismuth-210, respectively. However, before the fire we had not done these specific radionuclide analyses on any AIRNET filters. Therefore, a number of half-filters were analyzed for polonium-210 and lead-210. The analytical laboratory was not able to analyze for bismuth-210. Polonium-210 and lead-210 concentrations are compared to gross alpha and gross beta concentrations (Figures 23 and 24). These graphs show a direct relationship between gross alpha and polonium-210 and between gross beta and lead-210. The polonium-210 concentrations are higher than the gross alpha concentrations, but the gross alpha concentrations are calculated from front face counts, that underestimate concentrations due to burial of the alpha emitters and subsequent attenuation of the alpha particles. Gross beta activity from bismuth-210 will not be affected by burial, but it will not include the lead-210 due to its low-energy beta particles. Therefore, most of the beta activity is due to bismuth-210, which should be comparable to lead210 concentrations because it is a short-lived decay product of lead-210. Differences in the lead210 and gross beta concentrations may be due to differences in volatility during the fire, analytical uncertainty, or an unidentified beta emitter or other beta emitters suspended by the fire such as potassium- 40 .

\section{Uranium}

Three isotopes of uranium are normally found in nature: uranium-234, uranium-235, and uranium-238. Relative isotopic abundances are constant and well characterized. Uranium-238 and uranium-234 are essentially in radioactive equilibrium, with a measured uranium-238 to uranium-234 isotopic activity ratio of 0.993 (as calculated from Walker et al. 1989). Because most uranium used at LANL is either enriched (excess uranium-234 and -235) or depleted (excess uranium-238), we can use comparisons of isotopic concentrations to estimate LANL contributions to ambient air concentrations. Using excess uranium-234 to detect the presence of enriched uranium may not seem suitable because the enrichment process is usually designed to increase uranium-235 concentrations. However, enrichment normally increases uranium-234 at a faster rate than uranium-235, which makes the uranium-234 the better indicator. In addition, the dose, in natural uranium, is more than an order of magnitude higher for uranium-234 than for uranium-235 due to its much shorter half-life. Because the selected analytical process, alpha 


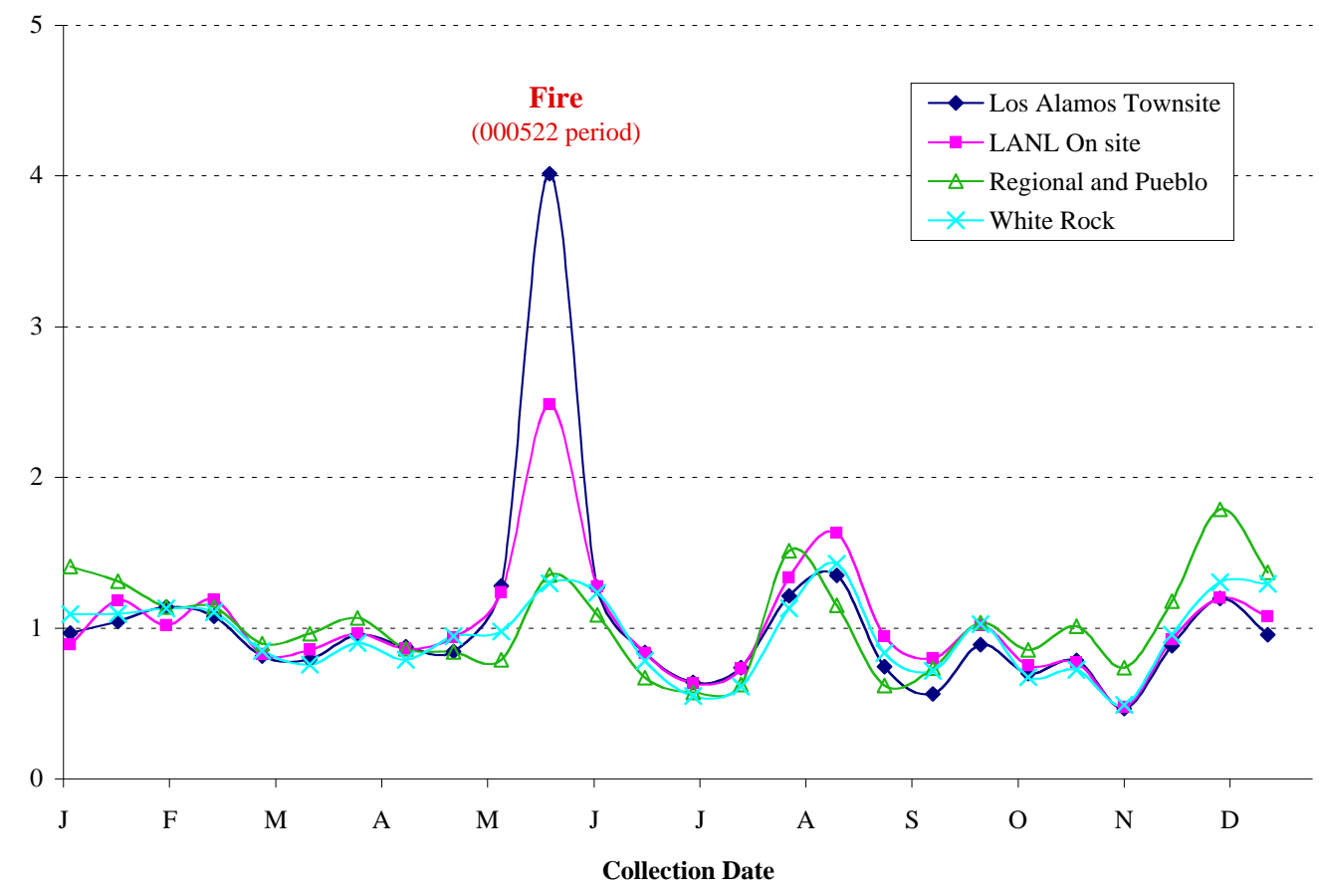

Figure 19. Biweekly gross alpha air concentrations by group for 2000 .

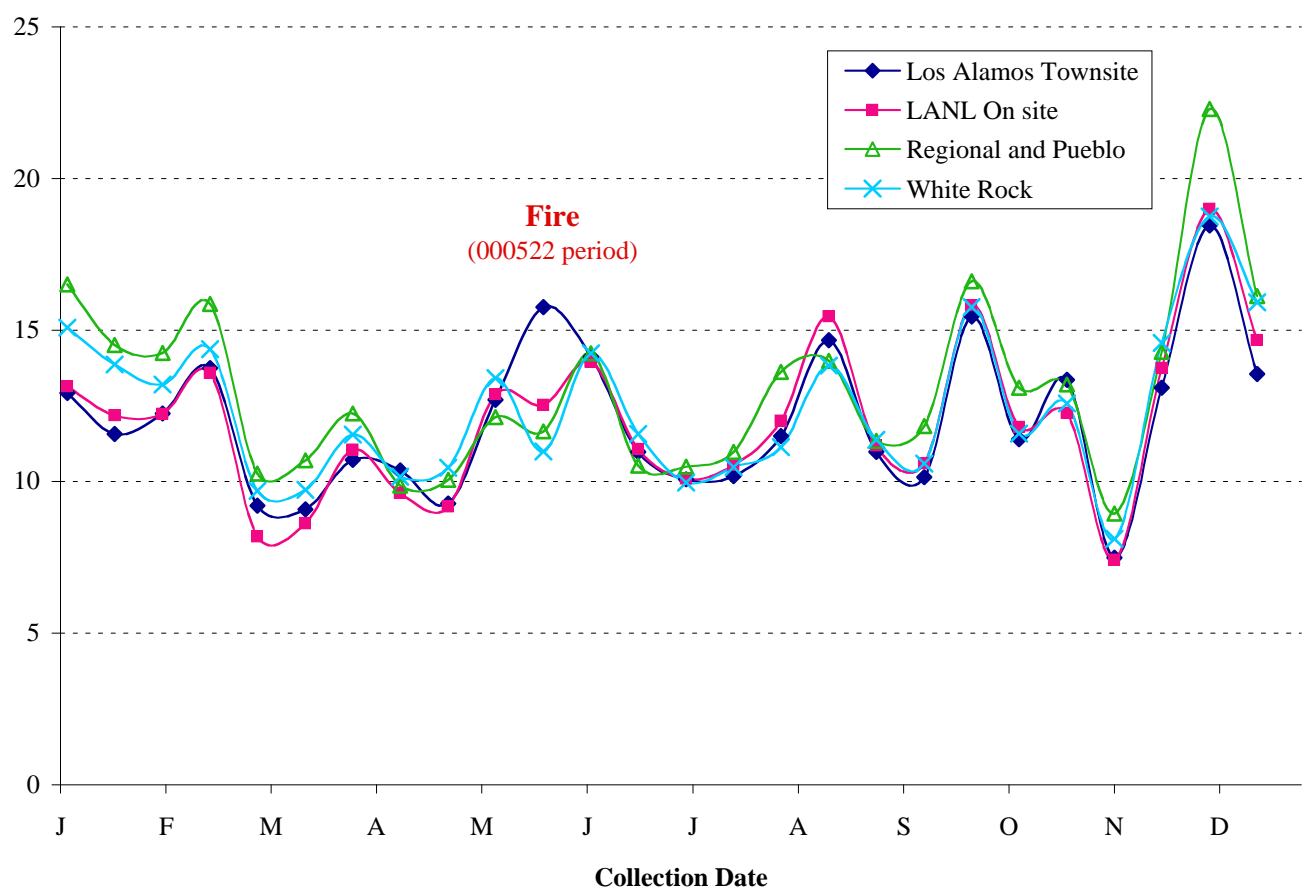

Figure 20. Biweekly gross beta air concentrations by group for 2000 . 


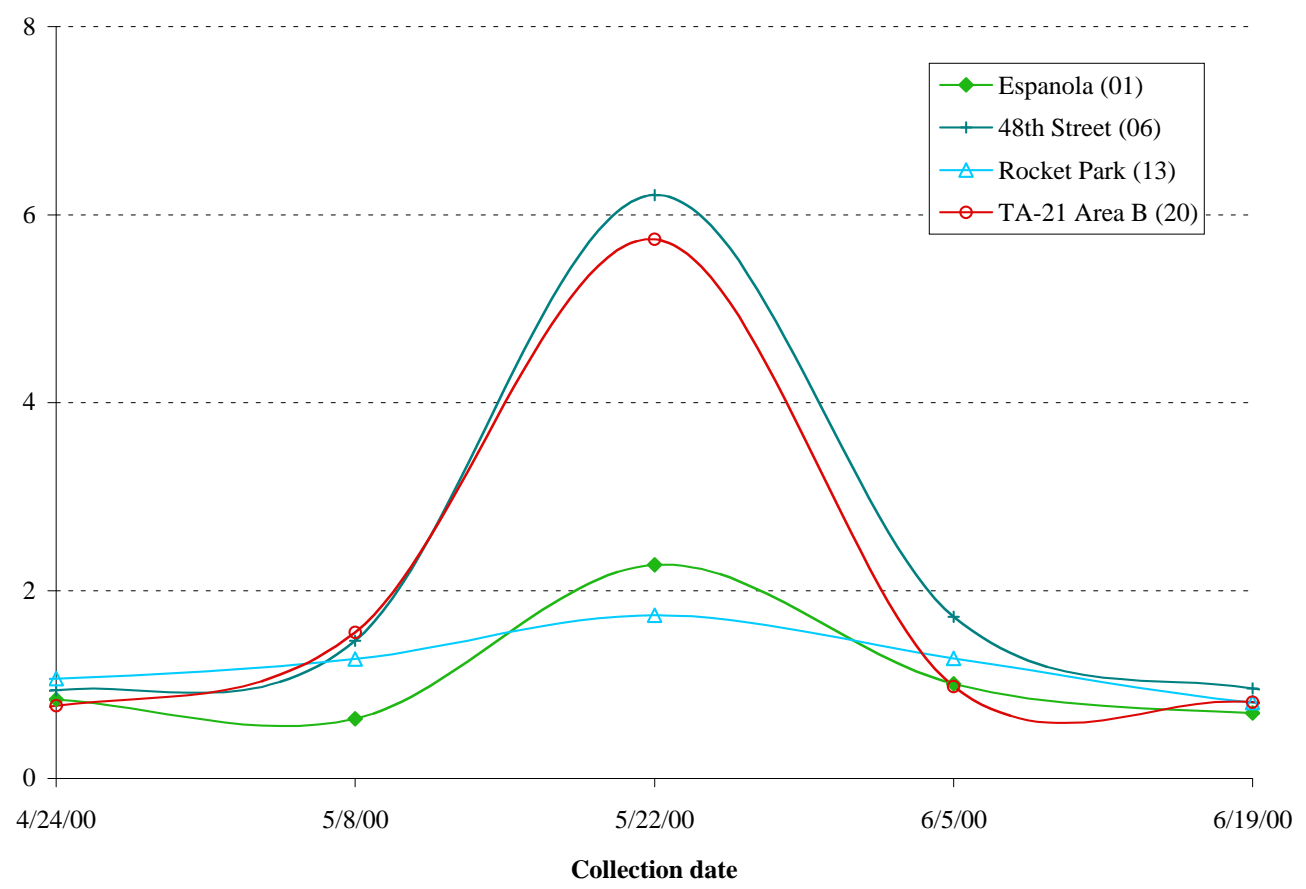

Figure 21. Biweekly gross alpha concentrations for AIRNET sites with the highest concentration in each geographic group.

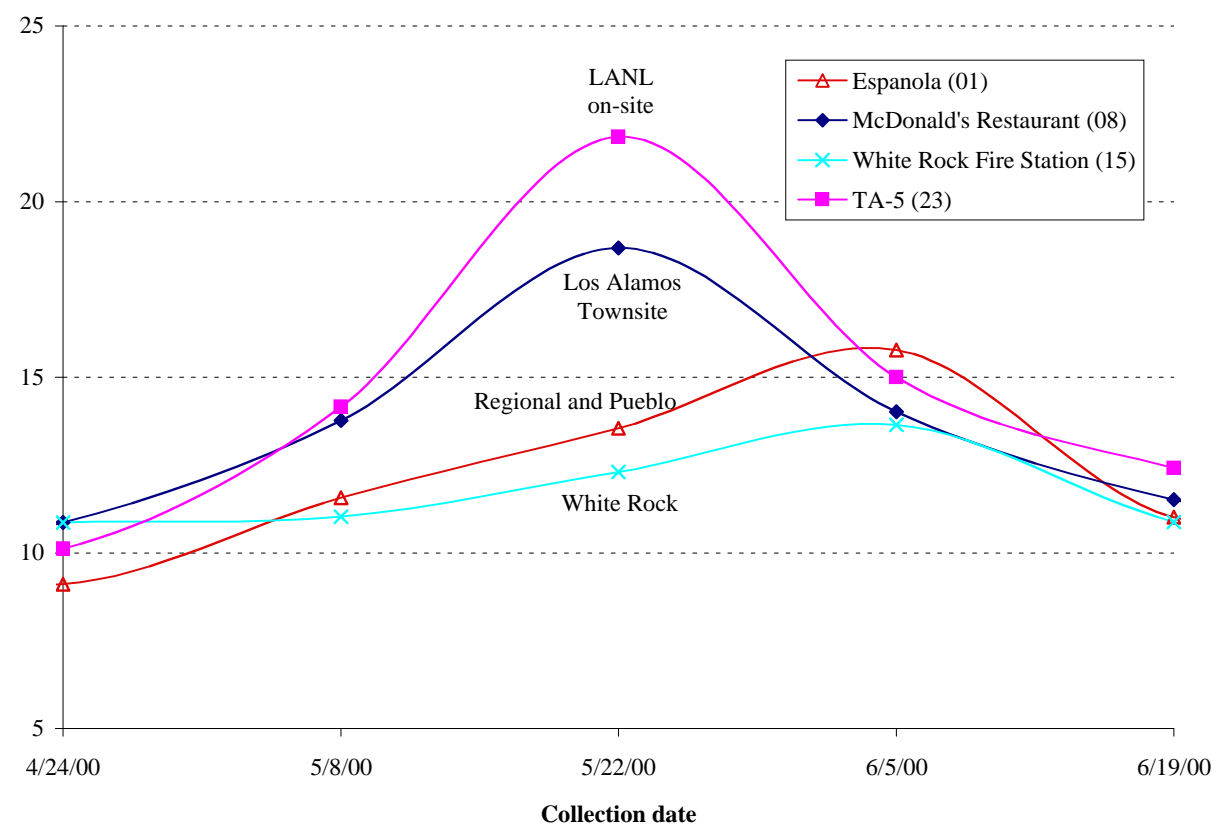

Figure 22. Biweekly gross beta concentrations for AIRNET sites with the highest concentration in each geographic group. 


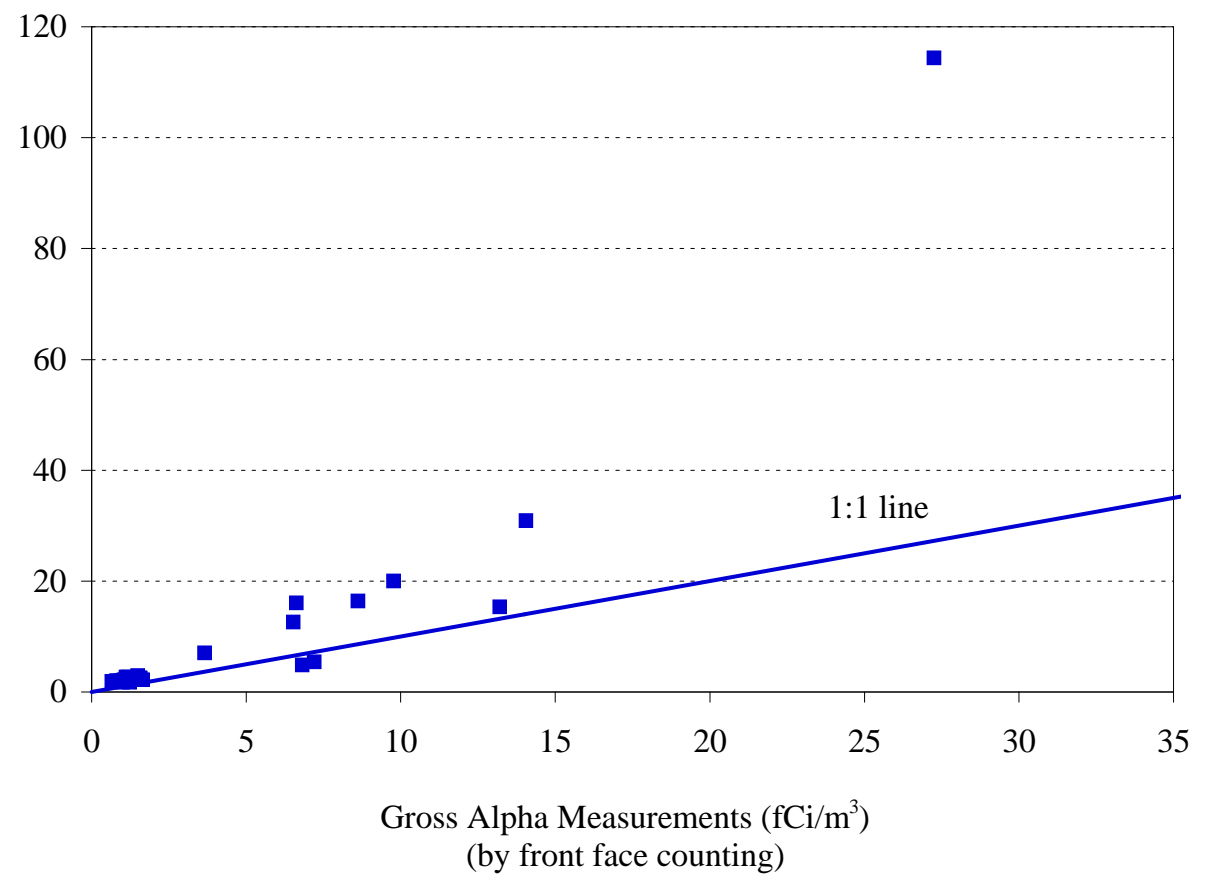

Figure 23. Gross alpha measurements versus polonium-210 measurements during the Cerro Grande fire.

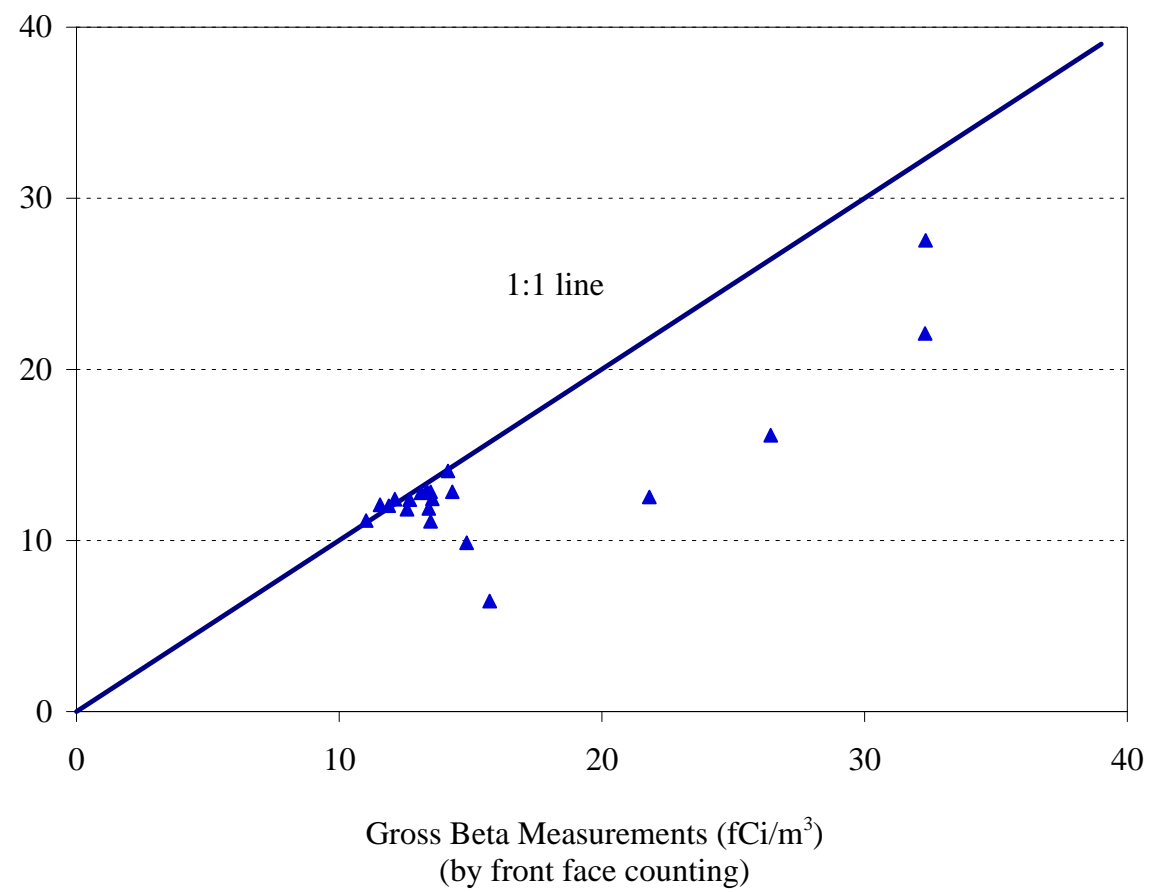

Figure 24. Gross beta measurements versus lead-210 measurements during the Cerro Grande fire. 
spectroscopy, measures radioactivity it provides better measurements of the two primary contributors to the total uranium dose (uranium-234 and uranium-238). To calculate excess isotopic uranium, the difference between the two concentrations is compared to the pooled standard deviation. If the concentrations are more than three standard deviations apart, then excess isotopic uranium is considered to be present. Using three standard deviations is consistent with standard industrial quality control processes (Duncan 1986) where the use of two standard deviations results in too many false positives.

All of the samples collected from the 5/08 sampling period through the 5/14 sampling period were analyzed for isotopes of uranium. Many of the short-term uranium measurements were above their uncertainties and much higher than the quarterly concentrations (Figure 25), but isotopic comparisons indicate that the uranium was natural except for two onsite locations, sites 23 and 30 (Table A-22). The high winds during the fire appear to be the primary causes of the high short-term concentrations. Wind speeds at $7 \mathrm{~m} / \mathrm{sec}$ or faster dramatically increase ambient concentrations of particulate matter (Whicker et al. 2001). During the second quarter of 2000, about 24\% of these high winds occurred on May 10 and May 11 based on TA-54 meteorological tower data. The expected percent to occur on these days would only be about $2 \%$. Therefore, these windy days and the physical turbulence from the fire could cause much higher concentrations of natural and depleted uranium simply by resuspending more particulate matter. Additional depleted uranium may have also been resuspended by combustion during the fire, but quarterly concentrations were not unusually high (Figure 26), indicating that physical resuspension processes were the predominant cause of the high short-term concentrations. Finally, recent wind tunnel studies of the AIRNET sampler indicate that it over-samples large particles during high winds (Rogers et al. 2000), which may have also contributed to higher measurements during the high wind conditions.

Even though the annual and quarterly concentrations of uranium isotopes vary, peak concentrations for all three isotopes occur during the second quarter of each year (Figure 27). Furthermore, since the first quarter of 1998, the uranium-238 concentrations have been consistently higher than the uranium-234 concentrations, indicating the presence of depleted uranium in some samples. During the second quarter of 2000 the network-wide concentrations of uranium-234 and uranium-238 were slightly higher than previous and subsequent second quarters indicating unusually high winds, excessively dry conditions, and/or resuspension from combustion. The station at TA-36 (77) was not included in these averages because of the persistent and known presence of depleted uranium in the samples.

Depleted uranium has usually been detected in at least one sample per quarter-most notably the first quarters of 1997, 2001, and 2002 and the fourth quarter of 2002 when significant differences (3s) were detected in about $25 \%$ or more of the samples (Figure 28). All of the samples with depleted uranium were collected on LANL property or within Los Alamos County. For the 00Q2 sampling period, six samples had excess depleted uranium, which is the same as the number for 99Q3 and much less than 97Q1. In the six years before 2001, we collected only 15 quarterly composite samples with excess uranium-238 offsite. For the three years from 2001 through 2003, 23 offsite samples with excess uranium-238 were collected. Possible contributing causes for the increased frequency of depleted uranium measurements include below-average rainfall, less vegetation and ground cover after the fire, fire mitigation activities, and/or tree thinning operations. However, it should be noted that the offsite concentrations of depleted uranium are comparable to historical natural uranium concentrations. 


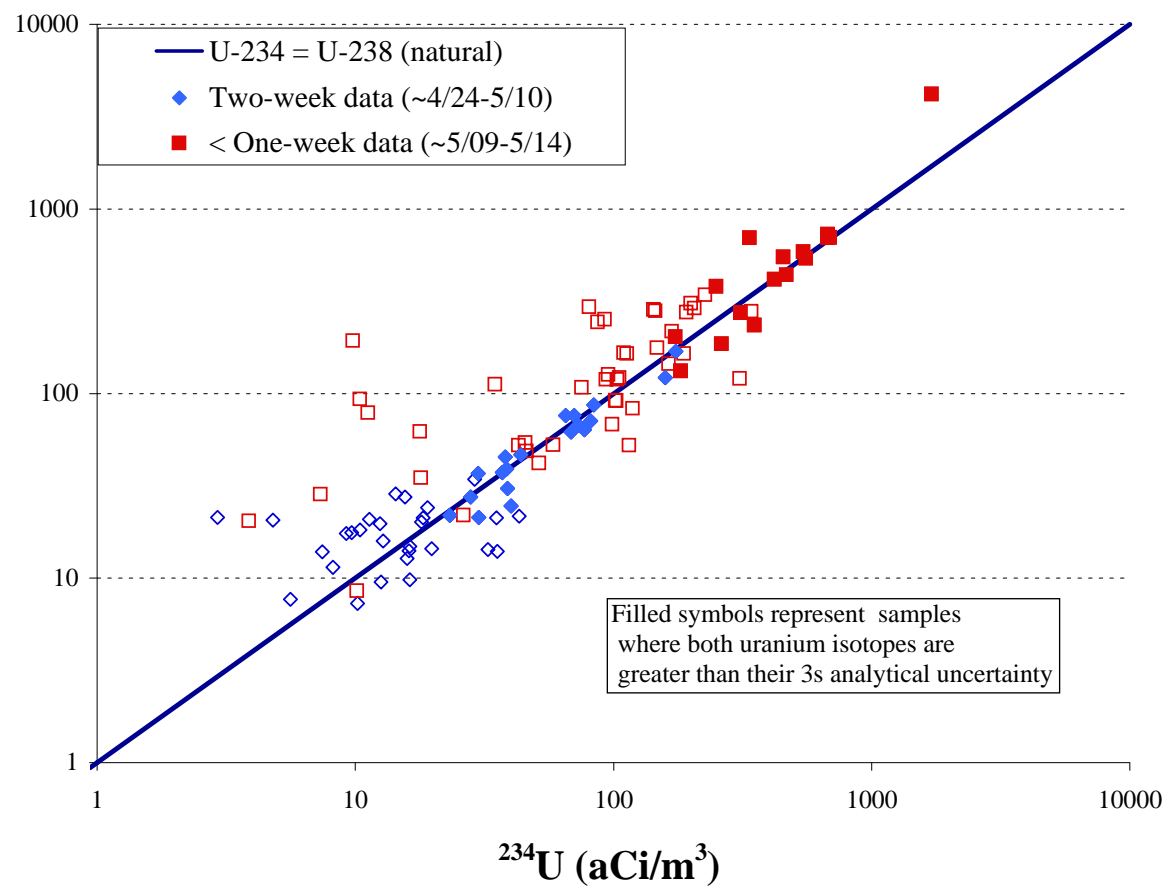

Figure 25. Short-term uranium isotopic concentrations during the Cerro Grande fire.

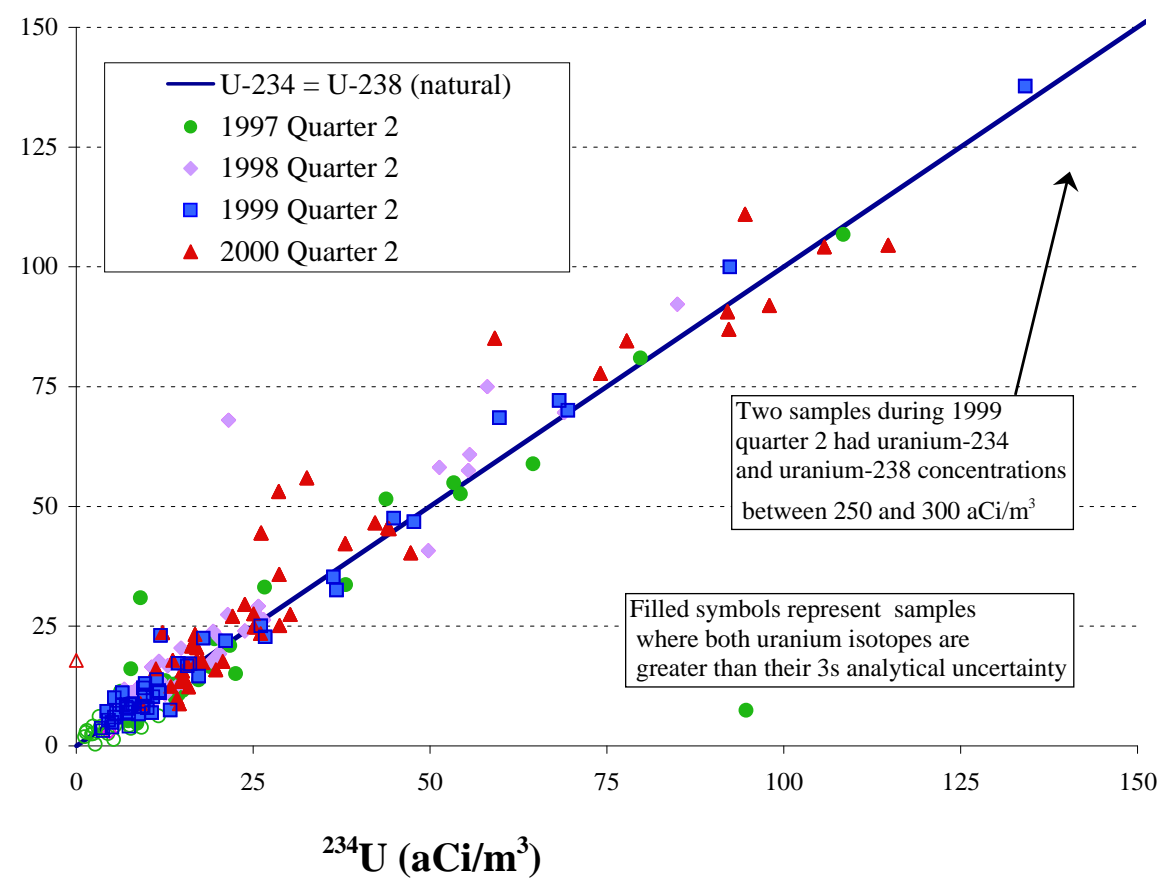

Figure 26. Quarter 2 uranium isotopic concentrations. 


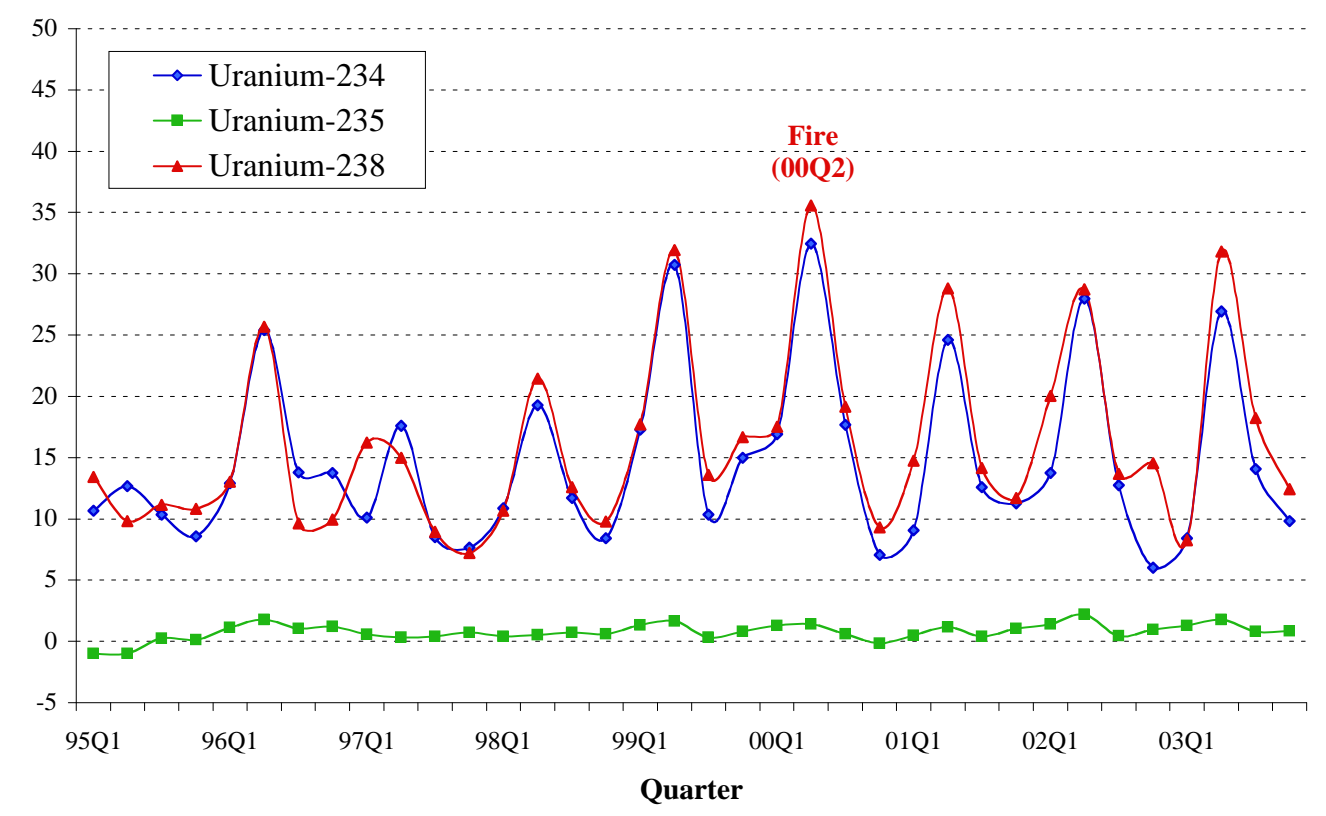

Figure 27. AIRNET quarterly uranium concentrations (network-wide concentrations excluding site 77 ).

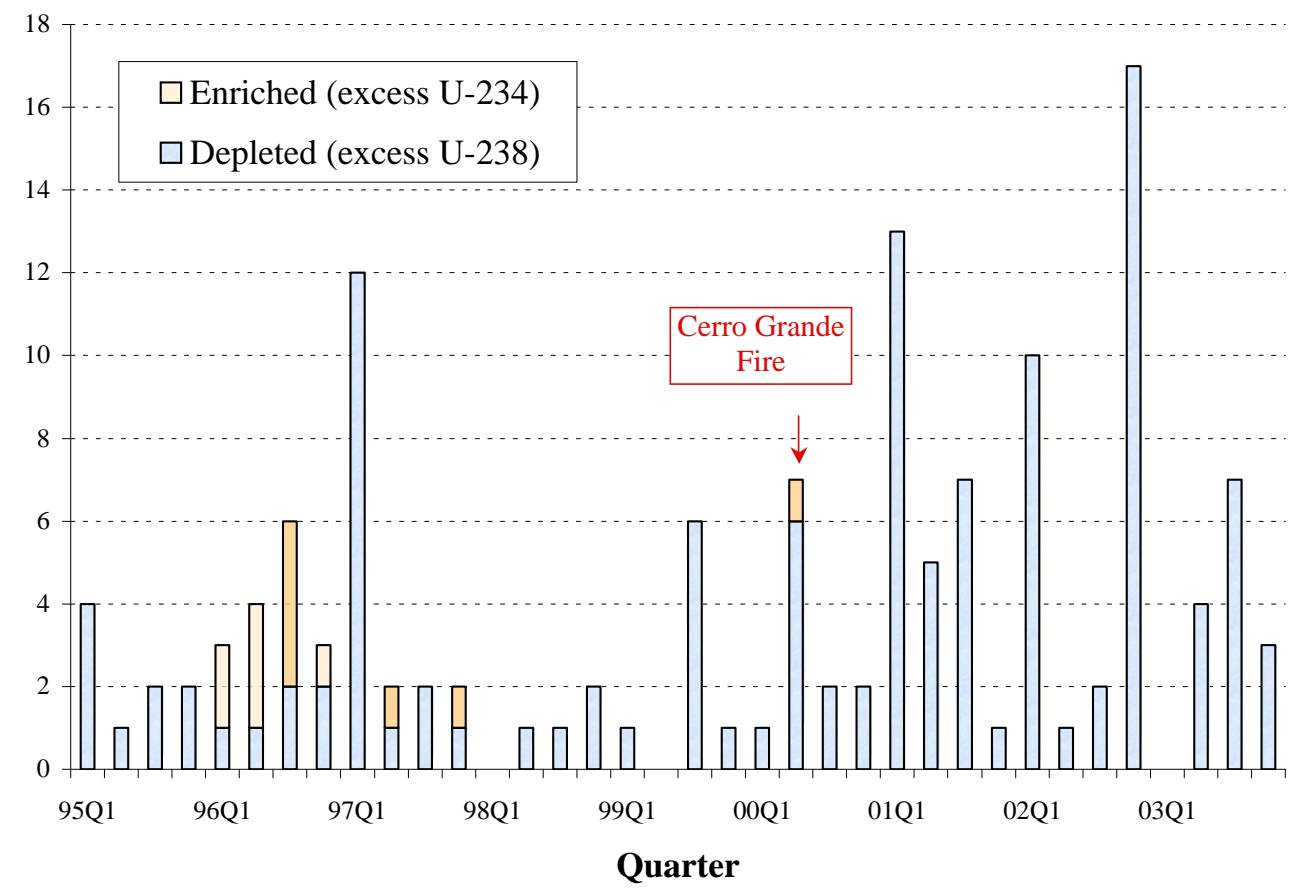

Figure 28. AIRNET sites with excess isotopic uranium. 
One 00Q2 sample from site 13 in White Rock appears to have excess enriched uranium based on the difference between the uranium-234 and uranium-238 measurements. However, the uranium234 concentration appears to be typical while the uranium-238 concentration for this sample was negative. This was the only negative uranium concentration for the year indicating a potential analytical problem.

Station 77 (Figure 29) at TA-36 is located in a posted radiation-control area where depleted uranium is still present as surface contamination. This location was previously identified as having measured excess ambient concentrations of uranium-238 (Eberhart et al. 1999; ESP 1999, 2000, and 2001). Of the 36 quarterly composites analyzed for isotopic uranium at this site, 30 have had excess uranium-238. The 00Q2 sample from this site appears to be typical. Even though the concentrations of uranium at this site are higher than other locations, they are relatively low compared to the EPA public exposure standards, which are about 20 times greater than the highest measured quarterly concentrations.

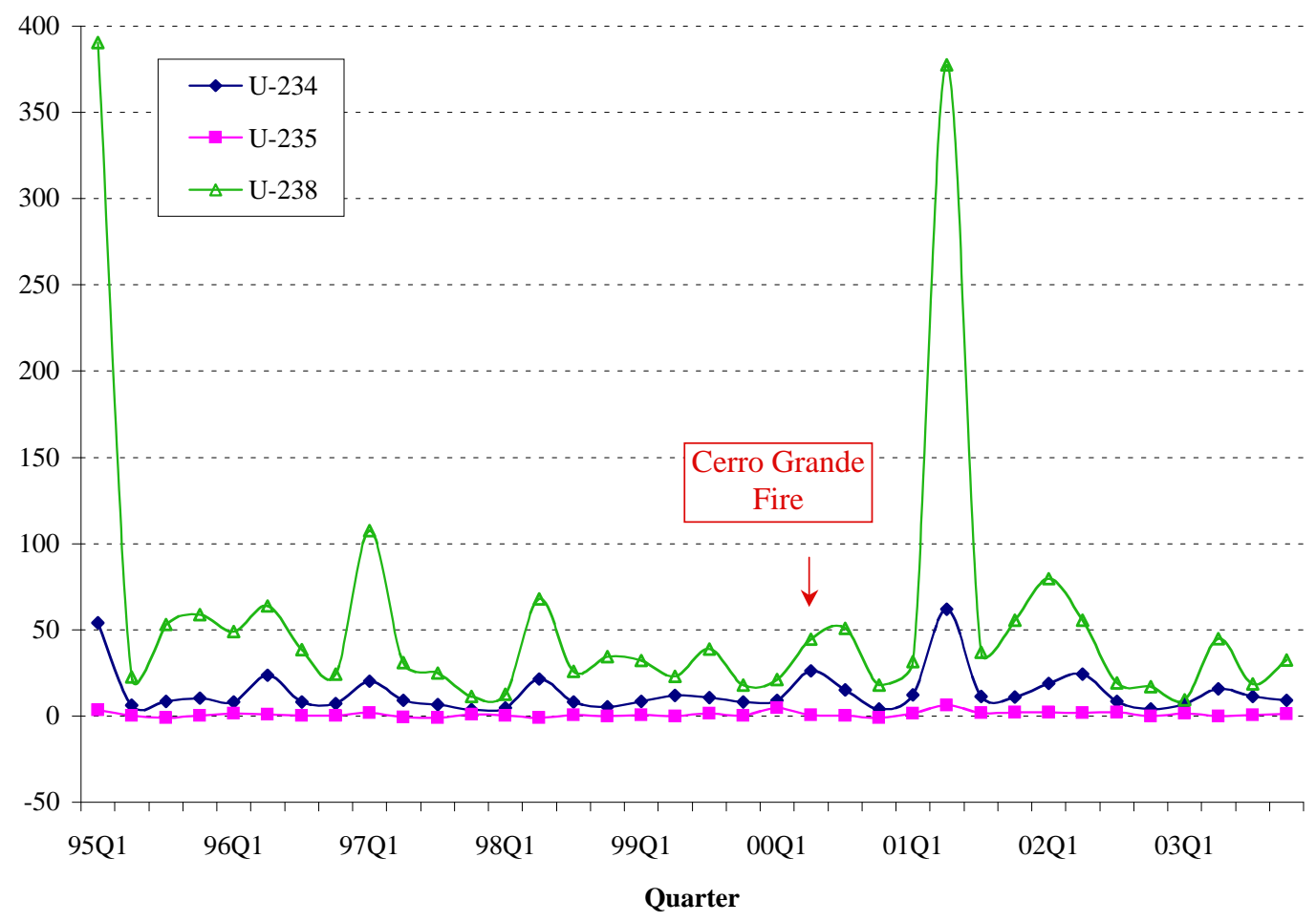

Figure 29. Site 77 uranium concentrations.

\section{Plutonium and Americium}

While plutonium and americium occur naturally at extremely low concentrations from cosmic radiation and spontaneous fission (Eisenbud and Gesell 1997), these elements are not naturally present in measurable quantities in the ambient air. All measurable sources are from plutonium research and development activities, nuclear-weapons production and testing, the nuclear fuel 
cycle, and other related activities. With few exceptions, worldwide fallout from atmospheric testing of nuclear explosives is the primary source of plutonium in ambient air.

As was the case with uranium, all of the samples collected from the 5/08 sampling period through the 5/14 sampling period were analyzed for isotopes of plutonium and americium. Calculated short-term concentrations of plutonium-238, plutonium-239, and americium-241 during the fire were more variable than historical quarterly concentrations with both higher and lower concentrations. However, only three of the biweekly and short-term plutonium and americium concentrations were greater than their 3s uncertainties (Table A-22 and Figures 30 and 31). The three samples above their 3s uncertainties were from two locations with known sources of contamination: plutonium-239 from site 66 near the former TA-1 processing area waste water outfall in the Los Alamos town site and americium-241 from site 34 in Area G. All of the other samples were below their 3s measurement uncertainties and were generally centered around zero.

Quarterly concentrations of plutonium and americium exhibited a pattern similar to the biweekly and short-term samples. Eleven measurements exceeded their 3s uncertainties (Table A-31 and Figure 32). The two americium-241 measurements and the plutonium-238 measurement above their uncertainties were from the quarterly samples for sites 27 and 34 at TA-54. The remaining eight samples had detectable concentrations of plutonium-239. Three detections were at TA-54 (sites 27, 34, and 36), three were in the Los Alamos town site (sites 07, 08, and 66), one was at TA-21 (site 20), and one was at TA-5 (site 23). All of these measurements were comparable to other measurements at these locations. The network-wide concentrations of americium-241, plutonium-238, and plutonium-239 were not elevated in the second quarter of 2000 (Figure 33) and were less than the majority of the quarterly concentrations before 2000 .

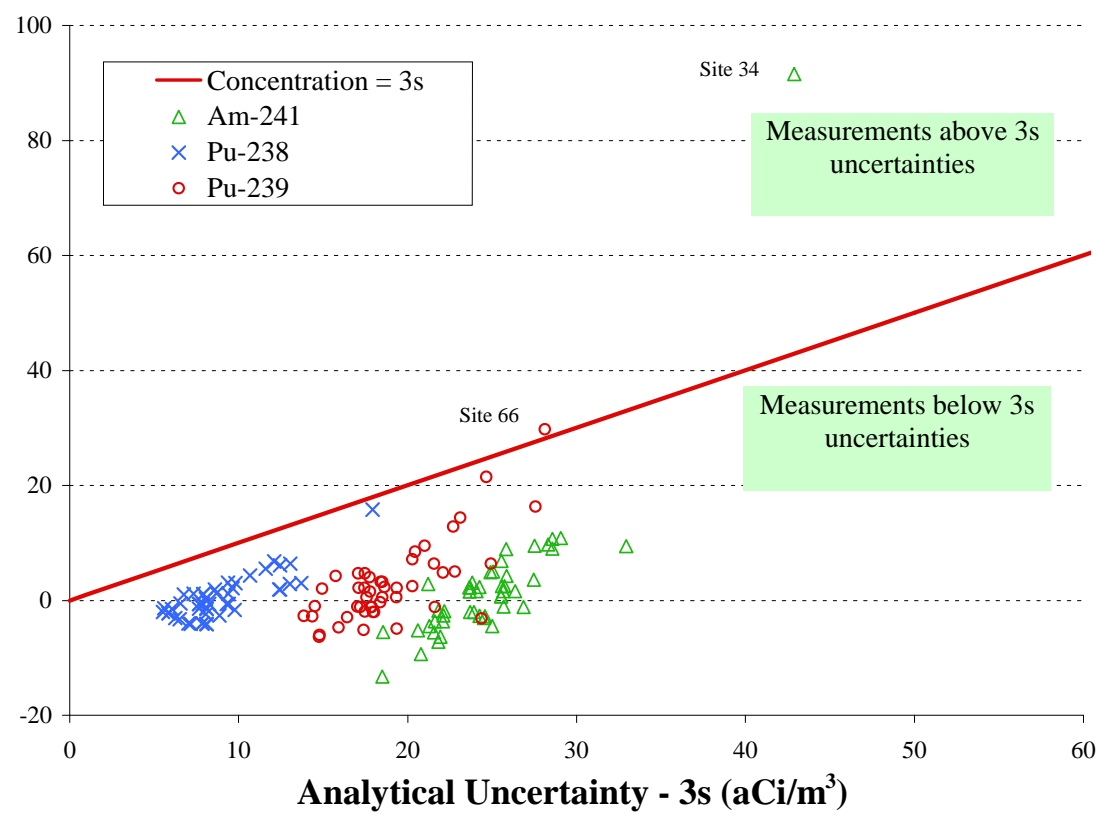

Figure 30. Two-week americium and plutonium concentrations at the beginning of the Cerro Grande fire (000508 samples). 


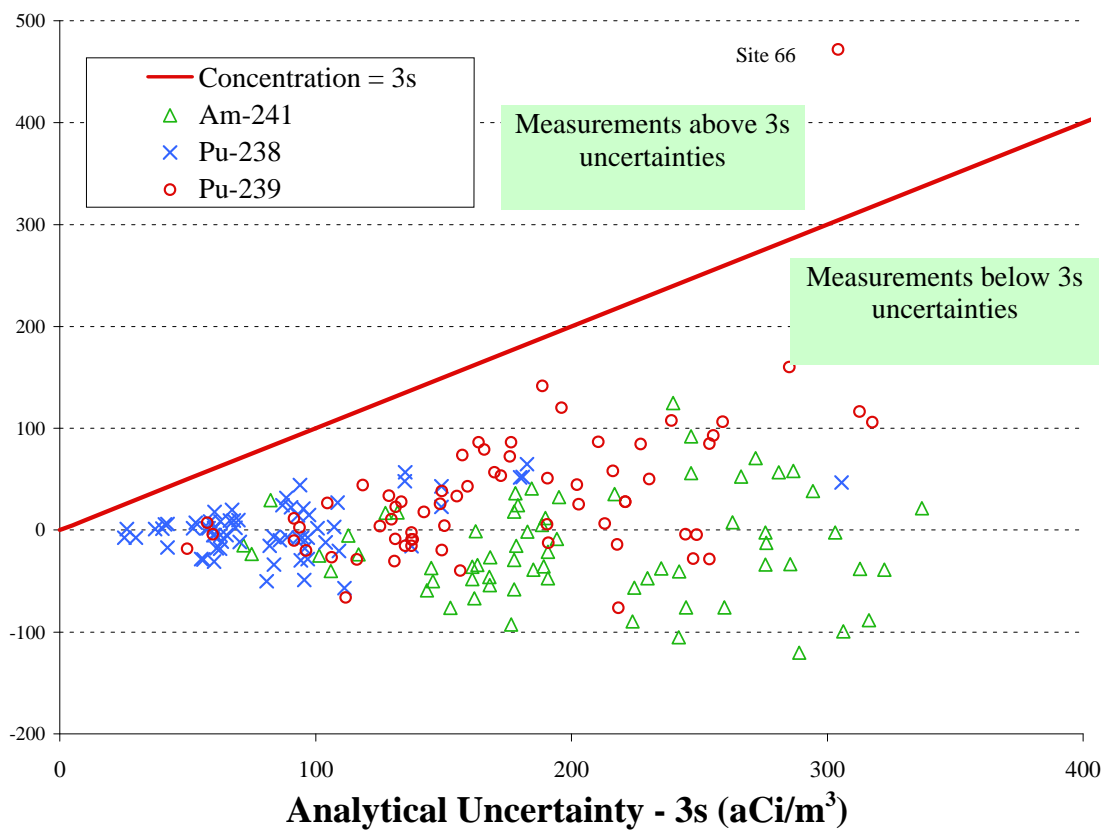

Figure 31. Short-term americium and plutonium concentrations during the Cerro Grande fire ( May 9-14, 2000).

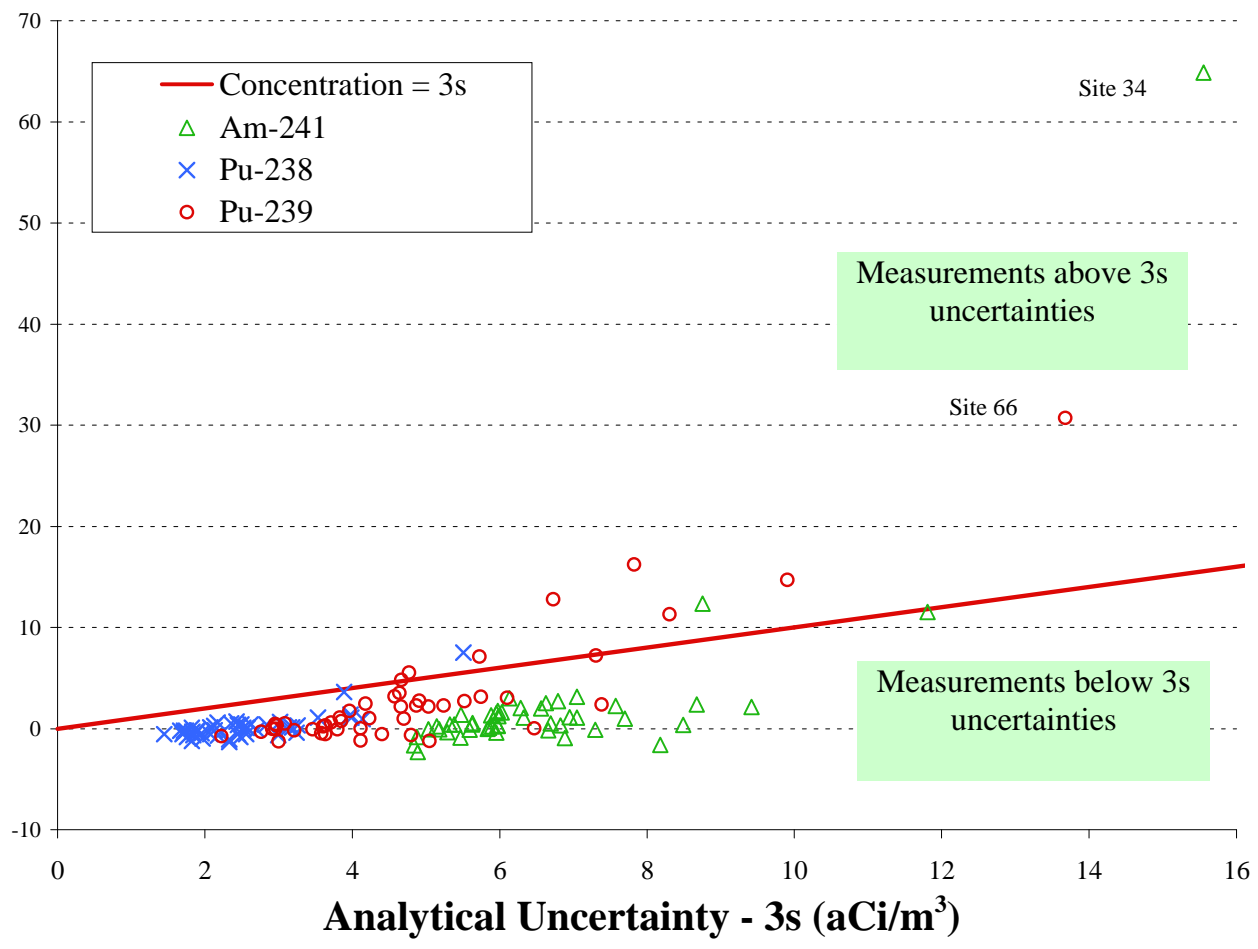

Figure 32. Second quarter 2000 americium and plutonium concentrations. 


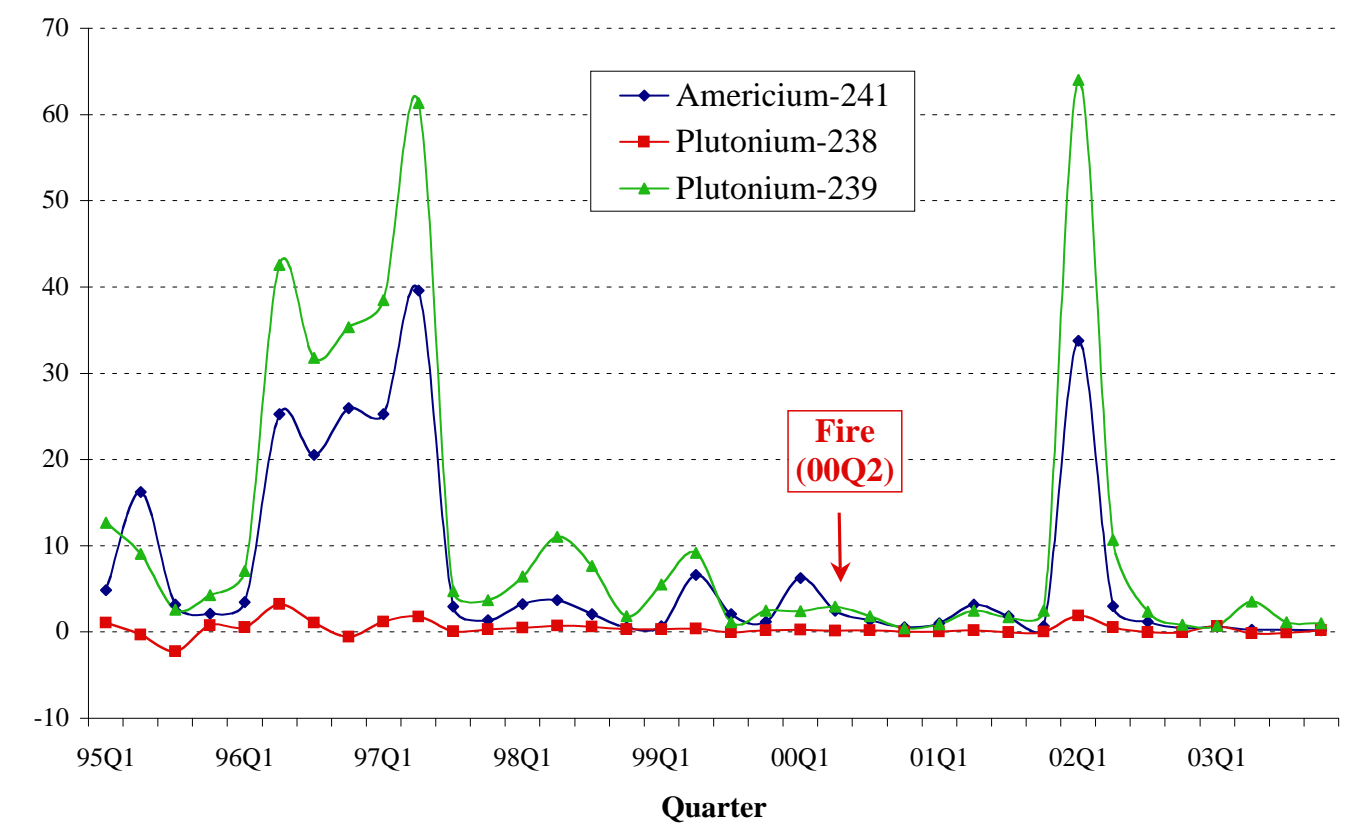

Figure 33. AIRNET quarterly plutonium and americium concentrations.

\section{Other Radionuclides as Measured by Gamma Spectroscopy}

The gamma spectroscopy data did not indicate any radionuclides other than from natural sources (Table A-15). The beryllium-7 and the lead-210 measurements are the only radionuclides normally above their minimum detectable activities, but two other radon decay chains, radon-220 and radon-219, also contribute to the radioactivity collected on the filters. Neither chain produces radionuclides that are present in measurable quantities when the AIRNET samples are analyzed, which is typically one to three weeks after the filters are collected in the field. The radon-219 decay products are gone within hours after collection because the longest-lived progeny has a half-life of 36 minutes. The radon-220 decay chain (Figure 34) lasts somewhat longer than the radon-219 chain because one of its decay products, lead-212, has a half-life of 10.6 hours. Some of the AIRNET samples collected during the fire were hand-delivered to the analytical laboratory and counted within a couple of days after collection. Several additional radionuclides from the radon-220 decay chain were detected (lead-212, bismuth-212, and thallium-208) because of this quick turnaround.

Beryllium-7 is cosmogenically produced by the spallation of common atmospheric gases. Like the radon decay products, it is a solid material produced from gas. The fine particles quickly coalesce into larger particles and also deposit on other surfaces such as vegetation. Beryllium-7 has a relatively short half-life, 53 days, but it is long enough to accumulate to some extent in the forests and be released during fires similar to the releases of the radon-222 decay products. Beryllium-7 short-term measurements increased during the fire (Figure 35) while the lead-210 levels were below their detection limits (Figure 36). Concentrations of beryllium-7 and lead-210 returned to pre-fire levels for the samples collected the week of May 22, 2000. 


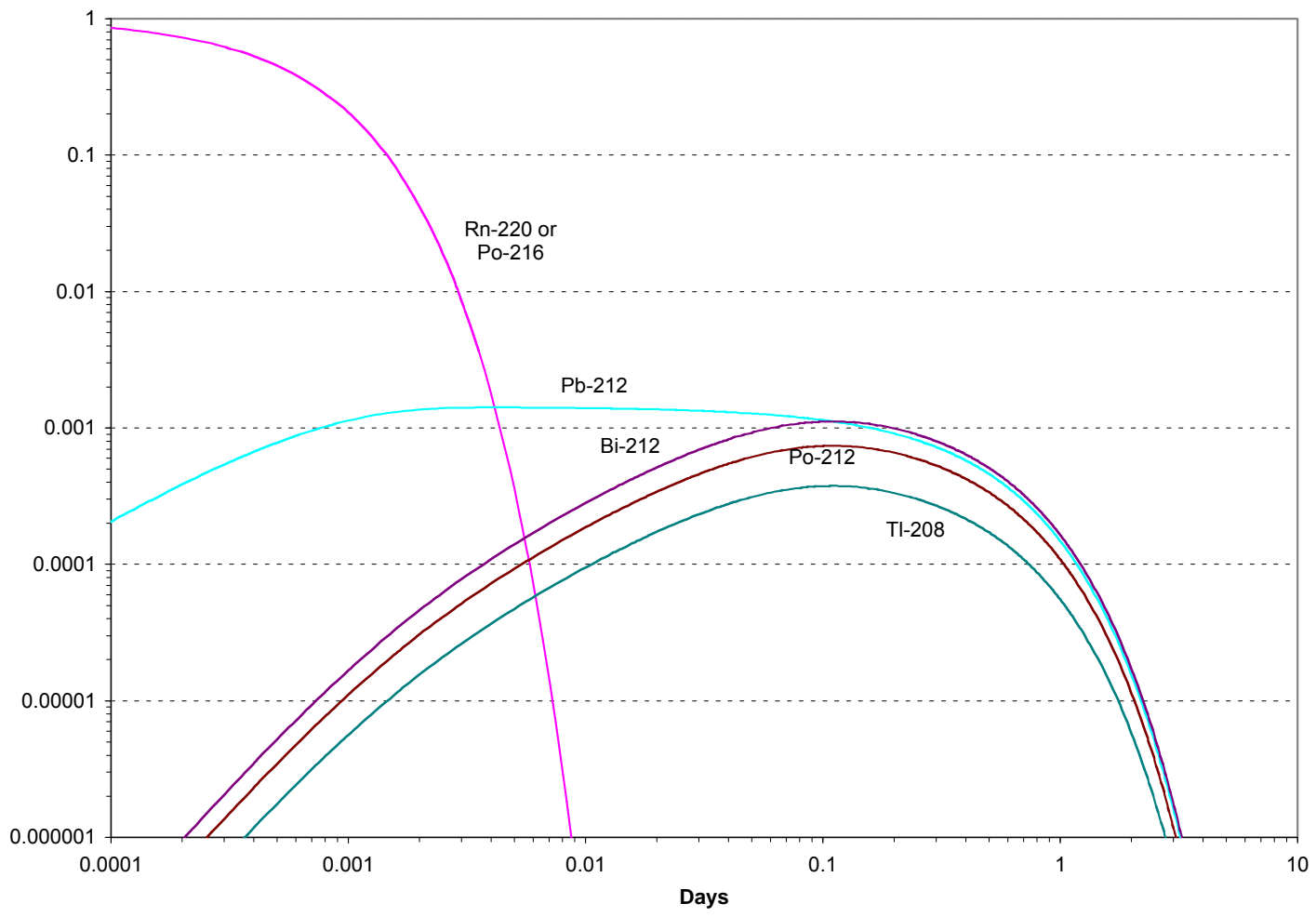

Figure 34. Radon-222 decay chain.

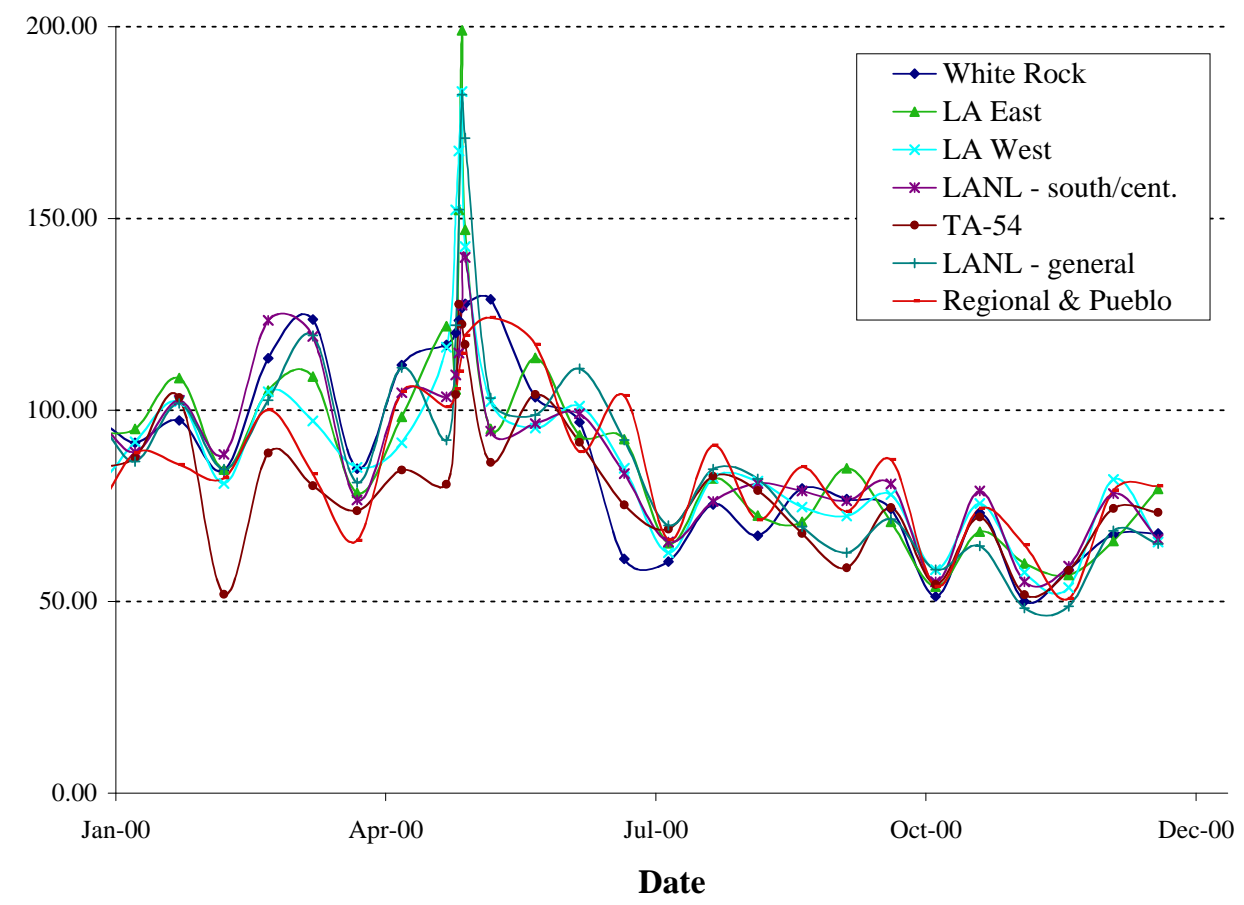

Figure 35. Beryllium-7 gamma spectroscopy measurements grouped by general location. 


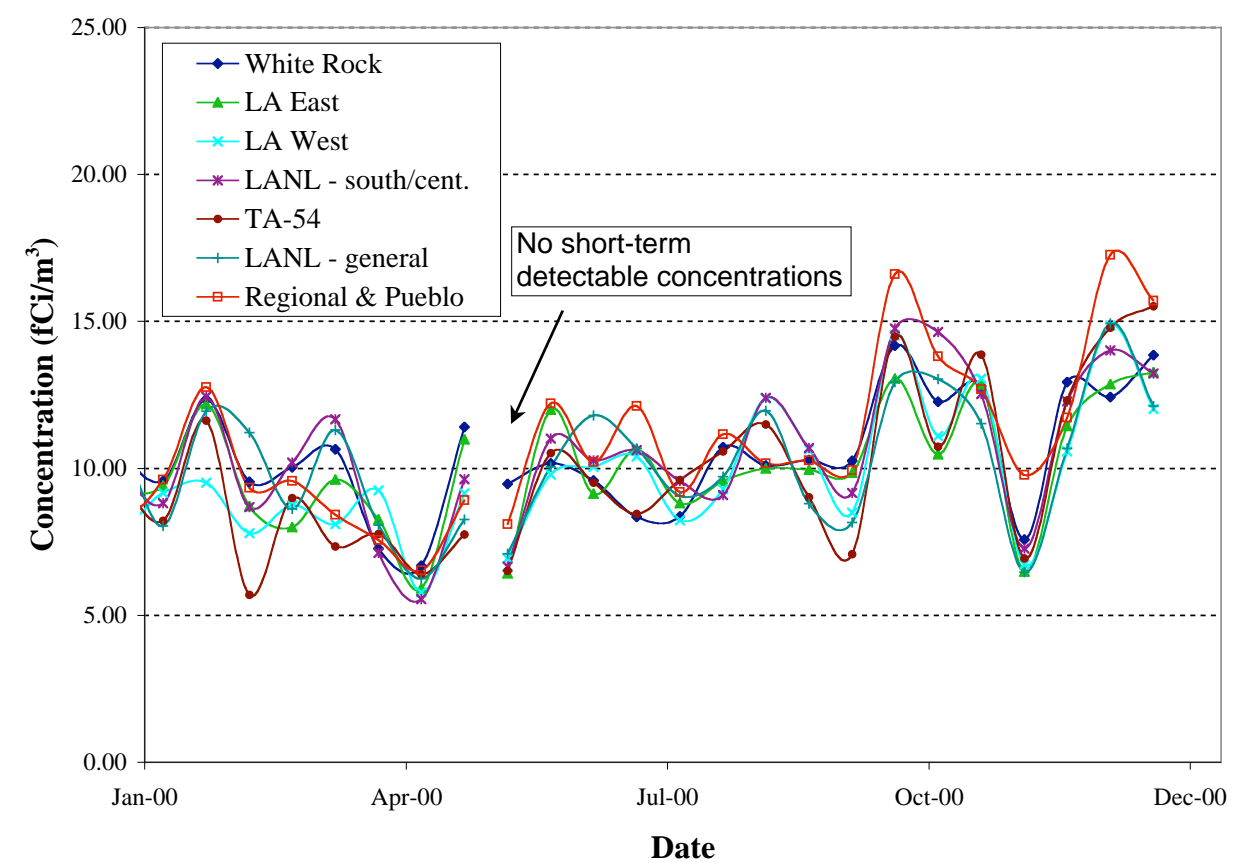

Figure 36. Lead-210 gamma spectroscopy measurements grouped by general location.

\section{Acknowledgments}

Many people at LANL, the US Department of Energy, and the contract laboratories contributed to our successful efforts to collect and analyze air samples during and after the Cerro Grande fire. I would especially like to recognize the following people for their dedicated efforts that gave me the opportunity to write this paper:

Jean Dewart for her leadership, support, and field sampling;

Ernie Gladney for his chemistry expertise and efforts to get the data correct;

David Kraig for his health physics expertise and understanding of the data;

Alice Baumann and Jake Martinez for their field sampling during the fire; and

Mike McNaughton, Tom Buhl, and Andrew Green for their health physics expertise.

\section{References}

Duncan 1986: A. J. Duncan, Quality Control and Industrial Statistics, $5^{\text {th }}$ ed. (Irwin, Homewood, IL, 1986) $1123 \mathrm{pp}$.

Eberhart et al. 1999: C. F. Eberhart, J. M. Dewart, D. H. Kraig, and E. S. Gladney, "Detecting Emissions of Uranium Using Ambient Isotopic Measurements," in extended abstracts from PM2000: Particulate Matter and Health—The Scientific Basis for Regulatory Decision-Making, Los Alamos National Laboratory document LA-UR-99-5724 (January 2000). 
Eisenbud and Gesell 1997: M. Eisenbud and T. Gesell, Environmental Radioactivity from Natural, Industrial, and Military Sources, 4th ed. (Academic Press, San Diego, CA, 1997).

ESP 1999: Environmental Surveillance Program, "Environmental Surveillance at Los Alamos during 1998,” Los Alamos National Laboratory report LA-13633-ENV (September 1999).

ESP 2000: Environmental Surveillance Program, "Environmental Surveillance at Los Alamos during 1999,” Los Alamos National Laboratory report LA-13775-ENV (December 2000).

ESP 2001: Environmental Surveillance Program, "Environmental Surveillance at Los Alamos during 2000,” Los Alamos National Laboratory report LA-13861-ENV (October 2001).

Gilbert 1987: R. O. Gilbert, Statistical Methods for Environmental Pollution Monitoring (Van Nostrand Reinhold, New York, 1987), 320 pp.

Lambert et al. 1991: G. Lambert, M. F. Le Cloarec, B. Ardouin, and B. Bonsang, "Long-lived Radon Daughters Signature of Savanna Fires,” pages 181-4 of the conference proceedings “Global Biomass Burning,” ed. Joel S. Levine, MIT Press (1991).

LANL 2000: Los Alamos National Laboratory, "A Special Edition of the SWEIS Yearbook: Wildfire 2000," Los Alamos National Laboratory document LA-UR-00-3471 (August 2000).

Le Cloarec et al. 1995: M. F. Le Cloarec, B. Ardouin, H. Cachier, C. Liousse, S. Neveu, and E.Y. Nho, “210Po in Savanna Burning Plumes,” J. of Atmospheric Chem., vol. 22, pp 111-122 (1995).

Reinhardt et al. 2004: T. Reinhardt, C. Wrobels, and C. Eberhart, "Radionuclide Emission Factors from Prescribed Burns in Northern New Mexico,” Los Alamos National Laboratory report LA-14113.

Rogers et al. 2000: J. Rogers, P. Wasiolek, J. Whicker, C. F. Eberhart, K. Saxton, and D. Chandler, "Performance Evaluation of LANL Environmental Radiological Air Monitoring Inlets at High Wind Velocities Associated with Resuspension," Los Alamos National Laboratory report LA-UR-00-3091 (2000) 38 pp.

Walker et al. 1989: F. W. Walker, J. R. Parrington, and F. Feiner, Nuclides and Isotopes, 14th ed. (General Electric Company 1989).

Whicker et al. 2001: J. J. Whicker, D. D. Breshears, P. T. Wasiolek, T. B. Kirchner, R. A. Tavani, D. A. Schoep, and J. C. Rodgers, "Temporal and Spatial Variation of Episodic Wind Erosion in Unburned and Burned Semiarid Shrubland,” submitted to the Journal of Environmental Quality (March 2001). 
Appendix

A-1 
A-2 


\section{Table A-1. AIRNET Sampler Locations}

\begin{tabular}{|c|c|c|c|c|}
\hline Site Number & Site Name & Latitude & Longitude & $\begin{array}{l}\text { Altitude } \\
\text { (m) }\end{array}$ \\
\hline 01 & Española & 35.0042 & 106.0825 & 1726 \\
\hline 03 & Santa Fe & 35.6540 & 106.9808 & 2069 \\
\hline 04 & Barranca School & 35.9027 & 106.2822 & 2243 \\
\hline 05 & Urban Park & 35.8920 & 106.3257 & 2253 \\
\hline 06 & 48th Street (Twin Tanks Complex) & 35.8830 & 106.3288 & 2286 \\
\hline 07 & Gulf/Exxon/Shell Station & 35.8807 & 106.3057 & 2238 \\
\hline 08 & McDonalds & 35.8782 & 106.2973 & 2234 \\
\hline 09 & Los Alamos Airport & 35.8822 & 106.2758 & 2192 \\
\hline 10 & Eastgate & 35.8753 & 106.2555 & 2146 \\
\hline 11 & Well PM-1 (E. Jemez Road) & 35.8593 & 106.2255 & 1995 \\
\hline 12 & Royal Crest Trailer Court & 35.8723 & 106.2997 & 2228 \\
\hline 13 & Rocket Park (formerly Piñon School) & 35.8243 & 106.2120 & 1965 \\
\hline 14 & Pajarito Acres & 35.8104 & 106.2134 & 1959 \\
\hline 15 & White Rock Fire Station & 35.8280 & 106.2058 & 1954 \\
\hline 16 & White Rock Nazarene Church & 35.8225 & 106.2218 & 1999 \\
\hline 17 & Bandelier Fire Lookout (near park entrance) & 35.7805 & 106.2663 & 1991 \\
\hline 20 & TA-21 Area B & 35.8780 & 106.2812 & 2208 \\
\hline 23 & TA-5 (formerly TA-52, Beta Site) & 35.8590 & 106.2799 & 2169 \\
\hline 25 & TA-16-450 & 35.8396 & 106.3536 & 2317 \\
\hline 26 & TA-49 & 35.8262 & 106.3178 & 2214 \\
\hline 27 & TA-54 Area G (by QA) & 35.8316 & 106.2365 & 2037 \\
\hline 30 & Pajarito Booster 2 (P-2) & 35.8458 & 106.2676 & 2113 \\
\hline 31 & TA-3 & 35.8735 & 106.3227 & 2248 \\
\hline 32 & Los Alamos County Landfill & 35.8778 & 106.3170 & 2262 \\
\hline 34 & TA-54 Area G-1 (behind trailer) & 35.8320 & 106.2345 & 2029 \\
\hline 35 & TA-54 Area G-2 (back fence) & 35.8293 & 106.2387 & 2037 \\
\hline 36 & TA-54 Area G-3 (by office) & 35.8329 & 106.2450 & 2056 \\
\hline 38 & TA-54 Area G-QA (next to \# 27) & 35.8321 & 106.2369 & 2037 \\
\hline 39 & TA-49-QA (adjacent to \# 26) & 35.8262 & 106.3178 & 2214 \\
\hline 41 & San Ildefonso Pueblo Plaza & 35.8923 & 106.1210 & 1701 \\
\hline 45 & TA-54 - Area G/ Southeast Perimeter & 35.8317 & 106.2368 & 2038 \\
\hline 47 & TA-54 - Area G/ North Perimeter & 35.8300 & 106.2343 & 2040 \\
\hline 49 & Pajarito Road (TA-36) & 35.8323 & 106.2523 & 2031 \\
\hline 50 & TA-54 - Area G - expansion & 35.8318 & 106.2355 & 2062 \\
\hline 51 & TA-54 - Area G - expansion pit & 35.8267 & 106.2408 & 2056 \\
\hline 54 & TA-33 East & 35.7755 & 106.2455 & 1967 \\
\hline 55 & Santa Fe West (Buckman Booster \#4) & 35.7027 & 106.0165 & 2084 \\
\hline 56 & El Rancho & 35.8953 & 106.0763 & 1747 \\
\hline 59 & Jemez Pueblo - Visitor's Center & 35.6111 & 106.7425 & 1829 \\
\hline 60 & LA Canyon & 35.8778 & 106.3073 & 2135 \\
\hline 61 & LA Hospital & 35.8822 & 106.3167 & 2245 \\
\hline 62 & Crossroads Bible Church (formerly Trinity Bible Church) & 35.8808 & 106.2878 & 2216 \\
\hline 63 & Monte Rey South & 35.8113 & 106.2248 & 1984 \\
\hline 66 & Los Alamos Inn - South & 35.9620 & 106.3043 & 2240 \\
\hline 71 & TA-21.01 (NW Bldg 344) & 35.8787 & 106.2787 & 2187 \\
\hline 76 & TA-15-41 (formerly -61) & 35.8438 & 106.3015 & 2220 \\
\hline 77 & TA-36 IJ site & 35.8370 & 106.2922 & 2187 \\
\hline 78 & TA-15-N & 35.8458 & 106.2848 & 2199 \\
\hline 90 & Eastgate - Backup & 35.8753 & 106.2555 & 2146 \\
\hline
\end{tabular}


Table A-2. Validated AIRNET Samples Collected in 2000

\begin{tabular}{|c|c|c|c|c|c|c|c|}
\hline Site Number & Sample Period & Sample Number & $\underset{\mathbf{m}^{3}}{\text { Air Volume }}$ & Start Date & $\begin{array}{c}\text { Start Time } \\
(\text { MST) }\end{array}$ & End Date & $\begin{array}{l}\text { End Time } \\
\text { (MST) }\end{array}$ \\
\hline 01 & 000508 & 000508.01 & 2289 & $4 / 25 / 2000$ & $12: 05$ & $5 / 10 / 2000$ & $11: 30$ \\
\hline 01 & 000511 & 000511.01 & 193 & $5 / 10 / 2000$ & $11: 30$ & $5 / 11 / 2000$ & $19: 35$ \\
\hline 01 & 000522 & 000522.01 & 1641 & $5 / 13 / 2000$ & $10: 47$ & $5 / 24 / 2000$ & $8: 10$ \\
\hline 03 & 000508 & 000508.03 & 2124 & $4 / 26 / 2000$ & $13: 10$ & $5 / 10 / 2000$ & $8: 28$ \\
\hline 03 & 000511 & 000511.03 & 228 & $5 / 10 / 2000$ & $8: 28$ & $5 / 11 / 2000$ & $18: 07$ \\
\hline 03 & 000522 & 000522.03 & 1401 & $5 / 13 / 2000$ & $9: 50$ & $5 / 23 / 2000$ & $9: 05$ \\
\hline 04 & 000508 & 000508.04 & 2401 & $4 / 24 / 2000$ & 10:02 & $5 / 9 / 2000$ & $9: 39$ \\
\hline 04 & 000511 & 000511.04 & 306 & $5 / 9 / 2000$ & $9: 39$ & $5 / 11 / 2000$ & $12: 30$ \\
\hline 04 & 000513 & 000513.04 & 220 & $5 / 11 / 2000$ & $12: 30$ & $5 / 13 / 2000$ & $16: 47$ \\
\hline 04 & 000522 & 000522.04 & 1681 & $5 / 13 / 2000$ & $16: 47$ & $5 / 24 / 2000$ & $10: 17$ \\
\hline 05 & 000508 & 000508.05 & 2488 & $4 / 24 / 2000$ & $10: 27$ & $5 / 9 / 2000$ & $9: 53$ \\
\hline 05 & 000511 & 000511.05 & 98 & $5 / 9 / 2000$ & $9: 53$ & $5 / 11 / 2000$ & $12: 00$ \\
\hline 06 & 000508 & 000508.06 & 2469 & $4 / 24 / 2000$ & $10: 38$ & $5 / 9 / 2000$ & 10:04 \\
\hline 06 & 000511 & 000511.06 & 170 & $5 / 9 / 2000$ & $10: 04$ & $5 / 11 / 2000$ & $11: 30$ \\
\hline 06 & 000513 & 000513.06 & 217 & $5 / 11 / 2000$ & $11: 30$ & $5 / 13 / 2000$ & $16: 30$ \\
\hline 06 & 000522 & 000522.06 & 1478 & $5 / 13 / 2000$ & $16: 30$ & $5 / 23 / 2000$ & $9: 18$ \\
\hline 07 & 000508 & 000508.07 & 2268 & $4 / 24 / 2000$ & $10: 51$ & $5 / 9 / 2000$ & $10: 19$ \\
\hline 07 & 000511 & 000511.07 & 165 & $5 / 9 / 2000$ & $10: 19$ & $5 / 11 / 2000$ & $13: 39$ \\
\hline 07 & 000513 & 000513.07 & 200 & $5 / 11 / 2000$ & $13: 39$ & $5 / 13 / 2000$ & $14: 30$ \\
\hline 07 & 000522 & 000522.07 & 1372 & $5 / 13 / 2000$ & $14: 30$ & $5 / 23 / 2000$ & $9: 36$ \\
\hline 08 & 000508 & 000508.08 & 2285 & $4 / 24 / 2000$ & $11: 00$ & $5 / 9 / 2000$ & $10: 27$ \\
\hline 08 & 000511 & 000511.08 & 169 & $5 / 9 / 2000$ & $10: 27$ & $5 / 11 / 2000$ & $13: 51$ \\
\hline 08 & 000513 & 000513.08 & 163 & $5 / 11 / 2000$ & $13: 51$ & $5 / 13 / 2000$ & $15: 00$ \\
\hline 08 & 000522 & 000522.08 & 1531 & $5 / 13 / 2000$ & $15: 00$ & $5 / 23 / 2000$ & $9: 56$ \\
\hline 09 & 000508 & 000508.09 & 2335 & $4 / 24 / 2000$ & $11: 27$ & $5 / 9 / 2000$ & $10: 53$ \\
\hline 09 & 000511 & 000511.09 & 166 & $5 / 9 / 2000$ & $10: 53$ & $5 / 11 / 2000$ & $14: 18$ \\
\hline 09 & 000513 & 000513.09 & 204 & $5 / 11 / 2000$ & $14: 18$ & $5 / 13 / 2000$ & $15: 30$ \\
\hline 09 & 000522 & 000522.09 & 1457 & $5 / 13 / 2000$ & $15: 30$ & $5 / 23 / 2000$ & $10: 38$ \\
\hline 10 & 000511 & 000511.10 & 347 & $5 / 9 / 2000$ & $11: 01$ & $5 / 11 / 2000$ & $14: 45$ \\
\hline 10 & 000513 & 000513.10 & 221 & $5 / 11 / 2000$ & $14: 45$ & $5 / 13 / 2000$ & $15: 40$ \\
\hline 10 & 000522 & 000522.10 & 1457 & $5 / 13 / 2000$ & $15: 40$ & $5 / 23 / 2000$ & $10: 47$ \\
\hline 11 & 000508 & 000508.11 & 2257 & $4 / 24 / 2000$ & $13: 37$ & $5 / 9 / 2000$ & $9: 04$ \\
\hline 11 & 000513 & 000513.11 & 459 & $5 / 9 / 2000$ & 9:04 & $5 / 13 / 2000$ & $19: 13$ \\
\hline 11 & 000522 & 000522.11 & 1354 & $5 / 13 / 2000$ & 19:13 & $5 / 23 / 2000$ & $10: 35$ \\
\hline 12 & 000508 & 000508.12 & 2272 & $4 / 24 / 2000$ & $13: 25$ & $5 / 9 / 2000$ & $9: 14$ \\
\hline 12 & 000514 & 000514.12 & 437 & $5 / 9 / 2000$ & $9: 14$ & $5 / 14 / 2000$ & $7: 52$ \\
\hline 12 & 000522 & 000522.12 & 1315 & $5 / 14 / 2000$ & $7: 52$ & $5 / 23 / 2000$ & $10: 46$ \\
\hline 13 & 000508 & 000508.13 & 2344 & $4 / 24 / 2000$ & $14: 00$ & $5 / 9 / 2000$ & $8: 52$ \\
\hline 13 & 000513 & 000513.13 & 729 & $5 / 9 / 2000$ & $8: 52$ & $5 / 13 / 2000$ & $18: 47$ \\
\hline 13 & 000522 & 000522.13 & 1610 & $5 / 13 / 2000$ & $18: 47$ & $5 / 23 / 2000$ & 14:01 \\
\hline 14 & 000508 & 000508.14 & 2395 & $4 / 24 / 2000$ & 14:07 & $5 / 9 / 2000$ & $8: 45$ \\
\hline 14 & 000513 & 000513.14 & 702 & $5 / 9 / 2000$ & $8: 45$ & $5 / 13 / 2000$ & $18: 47$ \\
\hline 14 & 000522 & 000522.14 & 1570 & $5 / 13 / 2000$ & $18: 47$ & $5 / 23 / 2000$ & $13: 26$ \\
\hline 15 & 000508 & 000508.15 & 2407 & $4 / 24 / 2000$ & $13: 45$ & $5 / 9 / 2000$ & $8: 57$ \\
\hline 15 & 000513 & 000513.15 & 459 & $5 / 9 / 2000$ & $8: 57$ & $5 / 13 / 2000$ & 19:01 \\
\hline 15 & 000522 & 000522.15 & 1417 & $5 / 13 / 2000$ & 19:01 & $5 / 23 / 2000$ & $14: 22$ \\
\hline 16 & 000508 & 000508.16 & 2395 & $4 / 24 / 2000$ & $14: 16$ & $5 / 9 / 2000$ & $8: 35$ \\
\hline 16 & 000513 & 000513.16 & 329 & $5 / 9 / 2000$ & $8: 35$ & $5 / 13 / 2000$ & $18: 33$ \\
\hline 16 & 000522 & 000522.16 & 1570 & $5 / 13 / 2000$ & $18: 33$ & $5 / 23 / 2000$ & $13: 13$ \\
\hline 17 & 000508 & 000508.17 & 2354 & $4 / 25 / 2000$ & $11: 20$ & $5 / 10 / 2000$ & 10:09 \\
\hline 17 & 000512 & 000512.17 & 347 & $5 / 10 / 2000$ & $10: 09$ & $5 / 12 / 2000$ & $13: 34$ \\
\hline 17 & 000514 & 000514.17 & 301 & $5 / 12 / 2000$ & $13: 34$ & $5 / 14 / 2000$ & $11: 27$ \\
\hline 17 & 000522 & 000522.17 & 1463 & $5 / 14 / 2000$ & $11: 27$ & $5 / 23 / 2000$ & $13: 29$ \\
\hline 20 & 000508 & 000508.20 & 2284 & $4 / 24 / 2000$ & $11: 14$ & $5 / 9 / 2000$ & $10: 35$ \\
\hline 20 & 000511 & 000511.20 & 269 & $5 / 9 / 2000$ & $10: 35$ & $5 / 11 / 2000$ & $14: 00$ \\
\hline 20 & 000513 & 000513.20 & 200 & $5 / 11 / 2000$ & $14: 00$ & $5 / 13 / 2000$ & $15: 10$ \\
\hline 20 & 000522 & 000522.20 & 1358 & $5 / 13 / 2000$ & $15: 10$ & $5 / 23 / 2000$ & $10: 21$ \\
\hline 23 & 000508 & 000508.23 & 2288 & $4 / 24 / 2000$ & $15: 03$ & $5 / 9 / 2000$ & $8: 13$ \\
\hline 23 & 000513 & 000513.23 & 221 & $5 / 9 / 2000$ & $8: 13$ & $5 / 13 / 2000$ & $18: 12$ \\
\hline 23 & 000522 & 000522.23 & 1471 & $5 / 13 / 2000$ & $18: 12$ & $5 / 23 / 2000$ & $12: 49$ \\
\hline 25 & 000508 & 000508.25 & 2096 & $4 / 25 / 2000$ & $13: 40$ & $5 / 10 / 2000$ & $8: 53$ \\
\hline 25 & 000512 & 000512.25 & 172 & $5 / 10 / 2000$ & $8: 53$ & $5 / 12 / 2000$ & $13: 03$ \\
\hline 25 & 000514 & 000514.25 & 289 & $5 / 12 / 2000$ & $13: 03$ & $5 / 14 / 2000$ & $10: 36$ \\
\hline 25 & 000522 & 000522.25 & 1475 & $5 / 14 / 2000$ & $10: 36$ & $5 / 23 / 2000$ & $12: 35$ \\
\hline 26 & 000508 & 000508.26 & 2305 & $4 / 25 / 2000$ & $11: 36$ & $5 / 10 / 2000$ & $9: 34$ \\
\hline 26 & 000512 & 000512.26 & 306 & $5 / 10 / 2000$ & $9: 34$ & $5 / 12 / 2000$ & $13: 23$ \\
\hline 26 & 000514 & 000514.26 & 305 & $5 / 12 / 2000$ & $13: 23$ & $5 / 14 / 2000$ & $11: 16$ \\
\hline 26 & 000522 & 000522.26 & 1493 & $5 / 14 / 2000$ & $11: 16$ & $5 / 23 / 2000$ & $13: 10$ \\
\hline 27 & 000508 & 000508.27 & 2448 & $4 / 25 / 2000$ & 9:08 & $5 / 10 / 2000$ & $12: 01$ \\
\hline 27 & 000512 & 000512.27 & 269 & $5 / 10 / 2000$ & $12: 01$ & $5 / 12 / 2000$ & $11: 25$ \\
\hline 27 & 000514 & 000514.27 & 294 & $5 / 12 / 2000$ & $11: 25$ & $5 / 14 / 2000$ & 9:19 \\
\hline
\end{tabular}


Table A-2 (cont.)

\begin{tabular}{|c|c|c|c|c|c|c|c|}
\hline Site Number & Sample Period & Sample Number & $\underset{\mathbf{m}^{3}}{\text { Air Volume }}$ & Start Date & $\begin{array}{c}\text { Start Time } \\
\text { (MST) }\end{array}$ & End Date & $\begin{array}{c}\text { End Time } \\
\text { (MST) }\end{array}$ \\
\hline 27 & 000522 & 000522.27 & 1470 & $5 / 14 / 2000$ & $9: 19$ & $5 / 24 / 2000$ & $7: 10$ \\
\hline 30 & 000508 & 000508.30 & 2387 & $4 / 24 / 2000$ & $14: 27$ & $5 / 9 / 2000$ & $8: 25$ \\
\hline 30 & 000514 & 000514.30 & 449 & $5 / 9 / 2000$ & $8: 25$ & $5 / 14 / 2000$ & $8: 34$ \\
\hline 30 & 000522 & 000522.30 & 1358 & $5 / 14 / 2000$ & $8: 34$ & $5 / 23 / 2000$ & $14: 43$ \\
\hline 31 & 000508 & 000508.31 & 2162 & $4 / 25 / 2000$ & $12: 35$ & $5 / 10 / 2000$ & $8: 29$ \\
\hline 31 & 000512 & 000512.31 & 316 & $5 / 10 / 2000$ & $8: 29$ & $5 / 12 / 2000$ & $11: 49$ \\
\hline 31 & 000514 & 000514.31 & 309 & $5 / 12 / 2000$ & $11: 49$ & $5 / 14 / 2000$ & $10: 11$ \\
\hline 31 & 000522 & 000522.31 & 1383 & $5 / 14 / 2000$ & $10: 11$ & $5 / 23 / 2000$ & $12: 08$ \\
\hline 32 & 000508 & 000508.32 & 2274 & $4 / 24 / 2000$ & $13: 17$ & $5 / 9 / 2000$ & $9: 23$ \\
\hline 32 & 000514 & 000514.32 & 437 & $5 / 9 / 2000$ & $9: 23$ & $5 / 14 / 2000$ & $8: 02$ \\
\hline 32 & 000522 & 000522.32 & 1315 & $5 / 14 / 2000$ & $8: 02$ & $5 / 23 / 2000$ & 11:04 \\
\hline 34 & 000508 & 000508.34 & 2573 & $4 / 25 / 2000$ & $8: 47$ & $5 / 12 / 2000$ & $8: 31$ \\
\hline 34 & 000514 & 000514.34 & 321 & $5 / 12 / 2000$ & $8: 31$ & $5 / 14 / 2000$ & $9: 46$ \\
\hline 34 & 000522 & 000522.34 & 1456 & $5 / 14 / 2000$ & $9: 46$ & $5 / 24 / 2000$ & $8: 17$ \\
\hline 35 & 000508 & 000508.35 & 2424 & $4 / 25 / 2000$ & $9: 14$ & $5 / 10 / 2000$ & $12: 10$ \\
\hline 35 & 000512 & 000512.35 & 306 & $5 / 10 / 2000$ & $12: 10$ & $5 / 12 / 2000$ & $11: 37$ \\
\hline 35 & 000514 & 000514.35 & 283 & $5 / 12 / 2000$ & $11: 37$ & $5 / 14 / 2000$ & $9: 22$ \\
\hline 35 & 000522 & 000522.35 & 1490 & $5 / 14 / 2000$ & $9: 22$ & $5 / 24 / 2000$ & $7: 05$ \\
\hline 36 & 000508 & 000508.36 & 2438 & $4 / 25 / 2000$ & $9: 27$ & $5 / 10 / 2000$ & $11: 50$ \\
\hline 36 & 000512 & 000512.36 & 285 & $5 / 10 / 2000$ & $11: 50$ & $5 / 12 / 2000$ & $11: 10$ \\
\hline 36 & 000514 & 000514.36 & 264 & $5 / 12 / 2000$ & $11: 10$ & $5 / 14 / 2000$ & $9: 05$ \\
\hline 36 & 000522 & 000522.36 & 1409 & $5 / 14 / 2000$ & $9: 05$ & $5 / 24 / 2000$ & $7: 26$ \\
\hline 38 & 000512 & 000512.38 & 277 & $5 / 10 / 2000$ & $12: 03$ & $5 / 12 / 2000$ & $11: 30$ \\
\hline 38 & 000514 & 000514.38 & 294 & $5 / 12 / 2000$ & $11: 30$ & $5 / 14 / 2000$ & $9: 18$ \\
\hline 38 & 000522 & 000522.38 & 1450 & $5 / 14 / 2000$ & $9: 18$ & $5 / 24 / 2000$ & $7: 12$ \\
\hline 39 & 000508 & 000508.39 & 2325 & $4 / 25 / 2000$ & $11: 34$ & $5 / 10 / 2000$ & $9: 32$ \\
\hline 39 & 000512 & 000512.39 & 306 & $5 / 10 / 2000$ & $9: 32$ & $5 / 12 / 2000$ & $13: 22$ \\
\hline 39 & 000514 & 000514.39 & 313 & $5 / 12 / 2000$ & $13: 22$ & $5 / 14 / 2000$ & $11: 16$ \\
\hline 39 & 000522 & 000522.39 & 1364 & $5 / 14 / 2000$ & $11: 16$ & $5 / 23 / 2000$ & $13: 08$ \\
\hline 41 & 000508 & 000508.41 & 2173 & $4 / 26 / 2000$ & $14: 58$ & $5 / 10 / 2000$ & 11:09 \\
\hline 41 & 000511 & 000511.41 & 190 & $5 / 10 / 2000$ & $11: 09$ & $5 / 11 / 2000$ & $16: 40$ \\
\hline 41 & 000522 & 000522.41 & 1476 & $5 / 13 / 2000$ & $8: 16$ & $5 / 23 / 2000$ & $6: 40$ \\
\hline 45 & 000508 & 000508.45 & 2652 & $4 / 25 / 2000$ & $8: 51$ & $5 / 12 / 2000$ & $8: 35$ \\
\hline 45 & 000514 & 000514.45 & 333 & $5 / 12 / 2000$ & $8: 35$ & $5 / 14 / 2000$ & $9: 50$ \\
\hline 45 & 000522 & 000522.45 & 1516 & $5 / 14 / 2000$ & $9: 50$ & $5 / 24 / 2000$ & $8: 21$ \\
\hline 47 & 000508 & 000508.47 & 2632 & $4 / 25 / 2000$ & $8: 43$ & $5 / 12 / 2000$ & $8: 26$ \\
\hline 47 & 000514 & 000514.47 & 333 & $5 / 12 / 2000$ & $8: 26$ & $5 / 14 / 2000$ & $9: 43$ \\
\hline 47 & 000522 & 000522.47 & 1557 & $5 / 14 / 2000$ & $9: 43$ & $5 / 24 / 2000$ & $8: 11$ \\
\hline 49 & 000508 & 000508.49 & 2441 & $4 / 24 / 2000$ & $14: 22$ & $5 / 9 / 2000$ & $8: 30$ \\
\hline 49 & 000513 & 000513.49 & 495 & $5 / 9 / 2000$ & $8: 30$ & $5 / 13 / 2000$ & $18: 24$ \\
\hline 50 & 000508 & 000508.50 & 2398 & $4 / 25 / 2000$ & $9: 18$ & $5 / 10 / 2000$ & $11: 57$ \\
\hline 50 & 000512 & 000512.50 & 277 & $5 / 10 / 2000$ & $11: 57$ & $5 / 12 / 2000$ & $11: 18$ \\
\hline 51 & 000508 & 000508.51 & 2415 & $4 / 25 / 2000$ & $9: 22$ & $5 / 10 / 2000$ & $11: 52$ \\
\hline 51 & 000512 & 000512.51 & 306 & $5 / 10 / 2000$ & $11: 52$ & $5 / 12 / 2000$ & $11: 13$ \\
\hline 51 & 000514 & 000514.51 & 287 & $5 / 12 / 2000$ & $11: 13$ & $5 / 14 / 2000$ & $9: 10$ \\
\hline 51 & 000522 & 000522.51 & 1496 & $5 / 14 / 2000$ & $9: 10$ & $5 / 24 / 2000$ & $7: 32$ \\
\hline 54 & 000508 & 000508.54 & 2649 & $4 / 25 / 2000$ & 11:02 & $5 / 14 / 2000$ & $14: 23$ \\
\hline 54 & 000522 & 000522.54 & 1658 & $5 / 14 / 2000$ & $14: 23$ & $5 / 24 / 2000$ & $12: 39$ \\
\hline 55 & 000508 & 000508.55 & 2078 & $4 / 26 / 2000$ & $13: 58$ & $5 / 10 / 2000$ & $8: 58$ \\
\hline 55 & 000511 & 000511.55 & 207 & $5 / 10 / 2000$ & $8: 58$ & $5 / 11 / 2000$ & $17: 45$ \\
\hline 55 & 000522 & 000522.55 & 1577 & $5 / 13 / 2000$ & $8: 58$ & $5 / 23 / 2000$ & $7: 39$ \\
\hline 56 & 000508 & 000508.56 & 2275 & $4 / 26 / 2000$ & $14: 37$ & $5 / 10 / 2000$ & $10: 48$ \\
\hline 56 & 000511 & 000511.56 & 195 & $5 / 10 / 2000$ & $10: 48$ & $5 / 11 / 2000$ & $17: 03$ \\
\hline 56 & 000522 & 000522.56 & 1633 & $5 / 12 / 2000$ & $17: 10$ & $5 / 23 / 2000$ & $6: 54$ \\
\hline 59 & 000508 & 000508.59 & 2407 & $4 / 24 / 2000$ & $10: 18$ & $5 / 10 / 2000$ & $13: 25$ \\
\hline 59 & 000522 & 000522.59 & 1461 & $5 / 10 / 2000$ & $13: 25$ & $5 / 22 / 2000$ & $8: 49$ \\
\hline 60 & 000508 & 000508.60 & 2213 & $4 / 25 / 2000$ & $11: 52$ & $5 / 10 / 2000$ & $10: 32$ \\
\hline 60 & 000512 & 000512.60 & 296 & $5 / 10 / 2000$ & $10: 32$ & $5 / 12 / 2000$ & $12: 00$ \\
\hline 60 & 000514 & 000514.60 & 305 & $5 / 12 / 2000$ & $12: 00$ & $5 / 14 / 2000$ & $10: 17$ \\
\hline 60 & 000522 & 000522.60 & 1611 & $5 / 14 / 2000$ & $10: 17$ & $5 / 24 / 2000$ & $10: 37$ \\
\hline 61 & 000508 & 000508.61 & 2286 & $4 / 24 / 2000$ & $10: 45$ & $5 / 9 / 2000$ & $10: 13$ \\
\hline 61 & 000511 & 000511.61 & 294 & $5 / 9 / 2000$ & $10: 13$ & $5 / 11 / 2000$ & $13: 20$ \\
\hline 61 & 000513 & 000513.61 & 225 & $5 / 11 / 2000$ & $13: 20$ & $5 / 13 / 2000$ & $16: 20$ \\
\hline 61 & 000522 & 000522.61 & 1419 & $5 / 13 / 2000$ & $16: 20$ & $5 / 23 / 2000$ & $9: 28$ \\
\hline 62 & 000508 & 000508.62 & 2282 & $4 / 24 / 2000$ & $11: 22$ & $5 / 9 / 2000$ & $10: 47$ \\
\hline 62 & 000511 & 000511.62 & 166 & $5 / 9 / 2000$ & $10: 47$ & $5 / 11 / 2000$ & $14: 12$ \\
\hline 62 & 000513 & 000513.62 & 221 & $5 / 11 / 2000$ & $14: 12$ & $5 / 13 / 2000$ & $15: 25$ \\
\hline 62 & 000522 & 000522.62 & 1397 & $5 / 13 / 2000$ & $15: 25$ & $5 / 23 / 2000$ & $10: 28$ \\
\hline 63 & 000508 & 000508.63 & 2462 & $4 / 24 / 2000$ & $14: 13$ & $5 / 9 / 2000$ & $8: 40$ \\
\hline 63 & 000513 & 000513.63 & 702 & $5 / 9 / 2000$ & $8: 40$ & $5 / 13 / 2000$ & $18: 40$ \\
\hline 63 & 000522 & 000522.63 & 1650 & $5 / 13 / 2000$ & $18: 40$ & $5 / 23 / 2000$ & $13: 20$ \\
\hline
\end{tabular}


Table A-2 (cont.) Site Number Sample Period

$\begin{array}{ll}66 & 000508 \\ 66 & 000513 \\ 66 & 000522 \\ 71 & 000508 \\ 71 & 000511 \\ 71 & 000513 \\ 71 & 000522 \\ 76 & 000508 \\ 76 & 000512 \\ 76 & 000522 \\ 77 & 000508 \\ 77 & 000512 \\ 77 & 000514 \\ 77 & 000522 \\ 78 & 000508 \\ 78 & 000512 \\ 78 & 000522 \\ 90 & 000508 \\ 90 & 000522\end{array}$

Sample Number

000508.66
000513.66
000522.66
000508.71
000511.71
000513.71
000522.71
000508.76
000512.76
000522.76
000508.77
000512.77
000514.77
000522.77
000508.78
000512.78
000522.78
000508.90
000522.90

$\begin{array}{cc}\begin{array}{c}\text { Air Volume } \\ \mathbf{m}^{3}\end{array} & \text { Start Date } \\ 2324 & 4 / 24 / 2000 \\ 287 & 5 / 10 / 2000 \\ 1457 & 5 / 13 / 2000 \\ 2236 & 4 / 24 / 2000 \\ 334 & 5 / 9 / 2000 \\ 208 & 5 / 11 / 2000 \\ 1358 & 5 / 13 / 2000 \\ 2201 & 4 / 25 / 2000 \\ 190 & 5 / 10 / 2000 \\ 1309 & 5 / 12 / 2000 \\ 2313 & 4 / 25 / 2000 \\ 197 & 5 / 10 / 2000 \\ 320 & 5 / 12 / 2000 \\ 1577 & 5 / 14 / 2000 \\ 2315 & 4 / 25 / 2000 \\ 193 & 5 / 10 / 2000 \\ 1454 & 5 / 12 / 2000 \\ 2343 & 4 / 24 / 2000 \\ 1577 & 5 / 13 / 2000\end{array}$

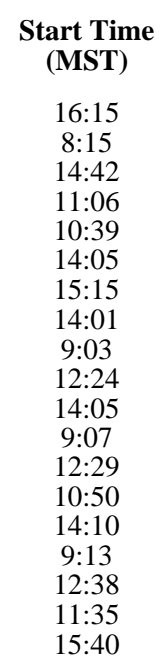

End Date $5 / 10 / 2000$ $5 / 13 / 2000$ $5 / 23 / 2000$ $5 / 9 / 2000$ $5 / 11 / 2000$ $5 / 13 / 2000$ $5 / 23 / 2000$ $5 / 10 / 2000$ $5 / 12 / 2000$ $5 / 24 / 2000$ $5 / 10 / 2000$ $5 / 12 / 2000$ $5 / 14 / 2000$ $5 / 24 / 2000$ $5 / 10 / 2000$ $5 / 12 / 2000$ $5 / 24 / 2000$ $5 / 9 / 2000$ $5 / 23 / 2000$
End Time (MST)

8:15

$14: 42$

$9: 47$

$10: 39$

$14: 05$

15:15

10:05

9:03

12:24

11:49

9:07

$12: 29$

10:50

11:55

9:13

12:38

12:02

11:02

10:48 


\begin{tabular}{|c|c|c|c|c|c|c|c|}
\hline \multirow{3}{*}{$\begin{array}{c}\text { Site } \\
\text { Number }\end{array}$} & \multicolumn{7}{|c|}{ Table A-3. Rejected AIRNET Samples Collected in May 2000} \\
\hline & Sample & Sample ID & Start & Start & End Date & End Time & Cause for Rejection \\
\hline & Period & & Date & $\begin{array}{l}\text { Time } \\
\text { (MST) }\end{array}$ & & (MST) & \\
\hline 01 & 000513 & 000513.01 & $5 / 11 / 00$ & $19: 35$ & $5 / 13 / 00$ & $10: 47$ & Filter material was not \\
\hline 03 & 000513 & 000513.03 & $5 / 11 / 00$ & 18:07 & $5 / 13 / 00$ & $9: 50$ & $\begin{array}{l}\text { Filter material was not } \\
\text { DynaWeb }\end{array}$ \\
\hline 05 & 000522 & 000522.05 & $5 / 11 / 00$ & $12: 00$ & $5 / 23 / 00$ & 9:00 & power failure \\
\hline 10 & 000508 & 000508.10 & $4 / 24 / 00$ & $11: 33$ & $5 / 9 / 00$ & 11:01 & filter did not cover inlet \\
\hline 38 & 000508 & 000508.38 & $4 / 25 / 00$ & $9: 10$ & $5 / 10 / 00$ & $12: 03$ & filter did not cover inlet \\
\hline 41 & 000513 & 000513.41 & $5 / 11 / 00$ & $16: 40$ & $5 / 13 / 00$ & $8: 16$ & $\begin{array}{l}\text { Filter material was not } \\
\text { DynaWeb }\end{array}$ \\
\hline 49 & 000522 & 000522.49 & $5 / 13 / 00$ & $18: 24$ & $5 / 23 / 00$ & 13:05 & circuit breaker tripped \\
\hline 50 & 000514 & 000514.50 & $5 / 12 / 00$ & $11: 18$ & $5 / 14 / 00$ & $9: 15$ & pump failure \\
\hline 50 & 000522 & 000522.50 & $5 / 14 / 00$ & $9: 15$ & $5 / 24 / 00$ & $7: 20$ & pump failure \\
\hline 55 & 000513 & 000513.55 & $5 / 11 / 00$ & $17: 45$ & $5 / 13 / 00$ & $8: 58$ & $\begin{array}{l}\text { Filter material was not } \\
\text { DynaWeb }\end{array}$ \\
\hline 56 & 000512 & 000512.56 & $5 / 11 / 00$ & $17: 03$ & $5 / 12 / 00$ & $17: 10$ & $\begin{array}{l}\text { Filter material was not } \\
\text { DynaWeb }\end{array}$ \\
\hline 90 & 000513 & 000513.90 & $5 / 9 / 00$ & 11:02 & $5 / 13 / 00$ & $15: 40$ & Start air flow not recorded \\
\hline
\end{tabular}

\section{Table A-4. Samples With More Than 5\% Downtime during the May 2000 Collection Period}

$\begin{array}{cccccc}\text { Site Number } & \text { Sample Period } & \text { Sample ID } & \text { Timer Reading } & \text { Potential Sampling Time } & \text { Percent Downtime } \\ 04 & 000511 & 000511.04 & 48 & 51 & 6 \\ 04 & 000513 & 000513.04 & 32 & 52 & 39 \\ 05 & 000511 & 000511.05 & 28 & 50 & 44 \\ 05 & 000522 & 000522.05 & 30 & 285 & 59 \\ 16 & 000513 & 000513.16 & 53 & 106 & 8 \\ 20 & 000522 & 000522.20 & 216 & 235 & 50 \\ 23 & 000513 & 000513.23 & 53 & 106 & 48 \\ 25 & 000512 & 000512.25 & 27 & 52 & 13 \\ 26 & 000512 & 000512.26 & 45 & 52 & 13 \\ 39 & 000512 & 000512.39 & 45 & 52 & 5 \\ 41 & 000511 & 000511.41 & 28 & 30 & 91 \\ 49 & 000522 & 000522.49 & 21 & 235 & 99 \\ 50 & 000514 & 000514.50 & 3 & 46 & 6 \\ 50 & 000522 & 000522.50 & 3 & 238 & 8 \\ 61 & 000511 & 000511.61 & 48 & 51 & 26 \\ 71 & 000522 & 000522.71 & 216 & 235 & 45 \\ 76 & 000512 & 000512.76 & 28 & 51 & 46 \\ 76 & 000522 & 000522.76 & 214 & 287 & 26 \\ 77 & 000512 & 000512.77 & 28 & 51 & 51\end{array}$




\section{Table A-5. Time Sampled by Sampling Period during May 2000}

Sample Period

Total Possible Sampling Time

(hours)

Total Actual Sampling Time

Total Sampling Time with Validated and Verified Samples

Sampling Time (percent of total possible hours)

Sampling Time (percent of total possible hours with validated and verified samples) $\begin{array}{llll}\text { May } 2000 & 000508 & 000511 & 000512\end{array}$

33714

32389

31380

17711

16990

96

100

93

96

00511

000513

1685

00051

1103

000522

11702

685

685

664

640

1499

1292

1051

1048

10779

10725

95

95

86

89

95

92

83

77

95

92 
Table A-6. 2000 Quarter 2 Samples

\begin{tabular}{|c|c|c|c|}
\hline Site ID & Site Name & Sample ID & $\begin{array}{l}\text { Air Volume } \\
\mathbf{m}^{3}\end{array}$ \\
\hline 01 & Española & 00Q2.01 & 12423 \\
\hline 03 & Santa Fe & 00Q2.03 & 11961 \\
\hline 04 & Barranca School & 00Q2.04 & 13126 \\
\hline 05 & Urban Park & 00Q2.05 & 11458 \\
\hline 06 & 48th Street (Twin Tanks Complex) & 00Q2.06 & 13214 \\
\hline 07 & Gulf/Exxon/Shell Station & 00Q2.07 & 10278 \\
\hline 08 & McDonalds & 00Q2.08 & 12914 \\
\hline 09 & Los Alamos Airport & 00Q2.09 & 13154 \\
\hline 10 & Eastgate & 00Q2.10 & 10554 \\
\hline 11 & Well PM-1 (E. Jemez Road) & 00Q2.11 & 12287 \\
\hline 12 & Royal Crest Trailer Court & 00Q2.12 & 12380 \\
\hline 13 & Rocket Park (formerly Piñon School) & 00Q2.13 & 13355 \\
\hline 14 & Pajarito Acres & 00Q2.14 & 13428 \\
\hline 15 & White Rock Fire Station & 00Q2.15 & 12642 \\
\hline 16 & White Rock Nazarene Church & 00Q2.16 & 12848 \\
\hline 17 & Bandelier Fire Lookout (near park entrance) & 00Q2.17 & 13466 \\
\hline 20 & TA-21 Area B & 00Q2.20 & 12620 \\
\hline 23 & TA-5 (formerly TA-52, Beta Site) & 00Q2.23 & 12820 \\
\hline 25 & TA-16-450 & 00Q2.25 & 12993 \\
\hline 26 & TA-49 & 00Q2.26 & 13081 \\
\hline 27 & TA-54 Area G (by QA) & 00Q2.27 & 12560 \\
\hline 30 & Pajarito Booster 2 (P-2) & 00Q2.30 & 12099 \\
\hline 31 & TA-3 & 00Q2.31 & 12993 \\
\hline 32 & Los Alamos County Landfill & 00Q2.32 & 9945 \\
\hline 34 & TA-54 Area G-1 (behind trailer) & 00Q2.34 & 12687 \\
\hline 35 & TA-54 Area G-2 (back fence) & 00Q2.35 & 13059 \\
\hline 36 & TA-54 Area G-3 (by office) & 00Q2.36 & 13206 \\
\hline 38 & TA-54 Area G-QA (next to \# 27) & 00Q2.38 & 8429 \\
\hline 39 & TA-49-QA (adjacent to \# 26) & 00Q2.39 & 11665 \\
\hline 41 & San Ildefonso Pueblo Plaza & 00Q2.41 & 12848 \\
\hline 45 & TA-54 - Area G/ Southeast Perimeter & 00Q2.45 & 12940 \\
\hline 47 & TA-54 - Area G/ North Perimeter & 00Q2.47 & 12744 \\
\hline 49 & Pajarito Road (TA-36) & 00Q2.49 & 11808 \\
\hline 50 & TA-54 - Area G - expansion & 00Q2.50 & 11057 \\
\hline 51 & TA-54 - Area G - expansion pit & 00Q2.51 & 12977 \\
\hline 54 & TA-33 East & 00Q2.54 & 12743 \\
\hline 55 & Santa Fe West (Buckman Booster \#4) & 00Q2.55 & 12786 \\
\hline 56 & El Rancho & 00Q2.56 & 13024 \\
\hline 59 & Jemez Pueblo - Visitor's Center & 00Q2.59 & 10326 \\
\hline 60 & LA Canyon & 00Q2.60 & 13150 \\
\hline 61 & LA Hospital & 00Q2.61 & 12774 \\
\hline 62 & Crossroads Bible Church (formerly Trinity Bible Church) & 00Q2.62 & 12272 \\
\hline 63 & Monte Rey South & 00Q2.63 & 13733 \\
\hline 66 & Los Alamos Inn - South & 00Q2.66 & 8127 \\
\hline 71 & TA-21.01 (NW Bldg 344) & 00Q2.71 & 12981 \\
\hline 76 & TA-15-41 (formerly -61) & 00Q2.76 & 12504 \\
\hline 77 & TA-36 IJ site & 00Q2.77 & 13332 \\
\hline 78 & TA-15-N & 00Q2.78 & 12637 \\
\hline 90 & Eastgate - Backup & 00Q2.90 & 12710 \\
\hline
\end{tabular}




\begin{tabular}{|c|c|c|c|c|}
\hline Clump ID & Sample Period & Sample Number & Clump Name & $\begin{array}{c}\text { Air Volume } \\
\mathbf{m}^{3}\end{array}$ \\
\hline $\mathrm{CC}$ & 000508 & 000508.CC & White Rock Station Clump & 14260 \\
\hline $\mathrm{CD}$ & 000508 & 000508.CD & LA East Station Clump & 16202 \\
\hline $\mathrm{CE}$ & 000508 & 000508.CE & LA West Station Clump & 13998 \\
\hline $\mathrm{CF}$ & 000508 & 000508.CF & Firing Sites Station Clump & 13813 \\
\hline CG & 000508 & 000508.CG & TA-54, Area G Station Clump & 22361 \\
\hline $\mathrm{CH}$ & 000508 & 000508.CH & On-site Station Clump & 13610 \\
\hline $\mathrm{CK}$ & 000508 & 000508.CK & Regional Station Clump & 13346 \\
\hline $\mathrm{CD}$ & 000511 & 000511.CD & LA East Station Clump & 1421 \\
\hline $\mathrm{CE}$ & 000511 & 000511.CE & LA West Station Clump & 726 \\
\hline $\mathrm{CH}$ & 000511 & 000511.CH & Onsite Station Clump & 334 \\
\hline CK & 000511 & 000511.CK & Regional Station Clump & 1014 \\
\hline $\mathrm{CF}$ & 000512 & 000512.CF & Firing Sites Station Clump & 2322 \\
\hline CG & 000512 & 000512.CG & TA-54, Area G Station Clump & 1721 \\
\hline $\mathrm{CC}$ & 000513 & 000513.CC & White Rock Station Clump & 3381 \\
\hline $\mathrm{CD}$ & 000513 & 000513.CD & LA East Station Clump & 1666 \\
\hline $\mathrm{CE}$ & 000513 & 000513.CE & LA West Station Clump & 1383 \\
\hline $\mathrm{CH}$ & 000513 & 000513.CH & Onsite Station Clump & 1373 \\
\hline $\mathrm{CF}$ & 000514 & 000514.CF & Firing Sites Station Clump & 1239 \\
\hline CG & 000514 & 000514.CG & TA-54, Area G Station Clump & 2429 \\
\hline $\mathrm{CH}$ & 000514 & 000514.CH & Onsite Station Clump & 598 \\
\hline $\mathrm{CC}$ & 000522 & 000522.CC & White Rock Station Clump & 9172 \\
\hline $\mathrm{CD}$ & 000522 & 000522.CD & LA East Station Clump & 10197 \\
\hline $\mathrm{CE}$ & 000522 & 000522.CE & LA West Station Clump & 8805 \\
\hline $\mathrm{CF}$ & 000522 & 000522.CF & Firing Sites Station Clump & 8660 \\
\hline CG & 000522 & 000522.CG & TA-54, Area G Station Clump & 11844 \\
\hline $\mathrm{CH}$ & 000522 & 000522.CH & Onsite Station Clump & 8848 \\
\hline $\mathrm{CK}$ & 000522 & 000522.CK & Regional Station Clump & 9189 \\
\hline
\end{tabular}


Table A-8. Short-term Gross Alpha Concentrations for May 2000 Samples

\begin{tabular}{|c|c|}
\hline Sample ID & Site Name \\
\hline 000511.01 & Española \\
\hline 000511.03 & Santa Fe \\
\hline 000511.04 & Barranca School \\
\hline 000511.05 & Urban Park \\
\hline 000511.06 & 48th Street (Twin Tanks Complex) \\
\hline 000511.07 & Gulf/Exxon/Shell Station \\
\hline 000511.08 & McDonalds \\
\hline 000511.09 & Los Alamos Airport \\
\hline 000511.10 & Eastgate \\
\hline 000511.20 & TA-21 Area B \\
\hline 000511.41 & San Ildefonso Pueblo Plaza \\
\hline 000511.55 & Santa Fe West (Buckman Booster \#4) \\
\hline 000511.56 & El Rancho \\
\hline 000511.61 & LA Hospital \\
\hline 000511.62 & Crossroads Bible Church (formerly Trinity Bible Church) \\
\hline 000511.71 & TA-21.01 (NW Bldg 344) \\
\hline 000512.17 & Bandelier Fire Lookout (near park entrance) \\
\hline 000512.25 & TA-16-450 \\
\hline 000512.26 & TA-49 \\
\hline 000512.27 & TA-54 Area G (by QA) \\
\hline 000512.31 & TA-3 \\
\hline 000512.35 & TA-54 Area G-2 (back fence) \\
\hline 000512.36 & TA-54 Area G-3 (by office) \\
\hline 000512.38 & TA-54 Area G-QA (next to \# 27) \\
\hline 000512.39 & TA-49-QA (adjacent to \# 26) \\
\hline 000512.50 & TA-54 - Area G - expansion \\
\hline 000512.51 & TA-54 - Area G - expansion pit \\
\hline 000512.60 & LA Canyon \\
\hline 000512.76 & TA-15-41 (formerly -61) \\
\hline 000512.77 & TA-36 IJ site \\
\hline 000512.78 & TA-15-N \\
\hline 000513.04 & Barranca School \\
\hline 000513.06 & 48th Street (Twin Tanks Complex) \\
\hline 000513.07 & Gulf/Exxon/Shell Station \\
\hline 000513.08 & McDonalds \\
\hline 000513.09 & Los Alamos Airport \\
\hline 000513.10 & Eastgate \\
\hline 000513.11 & Well PM-1 (E. Jemez Road) \\
\hline 000513.13 & Rocket Park (formerly Piñon School) \\
\hline 000513.14 & Pajarito Acres \\
\hline 000513.15 & White Rock Fire Station \\
\hline 000513.16 & White Rock Nazarene Church \\
\hline 000513.20 & TA-21 Area B \\
\hline 000513.23 & TA-5 (formerly TA-52, Beta Site) \\
\hline 000513.49 & Pajarito Road (TA-36) \\
\hline 000513.61 & LA Hospital \\
\hline 000513.62 & Crossroads Bible Church (formerly Trinity Bible Church) \\
\hline 000513.63 & Monte Rey South \\
\hline 000513.66 & Los Alamos Inn - South \\
\hline 000513.71 & TA-21.01 (NW Bldg 344) \\
\hline 000514.12 & Royal Crest Trailer Court \\
\hline 000514.17 & Bandelier Fire Lookout (near park entrance) \\
\hline 000514.25 & TA-16-450 \\
\hline 000514.26 & TA-49 \\
\hline 000514.27 & TA-54 Area G (by QA) \\
\hline 000514.30 & Pajarito Booster 2 (P-2) \\
\hline 000514.31 & TA-3 \\
\hline
\end{tabular}

\author{
Air Concentration 2s Uncertainty $\left(\mathrm{fCi} / \mathrm{m}^{3}\right)$ \\ $\left(\mathrm{fCi} / \mathrm{m}^{3}\right)$
}

$12.8 \quad 5.7$

$2.7-2.8$

$6.3-3.2$

$13.0 \quad 8.5$

$26.8 \quad 8.5$

$8.4-5.2$

$14.6 \quad 6.5$

$13.6 \quad 6.4$

$8.4-3.4$

$10.0 \quad 4.3$

$\begin{array}{ll}4.3 & 3.7\end{array}$

$3.4 \quad 3.3$

$\begin{array}{ll}3.4 & 2.5 \\ 9.5 & \end{array}$

$9.5 \quad 4.0$

$8.3 \quad 5.2$

$\begin{array}{ll}8.8 & 3.2\end{array}$

$2.1 \quad 2.0$

$14.4 \quad 6.4$

$2.3 \quad 2.2$

$6.7 \quad 3.6$

$6.4-3.2$

3.122 .4

$\begin{array}{ll}5.6 & 3.2\end{array}$

$6.5-3.5$

$\begin{array}{ll}6.4 & 2.5 \\ 6.9 & \end{array}$

$6.9 \quad 3.6$

$5.2-3.0$

$7.3-3.5$

$\begin{array}{ll}0.9 & 2.5 \\ 2.0 & \end{array}$

$2.0-2.9$

$1.4-2.7$

$11.2 \quad 5.0$

$6.9-4.1$

$12.4 \quad 5.5$

$13.2-6.4$

$11.6 \quad 5.3$

14.2

$\begin{array}{ll}4.7 & 2.3 \\ 2.8 & \end{array}$

$2.8 \quad 1.4$

$2.9-1.4$

$\begin{array}{ll}2.5 & 1.8\end{array}$

$0.5-1.5$

$17.9-6.5$

$12.2-5.2$

$4.6 \quad 2.1$

$9.1 \quad 4.5$

$\begin{array}{ll}5.7 & 3.8\end{array}$

$2.3 \quad 1.3$

$\begin{array}{ll}7.9 & 3.7\end{array}$

$13.5-5.6$

$8.4-3.0$

$2.0-2.1$

$1.7-2.1$

$3.1-2.5$

$4.3-2.8$

$6.2-2.6$

$\begin{array}{ll}6.9 & 3.4\end{array}$ 
Table A-8 (cont.)

\begin{tabular}{|c|c|}
\hline Sample ID & Site Name \\
\hline 000514.32 & Los Alamos County Landfill \\
\hline 000514.34 & TA-54 Area G-1 (behind trailer) \\
\hline 000514.35 & TA-54 Area G-2 (back fence) \\
\hline 000514.36 & TA-54 Area G-3 (by office) \\
\hline 000514.38 & TA-54 Area G-QA (next to \# 27) \\
\hline 000514.39 & TA-49-QA (adjacent to \# 26) \\
\hline 000514.45 & TA-54 - Area G/ Southeast Perimeter \\
\hline 000514.47 & TA-54 - Area G/ North Perimeter \\
\hline 000514.51 & TA-54 - Area G - expansion pit \\
\hline 000514.60 & LA Canyon \\
\hline 000514.77 & TA-36 IJ site \\
\hline 000522.01 & Española \\
\hline 000522.03 & Santa Fe \\
\hline 000522.04 & Barranca School \\
\hline 000522.06 & 48th Street (Twin Tanks Complex) \\
\hline 000522.07 & Gulf/Exxon/Shell Station \\
\hline 000522.08 & McDonalds \\
\hline 000522.09 & Los Alamos Airport \\
\hline 000522.10 & Eastgate \\
\hline 000522.11 & Well PM-1 (E. Jemez Road) \\
\hline 000522.12 & Royal Crest Trailer Court \\
\hline 000522.13 & Rocket Park (formerly Piñon School) \\
\hline 000522.14 & Pajarito Acres \\
\hline 000522.15 & White Rock Fire Station \\
\hline 000522.16 & White Rock Nazarene Church \\
\hline 000522.17 & Bandelier Fire Lookout (near park entrance) \\
\hline 000522.20 & TA-21 Area B \\
\hline 000522.23 & TA-5 (formerly TA-52, Beta Site) \\
\hline 000522.25 & TA-16-450 \\
\hline 000522.26 & TA-49 \\
\hline 000522.27 & TA-54 Area G (by QA) \\
\hline 000522.30 & Pajarito Booster 2 (P-2) \\
\hline 000522.31 & TA-3 \\
\hline 000522.32 & Los Alamos County Landfill \\
\hline 000522.34 & TA-54 Area G-1 (behind trailer) \\
\hline 000522.35 & TA-54 Area G-2 (back fence) \\
\hline 000522.36 & TA-54 Area G-3 (by office) \\
\hline 000522.38 & TA-54 Area G-QA (next to \# 27) \\
\hline 000522.39 & TA-49-QA (adjacent to \# 26) \\
\hline 000522.41 & San Ildefonso Pueblo Plaza \\
\hline 000522.45 & TA-54 - Area G/ Southeast Perimeter \\
\hline 000522.47 & TA-54 - Area G/ North Perimeter \\
\hline 000522.51 & TA-54 - Area G - expansion pit \\
\hline 000522.54 & TA-33 East \\
\hline 000522.55 & Santa Fe West (Buckman Booster \#4) \\
\hline 000522.56 & El Rancho \\
\hline 000522.59 & Jemez Pueblo - Visitor's Center \\
\hline 000522.60 & LA Canyon \\
\hline 000522.61 & LA Hospital \\
\hline 000522.62 & Crossroads Bible Church (formerly Trinity Bible Church) \\
\hline 000522.63 & Monte Rey South \\
\hline 000522.66 & Los Alamos Inn - South \\
\hline 000522.71 & TA-21.01 (NW Bldg 344) \\
\hline 000522.76 & TA-15-41 (formerly -61) \\
\hline 000522.77 & TA-36 IJ site \\
\hline 000522.78 & TA-15-N \\
\hline
\end{tabular}

Gross Alpha

Air Concentration

2s Uncertainty (fCi/m3) $\left(\mathrm{fCi} / \mathrm{m}^{3}\right)$

$\begin{array}{ll}5.9 & 2.6\end{array}$

$1.5 \quad 1.9$

$3.3-2.6$

$\begin{array}{ll}3.0 & 2.9\end{array}$

$\begin{array}{ll}4.3 & 2.8\end{array}$

$\begin{array}{ll}4.0 & 2.7 \\ 4.1 & \end{array}$

$4.1-2.6$

$\begin{array}{ll}6.8 & 3.2\end{array}$

$\begin{array}{ll}6.0 & 2.8 \\ 4.9 & \end{array}$

$\begin{array}{ll}4.9 & 2.9\end{array}$

$\begin{array}{ll}7.4 & 3.4\end{array}$

$\begin{array}{ll}7.0 & 0.3\end{array}$

$0.9-0.4$

1.4

$\begin{array}{ll}1.6 & 0.5\end{array}$

$\begin{array}{ll}1.5 & 0.5 \\ 1.4 & 0.5\end{array}$

$1.4 \quad 0.4$

$1.9-0.5$

$\begin{array}{ll}1.6 & 0.5\end{array}$

$1.6-0.5$

$1.6-0.5$

$\begin{array}{ll}1.3 & 0.4\end{array}$

$0.7-0.3$

$0.7-0.3$

$\begin{array}{ll}0.7 & 0.3\end{array}$

$\begin{array}{ll}0.7 .0 & 0.4\end{array}$

$\begin{array}{ll}2.0 & 0.5\end{array}$

$1.5-0.4$

$1.4-0.4$

$1.3-0.4$

$\begin{array}{ll}1.0 & 0.4\end{array}$

0.4

$\begin{array}{ll}1.3 & 0.4\end{array}$

$\begin{array}{ll}1.5 & 0.5\end{array}$

$1.4-0.4$

$\begin{array}{ll}1.2 & 0.4\end{array}$

$\begin{array}{ll}1.1 & 0.4\end{array}$

$1.6-0.5$

$\begin{array}{ll}1.3 & 0.4\end{array}$

$\begin{array}{ll}1.0 & 0.4\end{array}$

$\begin{array}{ll}1.3 & 0.4\end{array}$

$\begin{array}{ll}1.9 & 0.5\end{array}$

$1.1-0.4$

$\begin{array}{ll}0.8 & 0.3\end{array}$

$\begin{array}{ll}0.8 & 0.4\end{array}$

$1.3-0.4$

$\begin{array}{ll}0.8 & 0.3\end{array}$

$1.1-0.4$

$1.3-0.4$

$2.1 \quad 0.5$

0.3

$1.9-0.5$

$\begin{array}{ll}1.9 & 0.5\end{array}$

$\begin{array}{ll}1.6 & 0.5\end{array}$

$\begin{array}{ll}1.8 & 0.5\end{array}$

$\begin{array}{ll}1.8 & 0.5\end{array}$

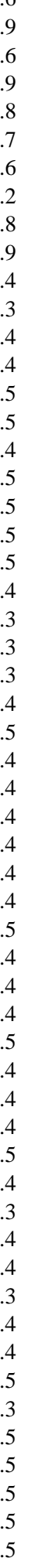




\section{Table A-9. Short-term Gross Beta Concentrations for May 2000 Samples}

\begin{tabular}{|c|c|}
\hline Sample ID & Site Name \\
\hline 000511.01 & Española \\
\hline 000511.03 & Santa Fe \\
\hline 000511.04 & Barranca School \\
\hline 000511.05 & Urban Park \\
\hline 000511.06 & 48th Street (Twin Tanks Complex) \\
\hline 000511.07 & Gulf/Exxon/Shell Station \\
\hline 000511.08 & McDonalds \\
\hline 000511.09 & Los Alamos Airport \\
\hline 000511.10 & Eastgate \\
\hline 000511.20 & TA-21 Area B \\
\hline 000511.41 & San Ildefonso Pueblo Plaza \\
\hline 000511.55 & Santa Fe West (Buckman Booster \#4) \\
\hline 000511.56 & El Rancho \\
\hline 000511.61 & LA Hospital \\
\hline 000511.62 & Crossroads Bible Church (formerly Trinity Bible Church) \\
\hline 000511.71 & TA-21.01 (NW Bldg 344) \\
\hline 000512.17 & Bandelier Fire Lookout (near park entrance) \\
\hline 000512.25 & TA-16-450 \\
\hline 000512.26 & TA-49 \\
\hline 000512.27 & TA-54 Area G (by QA) \\
\hline 000512.31 & TA-3 \\
\hline 000512.35 & TA-54 Area G-2 (back fence) \\
\hline 000512.36 & TA-54 Area G-3 (by office) \\
\hline 000512.38 & TA-54 Area G-QA (next to \# 27) \\
\hline 000512.39 & TA-49-QA (adjacent to \# 26) \\
\hline 000512.50 & TA-54 - Area G - expansion \\
\hline 000512.51 & TA-54 - Area G - expansion pit \\
\hline 000512.60 & LA Canyon \\
\hline 000512.76 & TA-15-41 (formerly -61) \\
\hline 000512.77 & TA-36 IJ site \\
\hline 000512.78 & TA-15-N \\
\hline 000513.04 & Barranca School \\
\hline 000513.06 & 48th Street (Twin Tanks Complex) \\
\hline 000513.07 & Gulf/Exxon/Shell Station \\
\hline 000513.08 & McDonalds \\
\hline 000513.09 & Los Alamos Airport \\
\hline 000513.10 & Eastgate \\
\hline 000513.11 & Well PM-1 (E. Jemez Road) \\
\hline 000513.13 & Rocket Park (formerly Piñon School) \\
\hline 000513.14 & Pajarito Acres \\
\hline 000513.15 & White Rock Fire Station \\
\hline 000513.16 & White Rock Nazarene Church \\
\hline 000513.20 & TA-21 Area B \\
\hline 000513.23 & TA-5 (formerly TA-52, Beta Site) \\
\hline 000513.49 & Pajarito Road (TA-36) \\
\hline 000513.61 & LA Hospital \\
\hline 000513.62 & Crossroads Bible Church (formerly Trinity Bible Church) \\
\hline 000513.63 & Monte Rey South \\
\hline 000513.66 & Los Alamos Inn - South \\
\hline 000513.71 & TA-21.01 (NW Bldg 344) \\
\hline 000514.12 & Royal Crest Trailer Court \\
\hline 000514.17 & Bandelier Fire Lookout (near park entrance) \\
\hline 000514.25 & TA-16-450 \\
\hline 000514.26 & TA-49 \\
\hline 000514.27 & TA-54 Area G (by QA) \\
\hline 000514.30 & Pajarito Booster $2(\mathrm{P}-2)$ \\
\hline
\end{tabular}

\section{Gross Beta}

$\underset{\left(\mathrm{fCi} / \mathrm{m}^{3}\right)}{\operatorname{Air} \text { Concention }} \quad$ 2s Uncertainty

$\begin{array}{ll}22.0 & 6.5 \\ 15.5 & \end{array}$

$15.5-5.1$

$14.9-4.1$

$28.7 \quad 11.4$

$32.5 \quad 8.0$

$40.1 \quad 8.6$

$35.5 \quad 8.1$

$32.5 \quad 8.0$

$15.8-3.9$

$18.3 \quad 4.8$

$13.3 \quad 5.7$

$11.6-5.2$

$13.8 \quad 5.6$

$26.5 \quad 5.1$

$\begin{array}{ll}31.0 & 7.9\end{array}$

$\begin{array}{ll}12.9 & 3.7\end{array}$

$\begin{array}{ll}12.8 & 3.6\end{array}$

$\begin{array}{ll}31.4 & 7.8\end{array}$

$14.5 \quad 4.1$

$20.2 \quad 5.0$

$29.6 \quad 5.0$

$8.6 \quad 3.6$

$14.2 \quad 4.3$

$21.3 \quad 4.9$

$11.9-3.9$

$20.9 \quad 4.9$

$\begin{array}{ll}12.0 & 3.9\end{array}$

$23.2 \quad 4.8$

$9.2 \quad 5.3$

$11.5 \quad 5.4$

$\begin{array}{ll}8.8 & 5.2\end{array}$

$\begin{array}{ll}8.8 .8 & 5.0\end{array}$

$\begin{array}{ll}30.0 & 6.5\end{array}$

$\begin{array}{ll}29.0 & 6.8\end{array}$

$34.2 \quad 8.2$

$26.1 \quad 6.5$

21.4

$14.0 \quad 3.0$

$11.0 \quad 2.1$

$10.9-2.1$

$15.7 \quad 3.2$

$11.0 \quad 3.6$

$20.3 \quad 6.2$

$62.8 \quad 8.4$

$\begin{array}{ll}14.3 & 2.9 \\ 30.3 & 6.4\end{array}$

$30.3-6.4$

26.6

$12.2 \quad 2.2$

$24.7 \quad 5.0$

$23.5 \quad 6.2$

$19.1 \quad 3.5$

$\begin{array}{ll}10.1 & 3.7\end{array}$

$\begin{array}{ll}10.0 & 3.8\end{array}$

$\begin{array}{ll}10.2 & 3.7\end{array}$

$\begin{array}{ll}8.8 & 3.7\end{array}$

$29.4 \quad 4.1$ 
Table A-9 (cont.)

\begin{tabular}{|c|c|}
\hline Sample ID & Site Name \\
\hline 000514.31 & TA-3 \\
\hline 000514.32 & Los Alamos County Landfill \\
\hline 000514.34 & TA-54 Area G-1 (behind trailer) \\
\hline 000514.35 & TA-54 Area G-2 (back fence) \\
\hline 000514.36 & TA-54 Area G-3 (by office) \\
\hline 000514.38 & TA-54 Area G-QA (next to \# 27) \\
\hline 000514.39 & TA-49-QA (adjacent to \# 26) \\
\hline 000514.45 & TA-54 - Area G/ Southeast Perimeter \\
\hline 000514.47 & TA-54 - Area G/ North Perimeter \\
\hline 000514.51 & TA-54 - Area G - expansion pit \\
\hline 000514.60 & LA Canyon \\
\hline 000514.77 & TA-36 IJ site \\
\hline 000522.01 & Española \\
\hline 000522.03 & Santa Fe \\
\hline 000522.04 & Barranca School \\
\hline 000522.06 & 48th Street (Twin Tanks Complex) \\
\hline 000522.07 & Gulf/Exxon/Shell Station \\
\hline 000522.08 & McDonalds \\
\hline 000522.09 & Los Alamos Airport \\
\hline 000522.10 & Eastgate \\
\hline 000522.11 & Well PM-1 (E. Jemez Road) \\
\hline 000522.12 & Royal Crest Trailer Court \\
\hline 000522.13 & Rocket Park (formerly Piñon School) \\
\hline 000522.14 & Pajarito Acres \\
\hline 000522.15 & White Rock Fire Station \\
\hline 000522.16 & White Rock Nazarene Church \\
\hline 000522.17 & Bandelier Fire Lookout (near park entrance) \\
\hline 000522.20 & TA-21 Area B \\
\hline 000522.23 & TA-5 (formerly TA-52, Beta Site) \\
\hline 000522.25 & TA-16-450 \\
\hline 000522.26 & TA-49 \\
\hline 000522.27 & TA-54 Area G (by QA) \\
\hline 000522.30 & Pajarito Booster 2 (P-2) \\
\hline 000522.31 & TA-3 \\
\hline 000522.32 & Los Alamos County Landfill \\
\hline 000522.34 & TA-54 Area G-1 (behind trailer) \\
\hline 000522.35 & TA-54 Area G-2 (back fence) \\
\hline 000522.36 & TA-54 Area G-3 (by office) \\
\hline 000522.38 & TA-54 Area G-QA (next to \# 27) \\
\hline 000522.39 & TA-49-QA (adjacent to \# 26) \\
\hline 000522.41 & San Ildefonso Pueblo Plaza \\
\hline 000522.45 & TA-54 - Area G/ Southeast Perimeter \\
\hline 000522.47 & TA-54 - Area G/ North Perimeter \\
\hline 000522.51 & TA-54 - Area G - expansion pit \\
\hline 000522.54 & TA-33 East \\
\hline 000522.55 & Santa Fe West (Buckman Booster \#4) \\
\hline 000522.56 & El Rancho \\
\hline 000522.59 & Jemez Pueblo - Visitor's Center \\
\hline 000522.60 & LA Canyon \\
\hline 000522.61 & LA Hospital \\
\hline 000522.62 & Crossroads Bible Church (formerly Trinity Bible Church) \\
\hline 000522.63 & Monte Rey South \\
\hline 000522.66 & Los Alamos Inn - South \\
\hline 000522.71 & TA-21.01 (NW Bldg 344) \\
\hline 000522.76 & TA-15-41 (formerly -61) \\
\hline 000522.77 & TA-36 IJ site \\
\hline 000522.78 & TA-15-N \\
\hline
\end{tabular}

Gross Beta
$\begin{gathered}\text { Air Concentration } \\ \left(\mathrm{fCi} / \mathbf{m}^{3}\right)\end{gathered}$

$\begin{array}{ll}10.9 & 3.8\end{array}$

$\begin{array}{ll}24.8 & 3.9\end{array}$

$11.5 \quad 3.7$

$\begin{array}{ll}7.0 & 3.7\end{array}$

$10.3 \quad 4.2$

$\begin{array}{ll}11.0 & 3.9\end{array}$

$\begin{array}{ll}11.4 & 3.8\end{array}$

$\begin{array}{ll}13.1 & 3.7\end{array}$

$14.1 \quad 3.8$

$12.5-4.1$

$\begin{array}{ll}11.5 & 3.9\end{array}$

$13.5-3.9$

$12.5 \quad 0.9$

$\begin{array}{ll}10.1 & 0.8\end{array}$

$\begin{array}{ll}11.3 & 0.8\end{array}$

$\begin{array}{ll}10.9 & 0.9\end{array}$

$\begin{array}{ll}11.8 & 0.9\end{array}$

$\begin{array}{ll}11.8 & 0.9\end{array}$

$\begin{array}{ll}11.9 & 0.9\end{array}$

$11.4-0.9$

$\begin{array}{ll}10.1 & 0.9\end{array}$

$\begin{array}{ll}11.3 & 0.9\end{array}$

$11.5-0.8$

$\begin{array}{ll}10.1 & 0.8\end{array}$

$\begin{array}{ll}10.8 & 0.9\end{array}$

$10.4 \quad 0.8$

$\begin{array}{ll}10.3 & 0.8\end{array}$

$\begin{array}{ll}11.9 & 0.9\end{array}$

$12.6-0.9$

$\begin{array}{ll}11.2 & 0.9\end{array}$

$\begin{array}{ll}10.2 & 0.8\end{array}$

$\begin{array}{ll}10.7 & 0.8\end{array}$

$\begin{array}{ll}12.0 & 0.9\end{array}$

$10.1 \quad 0.9$

12.3

$\begin{array}{ll}11.3 & 0.9\end{array}$

$\begin{array}{ll}9.6 & 0.8\end{array}$

$\begin{array}{ll}9.8 & 0.8\end{array}$

$\begin{array}{ll}10.5 & 0.9\end{array}$

$\begin{array}{ll}10.8 & 0.9\end{array}$

$11.3-0.9$

$\begin{array}{ll}10.9 & 0.8\end{array}$

$\begin{array}{ll}11.0 & 0.8\end{array}$

$\begin{array}{ll}9.8 & 0.8\end{array}$

$\begin{array}{ll}9.8 & 0.8\end{array}$

$\begin{array}{ll}11.3 & 0.8\end{array}$

$\begin{array}{ll}11.3 & 0.8\end{array}$

$11.3-0.9$

$\begin{array}{ll}10.3 & 0.8\end{array}$

$\begin{array}{ll}12.1 & 0.9\end{array}$

$12.6-0.9$

$\begin{array}{ll}10.2 & 0.8\end{array}$

$\begin{array}{ll}11.8 & 0.9\end{array}$

$\begin{array}{ll}12.3 & 0.9\end{array}$

$12.6-1.0$

$\begin{array}{ll}12.1 & 0.9\end{array}$

$\begin{array}{ll}11.5 & 0.9\end{array}$ 
Table A-10. Short-term Gross Alpha and Gross Beta Concentrations above their 3s Uncertainties

\begin{tabular}{|c|c|}
\hline Sample ID & Site Name \\
\hline 000511.01 & Española \\
\hline 000511.03 & Santa Fe \\
\hline 000511.04 & Barranca School \\
\hline 000511.05 & Urban Park \\
\hline 000511.06 & 48th Street (Twin Tanks Complex) \\
\hline 000511.07 & Gulf/Exxon/Shell Station \\
\hline 000511.08 & McDonalds \\
\hline 000511.09 & Los Alamos Airport \\
\hline 000511.10 & Eastgate \\
\hline 000511.20 & TA-21 Area B \\
\hline 000511.41 & San Ildefonso Pueblo Plaza \\
\hline 000511.55 & Santa Fe West (Buckman Booster \#4) \\
\hline 000511.56 & El Rancho \\
\hline 000511.61 & LA Hospital \\
\hline 000511.62 & $\begin{array}{l}\text { Crossroads Bible Church (formerly Trinity Bible } \\
\text { Church) }\end{array}$ \\
\hline 000511.71 & TA-21.01 (NW Bldg 344) \\
\hline 000512.17 & Bandelier Fire Lookout (near park entrance) \\
\hline 000512.25 & TA-16-450 \\
\hline 000512.26 & TA-49 \\
\hline 000512.27 & TA-54 Area G (by QA) \\
\hline 000512.31 & TA-3 \\
\hline 000512.35 & TA-54 Area G-2 (back fence) \\
\hline 000512.36 & TA-54 Area G-3 (by office) \\
\hline 000512.38 & TA-54 Area G-QA (next to \# 27) \\
\hline 000512.39 & TA-49-QA (adjacent to \# 26) \\
\hline 000512.50 & TA-54 - Area G - expansion \\
\hline 000512.51 & TA-54 - Area G - expansion pit \\
\hline 000512.60 & LA Canyon \\
\hline 000512.76 & TA-15-41 (formerly -61) \\
\hline 000512.77 & TA-36 IJ site \\
\hline 000512.78 & TA-15-N \\
\hline 000513.04 & Barranca School \\
\hline 000513.06 & 48th Street (Twin Tanks Complex) \\
\hline 000513.07 & Gulf/Exxon/Shell Station \\
\hline 000513.08 & McDonalds \\
\hline 000513.09 & Los Alamos Airport \\
\hline 000513.10 & Eastgate \\
\hline 000513.11 & Well PM-1 (E. Jemez Road) \\
\hline 000513.13 & Rocket Park (formerly Piñon School) \\
\hline 000513.14 & Pajarito Acres \\
\hline 000513.15 & White Rock Fire Station \\
\hline 000513.16 & White Rock Nazarene Church \\
\hline 000513.20 & TA-21 Area B \\
\hline 000513.23 & TA-5 (formerly TA-52, Beta Site) \\
\hline 000513.49 & Pajarito Road (TA-36) \\
\hline 000513.61 & LA Hospital \\
\hline 000513.62 & $\begin{array}{l}\text { Crossroads Bible Church (formerly Trinity Bible } \\
\text { Church) }\end{array}$ \\
\hline 000513.63 & Monte Rey South \\
\hline 000513.66 & Los Alamos Inn - South \\
\hline 000513.71 & TA-21.01 (NW Bldg 344) \\
\hline 000514.12 & Royal Crest Trailer Court \\
\hline 000514.17 & Bandelier Fire Lookout (near park entrance) \\
\hline 000514.25 & TA-16-450 \\
\hline 000514.26 & TA-49 \\
\hline 000514.27 & TA-54 Area G (by QA) \\
\hline
\end{tabular}

$\begin{array}{cc}\left(\mathbf{f C i} / \mathbf{m}^{3}\right) & \text { Beta Air Concentration } \\ \left(\mathbf{f C i} / \mathbf{m}^{3}\right)\end{array}$

$12.8-22.0$

$26.8-32.5$

$8.4 \quad 40.1$

$14.6 \quad 35.5$

$13.6 \quad 32.5$

$8.4-15.8$

$10.0 \quad 18.3$

13.3

13.8

$9.5-26.5$

$8.3 \quad 31.0$

$\begin{array}{lll}6.8 & 12.9\end{array}$

$\begin{array}{ll}14.4 & 12.8 \\ 31.4\end{array}$

14.5

$\begin{array}{ll}6.7 & 20.2\end{array}$

$6.4 \quad 29.6$

8.6

$\begin{array}{ll}5.6 & 14.2\end{array}$

$6.5 \quad 21.3$

11.9

$\begin{array}{ll}6.9 & 20.9\end{array}$

$5.2-12.0$

$\begin{array}{ll}7.3 & 23.2\end{array}$

9.2

11.5

8.8

$\begin{array}{ll}11.2 & 10.8\end{array}$

$\begin{array}{ll}6.9 & 30.0\end{array}$

$12.4 \quad 29.0$

$13.2 \quad 34.2$

$\begin{array}{ll}11.6 & 26.1\end{array}$

$14.2 \quad 21.4$

$\begin{array}{ll}4.7 & 14.0\end{array}$

$2.8-11.1$

$\begin{array}{ll}2.9 & 10.9\end{array}$

15.7

11.0

$17.9-20.3$

$\begin{array}{ll}12.2 & 62.8\end{array}$

$4.6 \quad 14.3$

$\begin{array}{ll}9.1 & 30.3\end{array}$

$5.7 \quad 26.6$

$2.3 \quad 12.2$

$\begin{array}{ll}7.9 & 24.7\end{array}$

$\begin{array}{ll}13.5 & 23.5\end{array}$

$8.4-19.1$

10.1

10.0

10.2

$\begin{array}{ll}4.3 & 8.8\end{array}$ 
Table A-10 (cont.)

Sample ID Site Name

Alpha Air Concentration $\left(\mathbf{f C i} / \mathbf{m}^{3}\right)$

000514.30

000514.31

000514.32

000514.34

000514.35

000514.36

000514.38

000514.39

000514.45

000514.47

000514.51

000514.60

000514.77

000522.01

000522.03

000522.04

000522.06

000522.07

000522.08

000522.09

000522.10

000522.11

000522.12

000522.13

000522.14

000522.15

000522.16

000522.17

000522.20

000522.23

000522.25

000522.26

000522.27

000522.30

000522.31

000522.32

000522.34

000522.35

000522.36

000522.38

000522.39

000522.41

000522.45

000522.47

000522.51

000522.54

000522.55

000522.56

000522.59

000522.60

000522.61

000522.62

000522.63

000522.66

000522.71

000522.76

000522.77

000522.78
Pajarito Booster 2 (P-2)

TA-3

Los Alamos County Landfill

TA-54 Area G-1 (behind trailer)

TA-54 Area G-2 (back fence)

TA-54 Area G-3 (by office)

TA-54 Area G-QA (next to \# 27)

TA-49-QA (adjacent to \# 26)

TA-54 - Area G/ Southeast Perimeter

TA-54 - Area G/ North Perimeter

TA-54 - Area G - expansion pit

LA Canyon

TA-36 IJ site

Española

Santa Fe

Barranca School

48th Street (Twin Tanks Complex)

Gulf/Exxon/Shell Station

McDonalds

Los Alamos Airport

Eastgate

Well PM-1 (E. Jemez Road)

Royal Crest Trailer Court

Rocket Park (formerly Piñon School)

Pajarito Acres

White Rock Fire Station

White Rock Nazarene Church

Bandelier Fire Lookout (near park entrance)

TA-21 Area B

TA-5 (formerly TA-52, Beta Site)

TA- $16-450$

TA-49

TA-54 Area G (by QA)

Pajarito Booster 2 (P-2)

TA-3

Los Alamos County Landfill

TA-54 Area G-1 (behind trailer)

TA-54 Area G-2 (back fence)

TA-54 Area G-3 (by office)

TA-54 Area G-QA (next to \# 27)

TA-49-QA (adjacent to \# 26)

San Ildefonso Pueblo Plaza

TA-54 - Area G/ Southeast Perimeter

TA-54 - Area G/ North Perimeter

TA-54 - Area G - expansion pit

TA-33 East

Santa Fe West (Buckman Booster \#4)

El Rancho

Jemez Pueblo - Visitor's Center

LA Canyon

LA Hospital

Crossroads Bible Church (formerly Trinity Bible

Church)

Monte Rey South

Los Alamos Inn - South

TA-21.01 (NW Bldg 344)

TA-15-41 (formerly -61)

TA-36 IJ site

TA-15-N
6.2

6.9

5.9

Beta Air Concentration $\left(\mathrm{fCi} / \mathrm{m}^{3}\right)$

29.4

10.9

24.8

11.5

7.0

10.3

11.0

11.4

13.1

14.1

12.5

11.5

13.5

12.5

10.1

11.3

10.9

11.8

11.8

11.9

11.4

10.1

11.3

11.5

10.1

10.8

10.4

10.3

11.9

12.6

11.2

10.2

10.7

12.0

10.1

12.3

11.3

9.6

9.8

10.5

10.9

11.3

10.9

11.0

9.8

11.1

11.3

11.3

11.3

10.3

12.1

12.6

10.2

11.8

12.3

12.6

12.1

11.5 


\section{Table A-11. Biweekly Gross Alpha Concentrations for May 2000 Samples}

\begin{tabular}{|c|c|}
\hline Sample ID & Site Name \\
\hline 000508.01 & Española \\
\hline 000508.03 & Santa Fe \\
\hline 000508.04 & Barranca School \\
\hline 000508.05 & Urban Park \\
\hline 000508.06 & 48th Street (Twin Tanks Complex) \\
\hline 000508.07 & Gulf/Exxon/Shell Station \\
\hline 000508.08 & McDonalds \\
\hline 000508.09 & Los Alamos Airport \\
\hline 000508.11 & Well PM-1 (E. Jemez Road) \\
\hline 000508.12 & Royal Crest Trailer Court \\
\hline 000508.13 & Rocket Park (formerly Piñon School) \\
\hline 000508.14 & Pajarito Acres \\
\hline 000508.15 & White Rock Fire Station \\
\hline 000508.16 & White Rock Nazarene Church \\
\hline 000508.17 & Bandelier Fire Lookout (near park entrance) \\
\hline 000508.20 & TA-21 Area B \\
\hline 000508.23 & TA-5 (formerly TA-52, Beta Site) \\
\hline 000508.25 & TA-16-450 \\
\hline 000508.26 & TA-49 \\
\hline 000508.27 & TA-54 Area G (by QA) \\
\hline 000508.30 & Pajarito Booster 2 (P-2) \\
\hline 000508.31 & TA-3 \\
\hline 000508.32 & Los Alamos County Landfill \\
\hline 000508.34 & TA-54 Area G-1 (behind trailer) \\
\hline 000508.35 & TA-54 Area G-2 (back fence) \\
\hline 000508.36 & TA-54 Area G-3 (by office) \\
\hline 000508.39 & TA-49-QA (adjacent to \# 26) \\
\hline 000508.41 & San Ildefonso Pueblo Plaza \\
\hline 000508.45 & TA-54 - Area G/ Southeast Perimeter \\
\hline 000508.47 & TA-54 - Area G/ North Perimeter \\
\hline 000508.49 & Pajarito Road (TA-36) \\
\hline 000508.50 & TA-54 - Area G - expansion \\
\hline 000508.51 & TA-54 - Area G - expansion pit \\
\hline 000508.54 & TA-33 East \\
\hline 000508.55 & Santa Fe West (Buckman Booster \#4) \\
\hline 000508.56 & El Rancho \\
\hline 000508.59 & Jemez Pueblo - Visitor's Center \\
\hline 000508.60 & LA Canyon \\
\hline 000508.61 & LA Hospital \\
\hline 000508.62 & Crossroads Bible Church (formerly Trinity Bible Church) \\
\hline 000508.63 & Monte Rey South \\
\hline 000508.66 & Los Alamos Inn - South \\
\hline 000508.71 & TA-21.01 (NW Bldg 344) \\
\hline 000508.76 & TA-15-41 (formerly -61) \\
\hline 000508.77 & TA-36 IJ site \\
\hline 000508.78 & TA-15-N \\
\hline 000508.90 & Eastgate - Backup \\
\hline 000522.01 & Espanola \\
\hline 000522.03 & Santa Fe \\
\hline 000522.04 & Barranca School \\
\hline 000522.06 & 48th Street (Twin Tanks Complex) \\
\hline 000522.07 & Gulf/Exxon/Shell Station \\
\hline 000522.08 & McDonalds \\
\hline 000522.09 & Los Alamos Airport \\
\hline 000522.10 & Eastgate \\
\hline
\end{tabular}

\begin{tabular}{|c|c|}
\hline \multicolumn{2}{|c|}{ Gross Alpha } \\
\hline $\begin{array}{l}\text { Air Concentration } \\
\left(\mathrm{fCi} / \mathrm{m}^{3}\right)\end{array}$ & 2s Uncertainty \\
\hline 0.6 & 0.4 \\
\hline 0.6 & 0.4 \\
\hline 0.9 & 0.4 \\
\hline 0.9 & 0.5 \\
\hline 1.5 & 0.6 \\
\hline 0.6 & 0.4 \\
\hline 1.2 & 0.5 \\
\hline 1.1 & 0.5 \\
\hline 1.1 & 0.5 \\
\hline 1.4 & 0.5 \\
\hline 1.3 & 0.5 \\
\hline 0.7 & 0.4 \\
\hline 1.0 & 0.5 \\
\hline 0.8 & 0.4 \\
\hline 1.2 & 0.5 \\
\hline 1.6 & 0.6 \\
\hline 1.0 & 0.5 \\
\hline 1.7 & 0.6 \\
\hline 1.1 & 0.5 \\
\hline 1.1 & 0.5 \\
\hline 0.8 & 0.4 \\
\hline 1.5 & 0.6 \\
\hline 1.2 & 0.6 \\
\hline 1.1 & 0.5 \\
\hline 1.3 & 0.5 \\
\hline 1.7 & 0.6 \\
\hline 1.1 & 0.5 \\
\hline 0.7 & 0.4 \\
\hline 1.6 & 0.5 \\
\hline 1.1 & 0.4 \\
\hline 1.0 & 0.5 \\
\hline 1.2 & 0.5 \\
\hline 0.6 & 0.4 \\
\hline 1.2 & 0.5 \\
\hline 1.1 & 0.5 \\
\hline 1.2 & 0.5 \\
\hline 0.6 & 0.4 \\
\hline 2.2 & 0.8 \\
\hline 1.5 & 0.6 \\
\hline 1.4 & 0.5 \\
\hline 0.9 & 0.4 \\
\hline 1.3 & 0.6 \\
\hline 1.5 & 0.6 \\
\hline 1.4 & 0.5 \\
\hline 1.3 & 0.5 \\
\hline 1.2 & 0.5 \\
\hline 1.6 & 0.6 \\
\hline 2.3 & 0.7 \\
\hline 1.1 & 0.5 \\
\hline 3.0 & 0.7 \\
\hline 6.2 & 1.5 \\
\hline 4.1 & 1.2 \\
\hline 5.1 & 1.4 \\
\hline 5.1 & 1.3 \\
\hline 4.5 & 1.0 \\
\hline
\end{tabular}




\section{Table A-12. Biweekly Gross Beta Concentrations for May 2000 Samples}

\begin{tabular}{|c|c|}
\hline Sample ID & Site Name \\
\hline 000508.01 & Española \\
\hline 000508.03 & Santa Fe \\
\hline 000508.04 & Barranca School \\
\hline 000508.05 & Urban Park \\
\hline 000508.06 & 48th Street (Twin Tanks Complex) \\
\hline 000508.07 & Gulf/Exxon/Shell Station \\
\hline 000508.08 & McDonalds \\
\hline 000508.09 & Los Alamos Airport \\
\hline 000508.11 & Well PM-1 (E. Jemez Road) \\
\hline 000508.12 & Royal Crest Trailer Court \\
\hline 000508.13 & Rocket Park (formerly Piñon School) \\
\hline 000508.14 & Pajarito Acres \\
\hline 000508.15 & White Rock Fire Station \\
\hline 000508.16 & White Rock Nazarene Church \\
\hline 000508.17 & Bandelier Fire Lookout (near park entrance) \\
\hline 000508.20 & TA-21 Area B \\
\hline 000508.23 & TA-5 (formerly TA-52, Beta Site) \\
\hline 000508.25 & TA-16-450 \\
\hline 000508.26 & TA-49 \\
\hline 000508.27 & TA-54 Area G (by QA) \\
\hline 000508.30 & Pajarito Booster 2 (P-2) \\
\hline 000508.31 & TA-3 \\
\hline 000508.32 & Los Alamos County Landfill \\
\hline 000508.34 & TA-54 Area G-1 (behind trailer) \\
\hline 000508.35 & TA-54 Area G-2 (back fence) \\
\hline 000508.36 & TA-54 Area G-3 (by office) \\
\hline 000508.39 & TA-49-QA (adjacent to \# 26) \\
\hline 000508.41 & San Ildefonso Pueblo Plaza \\
\hline 000508.45 & TA-54 - Area G/ Southeast Perimeter \\
\hline 000508.47 & TA-54 - Area G/ North Perimeter \\
\hline 000508.49 & Pajarito Road (TA-36) \\
\hline 000508.50 & TA-54 - Area G - expansion \\
\hline 000508.51 & TA-54 - Area G - expansion pit \\
\hline 000508.54 & TA-33 East \\
\hline 000508.55 & Santa Fe West (Buckman Booster \#4) \\
\hline 000508.56 & El Rancho \\
\hline 000508.59 & Jemez Pueblo - Visitor's Center \\
\hline 000508.60 & LA Canyon \\
\hline 000508.61 & LA Hospital \\
\hline 000508.62 & Crossroads Bible Church (formerly Trinity Bible Church) \\
\hline 000508.63 & Monte Rey South \\
\hline 000508.66 & Los Alamos Inn - South \\
\hline 000508.71 & TA-21.01 (NW Bldg 344) \\
\hline 000508.76 & TA-15-41 (formerly -61) \\
\hline 000508.77 & TA-36 IJ site \\
\hline 000508.78 & TA-15-N \\
\hline 000508.90 & Eastgate - Backup \\
\hline 000522.01 & Española \\
\hline 000522.03 & Santa Fe \\
\hline 000522.04 & Barranca School \\
\hline 000522.06 & 48th Street (Twin Tanks Complex) \\
\hline 000522.07 & Gulf/Exxon/Shell Station \\
\hline 000522.08 & McDonalds \\
\hline 000522.09 & Los Alamos Airport \\
\hline 000522.10 & Eastgate \\
\hline 000522.11 & Well PM-1 (E. Jemez Road) \\
\hline 000522.12 & Royal Crest Trailer Court \\
\hline
\end{tabular}

$\underset{\left(\mathrm{fCi} / \mathrm{m}^{3}\right)}{\operatorname{Air} \text { Concentration }} \quad \begin{gathered}\text { 2s Uncertainty } \\ \left(\mathrm{fCi} / \mathbf{m}^{3}\right)\end{gathered}$

$11.6-1.1$

$10.0-1.0$

$13.5-1.1$

$12.6-1.2$

$12.6-1.2$

$11.2-1.2$

$13.8-1.2$

$14.3-1.2$

$13.1-1.1$

$12.5-1.1$

$14.4-1.2$

$12.9-1.1$

$11.0-1.0$

$14.4-1.2$

$13.9-1.2$

$12.8-1.1$

14.2

$13.3-1.2$

$12.7-1.1$

$12.1-1.1$

$11.9-1.1$

$13.4-1.2$

$11.9-1.2$

$12.7-1.1$

$12.0-1.1$

$10.8 \quad 1.0$

$12.7-1.1$

13.3

$13.1-1.1$

$12.9-1.1$

13.2

$13.5-1.1$

$11.7-1.0$

$13.9-1.1$

$13.6-1.2$

$13.1-1.1$

$11.2-1.0$

$12.2-1.3$

$12.1 \quad 1.3$

$13.9-1.2$

$13.8-1.1$

$11.1-1.2$

$13.2-1.2$

$14.3-1.2$

$13.7 \quad 1.2$

$12.2-1.1$

$13.3-1.1$

$13.6-1.0$

$10.8-1.0$

$11.8-1.0$

$\begin{array}{ll}17.1 & 1.7\end{array}$

$\begin{array}{ll}18.6 & 1.8\end{array}$

$18.7-1.8$

$\begin{array}{ll}17.1 & 1.7\end{array}$

$13.5-1.2$

$11.3-1.1$

$\begin{array}{ll}14.0 & 1.4\end{array}$ 


$\begin{array}{ll}\text { Table A-12 (COnt.) } \\ \text { Sample ID } & \text { Site Name } \\ & \\ 000522.13 & \text { Rocket Park (formerly Piñon School) } \\ 000522.14 & \text { Pajarito Acres } \\ 000522.15 & \text { White Rock Fire Station } \\ 000522.16 & \text { White Rock Nazarene Church } \\ 000522.17 & \text { Bandelier Fire Lookout (near park entrance) } \\ 000522.20 & \text { TA-21 Area B } \\ 000522.23 & \text { TA-5 (formerly TA-52, Beta Site) } \\ 000522.25 & \text { TA-16-450 } \\ 000522.26 & \text { TA-49 } \\ 000522.27 & \text { TA-54 Area G (by QA) } \\ 000522.30 & \text { Pajarito Booster 2 (P-2) } \\ 000522.31 & \text { TA-3 } \\ 000522.32 & \text { Los Alamos County Landfill } \\ 000522.34 & \text { TA-54 Area G-1 (behind trailer) } \\ 000522.35 & \text { TA-54 Area G-2 (back fence) } \\ 000522.36 & \text { TA-54 Area G-3 (by office) } \\ 000522.38 & \text { TA-54 Area G-QA (next to \# 27) } \\ 000522.39 & \text { TA-49-QA (adjacent to \# 26) } \\ 000522.41 & \text { San Ildefonso Pueblo Plaza } \\ 000522.45 & \text { TA-54 - Area G/ Southeast Perimeter } \\ 000522.47 & \text { TA-54 - Area G/ North Perimeter } \\ 000522.51 & \text { TA-54 - Area G - expansion pit } \\ 000522.54 & \text { TA-33 East } \\ 000522.55 & \text { Santa Fe West (Buckman Booster \#4) } \\ 000522.56 & \text { El Rancho } \\ 000522.59 & \text { Jemez Pueblo - Visitor's Center } \\ 000522.60 & \text { LA Canyon } \\ 000522.61 & \text { LA Hospital } \\ 000522.62 & \text { Crossroads Bible Church (formerly Trinity Bible Church) } \\ 000522.63 & \text { Monte Rey South } \\ 000522.66 & \text { Los Alamos Inn - South } \\ 000522.71 & \text { TA-21.01 (NW Bldg 344) } \\ 000522.76 & \text { TA-15-41 (formerly -61) } \\ 000522.77 & \text { TA-36 IJ site } \\ 000522.78 & \text { TA-15-N } \\ & \end{array}$

$\underset{\left(\mathrm{fCi} / \mathrm{m}^{3}\right)}{\text { Air Concentration }} \quad$ 2s Uncertainty

$\begin{array}{ll}11.3 & 0.9\end{array}$

$10.4 \quad 0.9$

$12.3-1.1$

$10.5-0.9$

$10.7 \quad 1.0$

$14.2-1.4$

$21.8-1.7$

$12.9-1.1$

$10.9-1.0$

$11.8-1.1$

$18.1 \quad 1.5$

$13.4-1.2$

$16.6-1.5$

$11.4 \quad 1.0$

$9.1 \quad 0.9$

$10.5-1.0$

$12.2-1.1$

$11.1+1.0$

$11.5-1.0$

$11.3-0.9$

$11.6-1.0$

$10.5-1.0$

$11.1-0.8$

$11.4-1.0$

$11.5-0.9$

$11.3-0.9$

$12.4-1.0$

$16.9-1.4$

17.4

$\begin{array}{ll}10.8 & 0.9\end{array}$

$14.9-1.4$

14.2

$12.2-1.1$

$12.3-1.0$

11.2 


\section{Table A-13. Biweekly Gross Alpha and Gross Beta Concentrations above their 3s Uncertainties}

\begin{tabular}{|c|c|}
\hline Sample ID & Site Name \\
\hline 000508.01 & Española \\
\hline 000508.03 & Santa Fe \\
\hline 000508.04 & Barranca School \\
\hline 000508.05 & Urban Park \\
\hline 000508.06 & 48th Street (Twin Tanks Complex) \\
\hline 000508.07 & Gulf/Exxon/Shell Station \\
\hline 000508.08 & McDonalds \\
\hline 000508.09 & Los Alamos Airport \\
\hline 000508.11 & Well PM-1 (E. Jemez Road) \\
\hline 000508.12 & Royal Crest Trailer Court \\
\hline 000508.13 & Rocket Park (formerly Piñon School) \\
\hline 000508.14 & Pajarito Acres \\
\hline 000508.15 & White Rock Fire Station \\
\hline 000508.16 & White Rock Nazarene Church \\
\hline 000508.17 & Bandelier Fire Lookout (near park entrance) \\
\hline 000508.20 & TA-21 Area B \\
\hline 000508.23 & TA-5 (formerly TA-52, Beta Site) \\
\hline 000508.25 & TA-16-450 \\
\hline 000508.26 & TA-49 \\
\hline 000508.27 & TA-54 Area G (by QA) \\
\hline 000508.30 & Pajarito Booster 2 (P-2) \\
\hline 000508.31 & TA-3 \\
\hline 000508.32 & Los Alamos County Landfill \\
\hline 000508.34 & TA-54 Area G-1 (behind trailer) \\
\hline 000508.35 & TA-54 Area G-2 (back fence) \\
\hline 000508.36 & TA-54 Area G-3 (by office) \\
\hline 000508.39 & TA-49-QA (adjacent to \# 26) \\
\hline 000508.41 & San Ildefonso Pueblo Plaza \\
\hline 000508.45 & TA-54 - Area G/ Southeast Perimeter \\
\hline 000508.47 & TA-54 - Area G/ North Perimeter \\
\hline 000508.49 & Pajarito Road (TA-36) \\
\hline 000508.50 & TA-54 - Area G - expansion \\
\hline 000508.51 & TA-54 - Area G - expansion pit \\
\hline 000508.54 & TA-33 East \\
\hline 000508.55 & Santa Fe West (Buckman Booster \#4) \\
\hline 000508.56 & El Rancho \\
\hline 000508.59 & Jemez Pueblo - Visitor's Center \\
\hline 000508.60 & LA Canyon \\
\hline 000508.61 & LA Hospital \\
\hline 000508.62 & Crossroads Bible Church (formerly Trinity Bible Church) \\
\hline 000508.63 & Monte Rey South \\
\hline 000508.66 & Los Alamos Inn - South \\
\hline 000508.71 & TA-21.01 (NW Bldg 344) \\
\hline 000508.76 & TA-15-41 (formerly -61) \\
\hline 000508.77 & TA-36 IJ site \\
\hline 000508.78 & TA-15-N \\
\hline 000508.90 & Eastgate - Backup \\
\hline 000522.01 & Española \\
\hline 000522.03 & Santa Fe \\
\hline 000522.04 & Barranca School \\
\hline 000522.06 & 48th Street (Twin Tanks Complex) \\
\hline 000522.07 & Gulf/Exxon/Shell Station \\
\hline 000522.08 & McDonalds \\
\hline 000522.09 & Los Alamos Airport \\
\hline
\end{tabular}

Beta Air

Concentration $\left(\mathbf{f C i} / \mathrm{m}^{3}\right)$
11.6

10.0

13.5

12.6

12.6

11.2

13.8

14.3

13.1

12.5

14.4

12.9

11.0

14.5

13.9

12.8

14.2

13.3

12.7

12.1

11.9

13.4

11.9

12.7

12.0

10.8

12.7

13.3

13.1

12.9

13.2

13.5

11.7

13.9

13.6

13.1

11.2

12.2

12.1

13.9

13.8

11.1

13.2

14.3

13.7

12.2

13.3

13.6

10.8

11.8

17.1

18.6

18.7

17.1 
Table A-13 (cont.)

Sample ID Site Name

$\begin{array}{cc}\begin{array}{c}\text { Alpha Air } \\ \text { Concentration } \\ \left.\text { (fCi/m } \mathbf{m}^{3}\right)\end{array} & \begin{array}{r}\text { Beta Air } \\ \text { Concentration } \\ \left(\mathbf{f C i} / \mathbf{m}^{3}\right)\end{array} \\ 4.5 & 13.5 \\ 2.6 & 11.3 \\ 4.0 & 14.0 \\ 1.7 & 11.3 \\ 1.4 & 10.4 \\ 1.3 & 12.3 \\ 0.7 & 10.5 \\ 1.3 & 10.7 \\ 5.7 & 14.2 \\ 3.4 & 21.8 \\ 2.7 & 12.9 \\ 1.7 & 10.9 \\ 2.3 & 11.8 \\ 3.0 & 18.1 \\ 2.9 & 13.4 \\ 3.0 & 16.6 \\ 1.5 & 11.4 \\ 1.8 & 9.1 \\ 2.1 & 10.5 \\ 2.7 & 12.2 \\ 2.1 & 11.1 \\ 1.3 & 11.5 \\ 1.8 & 11.3 \\ 2.7 & 11.6 \\ 2.1 & 10.5 \\ 0.8 & 11.1 \\ 1.3 & 11.4 \\ 1.3 & 11.5 \\ 0.8 & 11.3 \\ 2.5 & 12.4 \\ 3.7 & 16.9 \\ 3.6 & 17.4 \\ 1.4 & 10.8 \\ 3.4 & 14.9 \\ 4.5 & 14.2 \\ 1.5 & 12.2 \\ 2.7 & 12.3 \\ 1.6 & \\ & 11.2\end{array}$

000522.11 Well PM-1 (E. Jemez Road)

$000522.12 \quad$ Royal Crest Trailer Court

000522.13 Rocket Park (formerly Piñon School)

$000522.14 \quad$ Pajarito Acres

000522.15

000522.16

000522.17

White Rock Fire Station

White Rock Nazarene Church

Bandelier Fire Lookout (near park entrance)

TA-21 Area B

000522.23

TA-5 (formerly TA-52, Beta Site)

000522.25

000522.26

000522.27

TA- $16-450$

TA- 49

000522.30

TA-54 Area G (by QA)

000522.31

Pajarito Booster 2 (P-2)

TA-3

000522.32 Los Alamos County Landfill

$000522.34 \quad$ TA-54 Area G-1 (behind trailer)

000522.35

000522.36

TA-54 Area G-2 (back fence)

TA-54 Area G-3 (by office)

000522.38

TA-54 Area G-QA (next to \# 27)

TA-49-QA (adjacent to \# 26)

000522.41 San Ildefonso Pueblo Plaza

000522.45

TA-54 - Area G/ Southeast Perimeter

TA-54 - Area G/ North Perimeter

$000522.51 \quad$ TA-54 - Area G - expansion pit

$000522.54 \quad$ TA-33 East

000522.55

Santa Fe West (Buckman Booster \#4)

El Rancho

Jemez Pueblo - Visitor's Center

000522.60

LA Canyon

LA Hospital

Crossroads Bible Church (formerly Trinity Bible Church)

000522.62

Monte Rey South

000522.63

000522.66

000522.71

000522.76

000522.77

000522.78

Los Alamos Inn - South

TA-21.01 (NW Bldg 344)

TA-15-41 (formerly -61)

TA-36 IJ site

TA-15-N 
Table A-14. Gamma Spectroscopy Measurements for May 2000 Clumps

\begin{tabular}{|c|c|c|c|c|}
\hline Analyte & Sample ID & Clump Name & $\begin{array}{c}\text { Air Concentration } \\
\left(\mathrm{fCi} / \mathrm{m}^{3}\right)\end{array}$ & $\begin{array}{l}\text { 2s Uncertainty } \\
\left(\mathrm{fCi}^{3} / \mathrm{m}^{3}\right)\end{array}$ \\
\hline $\mathrm{Be}-7$ & 000508.CC & White Rock Station Clump & 117 & 12 \\
\hline $\mathrm{Be}-7$ & 000508.CD & LA East Station Clump & 122 & 12 \\
\hline $\mathrm{Be}-7$ & 000508.CE & LA West Station Clump & 92 & 9 \\
\hline $\mathrm{Be}-7$ & 000508.CE & LA West Station Clump & 140 & 14 \\
\hline $\mathrm{Be}-7$ & 000508.CF & Firing Sites Station Clump & 103 & 10 \\
\hline $\mathrm{Be}-7$ & 000508.CG & TA-54, Area G Station Clump & 81 & 8 \\
\hline $\mathrm{Be}-7$ & 000508.CH & Onsite Station Clump & 92 & 9 \\
\hline $\mathrm{Be}-7$ & 000508.CK & Regional Station Clump & 101 & 10 \\
\hline $\mathrm{Be}-7$ & 000511.CD & LA East Station Clump & 105 & 18 \\
\hline $\mathrm{Be}-7$ & 000511.CE & LA West Station Clump & 152 & 27 \\
\hline $\mathrm{Be}-7$ & 000511.CK & Regional Station Clump & 105 & 18 \\
\hline $\mathrm{Be}-7$ & 000512.CF & Firing Sites Station Clump & 115 & 18 \\
\hline $\mathrm{Be}-7$ & 000512.CG & TA-54, Area G Station Clump & 129 & 20 \\
\hline $\mathrm{Be}-7$ & 000512.CG & TA-54, Area G Station Clump & 126 & 20 \\
\hline $\mathrm{Be}-7$ & 000513.CC & White Rock Station Clump & 127 & 14 \\
\hline $\mathrm{Be}-7$ & 000513.CD & LA East Station Clump & 199 & 22 \\
\hline $\mathrm{Be}-7$ & 000513.CE & LA West Station Clump & 183 & 21 \\
\hline $\mathrm{Be}-7$ & 000513.CH & Onsite Station Clump & 182 & 21 \\
\hline $\mathrm{Be}-7$ & 000514.CF & Firing Sites Station Clump & 140 & 18 \\
\hline $\mathrm{Be}-7$ & 000514.CG & TA-54, Area G Station Clump & 117 & 13 \\
\hline $\mathrm{Be}-7$ & 000514.CH & Onsite Station Clump & 123 & 25 \\
\hline $\mathrm{Be}-7$ & 000514.CH & Onsite Station Clump & 219 & 31 \\
\hline $\mathrm{Be}-7$ & 000522.CC & White Rock Station Clump & 129 & 11 \\
\hline $\mathrm{Be}-7$ & 000522.CD & LA East Station Clump & 95 & 8 \\
\hline $\mathrm{Be}-7$ & 000522.CE & LA West Station Clump & 102 & 9 \\
\hline $\mathrm{Be}-7$ & 000522.CF & Firing Sites Station Clump & 94 & 8 \\
\hline $\mathrm{Be}-7$ & 000522.CG & TA-54, Area G Station Clump & 86 & 8 \\
\hline $\mathrm{Be}-7$ & 000522.CH & Onsite Station Clump & 103 & 9 \\
\hline $\mathrm{Be}-7$ & 000522.CK & Regional Station Clump & 134 & 12 \\
\hline $\mathrm{Be}-7$ & 000522.CK & Regional Station Clump & 114 & 10 \\
\hline $\mathrm{Bi}-212$ & 000512.CG & TA-54, Area G Station Clump & 25.7 & 5.3 \\
\hline $\mathrm{K}-40$ & 000508.CD & LA East Station Clump & 4.1 & 1.1 \\
\hline $\mathrm{Pb}-210$ & 000508.CC & White Rock Station Clump & 11.4 & 0.9 \\
\hline $\mathrm{Pb}-210$ & 000508.CD & LA East Station Clump & 11.0 & 0.7 \\
\hline $\mathrm{Pb}-210$ & 000508.CE & LA West Station Clump & 9.2 & 0.7 \\
\hline $\mathrm{Pb}-210$ & 000508.CE & LA West Station Clump & 12.9 & 0.9 \\
\hline $\mathrm{Pb}-210$ & 000508.CF & Firing Sites Station Clump & 9.6 & 0.7 \\
\hline $\mathrm{Pb}-210$ & 000508.CG & TA-54, Area G Station Clump & 7.7 & 0.5 \\
\hline $\mathrm{Pb}-210$ & 000508.CH & Onsite Station Clump & 8.3 & 0.7 \\
\hline $\mathrm{Pb}-210$ & 000508.CK & Regional Station Clump & 8.9 & 0.7 \\
\hline $\mathrm{Pb}-210$ & 000522.CC & White Rock Station Clump & 9.5 & 0.9 \\
\hline $\mathrm{Pb}-210$ & 000522.CD & LA East Station Clump & 6.4 & 0.7 \\
\hline $\mathrm{Pb}-210$ & 000522.CE & LA West Station Clump & 6.9 & 0.8 \\
\hline $\mathrm{Pb}-210$ & 000522.CF & Firing Sites Station Clump & 6.7 & 0.8 \\
\hline $\mathrm{Pb}-210$ & 000522.CG & TA-54, Area G Station Clump & 6.5 & 0.7 \\
\hline $\mathrm{Pb}-210$ & 000522.CH & Onsite Station Clump & 7.1 & 1.0 \\
\hline $\mathrm{Pb}-210$ & 000522.CK & Regional Station Clump & 8.1 & 0.8 \\
\hline $\mathrm{Pb}-210$ & 000522.CK & Regional Station Clump & 9.4 & 0.8 \\
\hline $\mathrm{Pb}-212$ & 000508.CK & Regional Station Clump & 0.9 & 0.1 \\
\hline $\mathrm{Pb}-212$ & 000512.CF & Firing Sites Station Clump & 16.7 & 3.1 \\
\hline $\mathrm{Pb}-212$ & 000512.CG & TA-54, Area G Station Clump & 40.0 & 6.6 \\
\hline $\mathrm{Pb}-212$ & 000522.CC & White Rock Station Clump & 0.6 & 0.2 \\
\hline $\mathrm{Pb}-212$ & 000522.CK & Regional Station Clump & 1.5 & 0.3 \\
\hline Tl-208 & 000512.CG & TA-54, Area G Station Clump & 13.4 & 1.3 \\
\hline
\end{tabular}




\section{Table A-15. Gamma Spectroscopy Measurements above their 3s Uncertainties}

\begin{tabular}{|c|c|c|c|c|c|c|c|}
\hline \multirow[b]{2}{*}{ Sample ID } & \multirow[b]{2}{*}{ Clump Name } & \multicolumn{6}{|c|}{ Air Concentration $\left(\mathrm{f} \mathrm{Ci}^{2} / \mathrm{m}^{3}\right)$} \\
\hline & & Beryllium-7 & Bismuth-212 & Potassium-40 & Lead-210 & Lead-212 & Thallium-208 \\
\hline 000508.CC & $\begin{array}{l}\text { White Rock Station } \\
\text { Clump }\end{array}$ & 117 & & & 11 & & \\
\hline 000508.CD & LA East Station Clump & 122 & & 4 & 11 & & \\
\hline 000508.CE & LA West Station Clump & 116 & & & 11 & & \\
\hline 000508.CF & $\begin{array}{l}\text { Firing Sites Station } \\
\text { Clump }\end{array}$ & 103 & & & 10 & & \\
\hline 000508.CG & $\begin{array}{l}\text { TA-54, Area G Station } \\
\text { Clump }\end{array}$ & 81 & & & 8 & & \\
\hline 000508.CH & Onsite Station Clump & 92 & & & 8 & & \\
\hline 000508.CK & Regional Station Clump & 101 & & & 9 & 1 & \\
\hline 000511.CD & LA East Station Clump & 105 & & & & & \\
\hline 000511.CE & LA West Station Clump & 152 & & & & & \\
\hline 000511.CK & Regional Station Clump & 105 & & & & & \\
\hline 000512.CF & $\begin{array}{l}\text { Firing Sites Station } \\
\text { Clump }\end{array}$ & 115 & & & & 17 & \\
\hline 000512.CG & $\begin{array}{l}\text { TA-54, Area G Station } \\
\text { Clump }\end{array}$ & 128 & 26 & & & 40 & 13 \\
\hline 000513.CC & $\begin{array}{l}\text { White Rock Station } \\
\text { Clump }\end{array}$ & 127 & & & & & \\
\hline 000513.CD & LA East Station Clump & 199 & & & & & \\
\hline 000513.CE & LA West Station Clump & 183 & & & & & \\
\hline 000513.CH & Onsite Station Clump & 182 & & & & & \\
\hline 000514.CF & $\begin{array}{l}\text { Firing Sites Station } \\
\text { Clump }\end{array}$ & 140 & & & & & \\
\hline 000514.CG & $\begin{array}{l}\text { TA-54, Area G Station } \\
\text { Clump }\end{array}$ & 117 & & & & & \\
\hline 000514.CH & Onsite Station Clump & 171 & & & & & \\
\hline 000522.CC & $\begin{array}{l}\text { White Rock Station } \\
\text { Clump }\end{array}$ & 129 & & & 9 & 1 & \\
\hline 000522.CD & LA East Station Clump & 95 & & & 6 & & \\
\hline 000522.CE & LA West Station Clump & 102 & & & 7 & & \\
\hline 000522.CF & $\begin{array}{l}\text { Firing Sites Station } \\
\text { Clump }\end{array}$ & 94 & & & 7 & & \\
\hline 000522.CG & $\begin{array}{l}\text { TA-54, Area G Station } \\
\text { Clump }\end{array}$ & 86 & & & 7 & & \\
\hline 000522.CH & Onsite Station Clump & 103 & & & 7 & & \\
\hline 000522.CK & Regional Station Clump & 124 & & & 9 & 1 & \\
\hline
\end{tabular}

\section{Air Concentration $\left(\mathbf{f C i} / \mathrm{m}^{3}\right)$}




\section{Table A-16. Biweekly and Short-term Americium-241 Concentrations for May 2000 Samples}

\begin{tabular}{|c|c|}
\hline Sample ID & Site Name \\
\hline 000508.01 & Española \\
\hline 000508.03 & Santa Fe \\
\hline 000508.04 & Barranca School \\
\hline 000508.05 & Urban Park \\
\hline 000508.06 & 48th Street (Twin Tanks Complex) \\
\hline 000508.07 & Gulf/Exxon/Shell Station \\
\hline 000508.08 & McDonalds \\
\hline 000508.09 & Los Alamos Airport \\
\hline 000508.11 & Well PM-1 (E. Jemez Road) \\
\hline 000508.12 & Royal Crest Trailer Court \\
\hline 000508.13 & Rocket Park (formerly Piñon School) \\
\hline 000508.14 & Pajarito Acres \\
\hline 000508.15 & White Rock Fire Station \\
\hline 000508.16 & White Rock Nazarene Church \\
\hline 000508.17 & Bandelier Fire Lookout (near park entrance) \\
\hline 000508.20 & TA-21 Area B \\
\hline 000508.23 & TA-5 (formerly TA-52, Beta Site) \\
\hline 000508.25 & TA-16-450 \\
\hline 000508.26 & TA-49 \\
\hline 000508.27 & TA-54 Area G (by QA) \\
\hline 000508.30 & Pajarito Booster 2 (P-2) \\
\hline 000508.31 & TA-3 \\
\hline 000508.32 & Los Alamos County Landfill \\
\hline 000508.34 & TA-54 Area G-1 (behind trailer) \\
\hline 000508.35 & TA-54 Area G-2 (back fence) \\
\hline 000508.36 & TA-54 Area G-3 (by office) \\
\hline 000508.39 & TA-49-QA (adjacent to \# 26) \\
\hline 000508.41 & San Ildefonso Pueblo Plaza \\
\hline 000508.45 & TA-54 - Area G/ Southeast Perimeter \\
\hline 000508.47 & TA-54 - Area G/ North Perimeter \\
\hline 000508.49 & Pajarito Road (TA-36) \\
\hline 000508.50 & TA-54 - Area G - expansion \\
\hline 000508.51 & TA-54 - Area G - expansion pit \\
\hline 000508.54 & TA-33 East \\
\hline 000508.55 & Santa Fe West (Buckman Booster \#4) \\
\hline 000508.56 & El Rancho \\
\hline 000508.59 & Jemez Pueblo - Visitor's Center \\
\hline 000508.60 & LA Canyon \\
\hline 000508.61 & LA Hospital \\
\hline 000508.62 & Crossroads Bible Church (formerly Trinity Bible Church) \\
\hline 000508.63 & Monte Rey South \\
\hline 000508.66 & Los Alamos Inn - South \\
\hline 000508.71 & TA-21.01 (NW Bldg 344) \\
\hline 000508.76 & TA-15-41 (formerly -61) \\
\hline 000508.77 & TA-36 IJ site \\
\hline 000508.78 & TA-15-N \\
\hline 000508.90 & Eastgate - Backup \\
\hline 000511.01 & Española \\
\hline 000511.03 & Santa Fe \\
\hline 000511.04 & Barranca School \\
\hline 000511.05 & Urban Park \\
\hline 000511.06 & 48th Street (Twin Tanks Complex) \\
\hline 000511.07 & Gulf/Exxon/Shell Station \\
\hline 000511.08 & McDonalds \\
\hline 000511.09 & Los Alamos Airport \\
\hline 000511.10 & Eastgate \\
\hline 000511.20 & TA-21 Area B \\
\hline
\end{tabular}

$\underset{\left(\mathbf{a C i} / \mathbf{m}^{3}\right)}{\operatorname{Air} \text { Concentration }} \quad \begin{gathered}\text { 2s Uncertainty } \\ \left(\mathbf{a C i} / \mathbf{m}^{3}\right)\end{gathered}$

$-7 \quad 15$

$4 \quad 18$

$-9 \quad 14$

$9-18$

$2-16$

$2 \quad 17$

1

$-4 \quad 17$

$4 \quad 17$

$\begin{array}{ll}-1 & 17\end{array}$

$-4 \quad 14$

$11-19$

$-3-16$

9

$11 \quad 19$

7

$2 \quad 16$

$\begin{array}{ll}-3 & 16\end{array}$

$\begin{array}{ll}-4 & 15\end{array}$

316

$1-16$

$-2 \quad 16$

2

$92-29$

$10-19$

$-13$

$-4-14$

$\begin{array}{ll}-1 & 18\end{array}$

3

$-5-12$

$-3 \quad 15$

$\begin{array}{ll}-5 & 14\end{array}$

$-2$

$\begin{array}{ll}9 & 17\end{array}$

$\begin{array}{cc}9 & 22\end{array}$

$-6-15$

216

$\begin{array}{ll}2 & 18\end{array}$

1

2

216

5

$-6 \quad 14$

$-2 \quad 16$

$-2 \quad 15$

$-3-16$

5

$-33-190$

$-90-149$

$18 \quad 118$

$-148-335$

$-120 \quad 193$

$22 \quad 225$

$-38 \quad 209$

$-39-215$

$-59 \quad 96$

$-39 \quad 123$ 
Table A-16 (cont.)

\begin{tabular}{|c|c|}
\hline Sample ID & Site Name \\
\hline 000511.41 & San Ildefonso Pueblo Plaza \\
\hline 000511.55 & Santa Fe West (Buckman Booster \#4) \\
\hline 000511.56 & El Rancho \\
\hline 000511.61 & LA Hospital \\
\hline 000511.62 & Crossroads Bible Church (formerly Trinity Bible Church) \\
\hline 000511.71 & TA-21.01 (NW Bldg 344) \\
\hline 000512.17 & Bandelier Fire Lookout (near park entrance) \\
\hline 000512.25 & TA-16-450 \\
\hline 000512.26 & TA-49 \\
\hline 000512.27 & TA-54 Area G (by QA) \\
\hline 000512.31 & TA-3 \\
\hline 000512.35 & TA-54 Area G-2 (back fence) \\
\hline 000512.36 & TA-54 Area G-3 (by office) \\
\hline 000512.38 & TA-54 Area G-QA (next to \# 27) \\
\hline 000512.39 & TA-49-QA (adjacent to \# 26) \\
\hline 000512.50 & TA-54 - Area G - expansion \\
\hline 000512.51 & TA-54 - Area G - expansion pit \\
\hline 000512.60 & LA Canyon \\
\hline 000512.76 & TA-15-41 (formerly -61) \\
\hline 000512.77 & TA-36 IJ site \\
\hline 000512.78 & TA-15-N \\
\hline 000513.04 & Barranca School \\
\hline 000513.06 & 48th Street (Twin Tanks Complex) \\
\hline 000513.07 & Gulf/Exxon/Shell Station \\
\hline 000513.08 & McDonalds \\
\hline 000513.09 & Los Alamos Airport \\
\hline 000513.10 & Eastgate \\
\hline 000513.11 & Well PM-1 (E. Jemez Road) \\
\hline 000513.13 & Rocket Park (formerly Piñon School) \\
\hline 000513.14 & Pajarito Acres \\
\hline 000513.15 & White Rock Fire Station \\
\hline 000513.16 & White Rock Nazarene Church \\
\hline 000513.20 & TA-21 Area B \\
\hline 000513.23 & TA-5 (formerly TA-52, Beta Site) \\
\hline 000513.49 & Pajarito Road (TA-36) \\
\hline 000513.61 & LA Hospital \\
\hline 000513.62 & Crossroads Bible Church (formerly Trinity Bible Church) \\
\hline 000513.63 & Monte Rey South \\
\hline 000513.66 & Los Alamos Inn - South \\
\hline 000513.71 & TA-21.01 (NW Bldg 344) \\
\hline 000514.12 & Royal Crest Trailer Court \\
\hline 000514.17 & Bandelier Fire Lookout (near park entrance) \\
\hline 000514.25 & TA-16-450 \\
\hline 000514.26 & TA-49 \\
\hline 000514.27 & TA-54 Area G (by QA) \\
\hline 000514.30 & Pajarito Booster 2 (P-2) \\
\hline 000514.31 & TA-3 \\
\hline 000514.32 & Los Alamos County Landfill \\
\hline 000514.34 & TA-54 Area G-1 (behind trailer) \\
\hline 000514.35 & TA-54 Area G-2 (back fence) \\
\hline 000514.36 & TA-54 Area G-3 (by office) \\
\hline 000514.38 & TA-54 Area G-QA (next to \# 27) \\
\hline 000514.39 & TA-49-QA (adjacent to \# 26) \\
\hline 000514.45 & TA-54 - Area G/ Southeast Perimeter \\
\hline 000514.47 & TA-54 - Area G/ North Perimeter \\
\hline 000514.51 & TA-54 - Area G - expansion pit \\
\hline 000514.60 & LA Canyon \\
\hline 000514.77 & TA-36 IJ site \\
\hline
\end{tabular}

Air Concentration

$\left(\mathbf{a C i} / \mathbf{m}^{3}\right)$

${ }^{241} \mathrm{Am}$

2s Uncertainty $\left(\mathrm{aCi} / \mathrm{m}^{3}\right)$

173

$-41 \quad 161$

$-105 \quad 161$

$33-130$

$\begin{array}{ll}-99 & 204\end{array}$

$41 \quad 123$

$-36-108$

$-2 \quad 202$

$-67-108$

$36-145$

$-27-112$

$-47-127$

125

$92 \quad 165$

$\begin{array}{ll}-34 & 109\end{array}$

$56-165$

$-21-127$

$12 \quad 127$

$-34-184$

$38 \quad 196$

$-13-184$

$-47-153$

$-76 \quad 163$

$-2 \quad 184$

$-88 \quad 211$

$57-187$

$52 \quad 178$

$-40 \quad 71$

$30-55$

$-15-48$

$-5$

$-50-97$

$58-191$

$71-181$

$-25-68$

$-37 \quad 157$

$-56 \quad 150$

$-23-50$

$-8-130$

$8-175$

$\begin{array}{ll}-24 & 78\end{array}$

$-48 \quad 107$

$-15 \quad 119$

$-54 \quad 112$

$5 \quad 126$

$17 \quad 85$

$25-119$

$17-88$

$36 \quad 119$

$-58-118$

$-93-118$

$-35-126$

$-46-112$

$\begin{array}{ll}-37 & 97\end{array}$

$-1 \quad 108$

$-29 \quad 118$

$-1 \quad 122$

$\begin{array}{ll}-76 & 102\end{array}$ 


\section{Table A-17. Biweekly and Short-term Plutonium-238 Concentrations for May 2000 Samples}

\begin{tabular}{|c|c|}
\hline Sample ID & Site Name \\
\hline 000508.01 & Española \\
\hline 000508.03 & Santa Fe \\
\hline 000508.04 & Barranca School \\
\hline 000508.05 & Urban Park \\
\hline 000508.06 & 48th Street (Twin Tanks Complex) \\
\hline 000508.07 & Gulf/Exxon/Shell Station \\
\hline 000508.08 & McDonalds \\
\hline 000508.09 & Los Alamos Airport \\
\hline 000508.11 & Well PM-1 (E. Jemez Road) \\
\hline 000508.12 & Royal Crest Trailer Court \\
\hline 000508.13 & Rocket Park (formerly Piñon School) \\
\hline 000508.14 & Pajarito Acres \\
\hline 000508.15 & White Rock Fire Station \\
\hline 000508.16 & White Rock Nazarene Church \\
\hline 000508.17 & Bandelier Fire Lookout (near park entrance) \\
\hline 000508.20 & TA-21 Area B \\
\hline 000508.23 & TA-5 (formerly TA-52, Beta Site) \\
\hline 000508.25 & TA-16-450 \\
\hline 000508.26 & TA-49 \\
\hline 000508.27 & TA-54 Area G (by QA) \\
\hline 000508.30 & Pajarito Booster 2 (P-2) \\
\hline 000508.31 & TA-3 \\
\hline 000508.32 & Los Alamos County Landfill \\
\hline 000508.34 & TA-54 Area G-1 (behind trailer) \\
\hline 000508.35 & TA-54 Area G-2 (back fence) \\
\hline 000508.36 & TA-54 Area G-3 (by office) \\
\hline 000508.39 & TA-49-QA (adjacent to \# 26) \\
\hline 000508.41 & San Ildefonso Pueblo Plaza \\
\hline 000508.45 & TA-54 - Area G/ Southeast Perimeter \\
\hline 000508.47 & TA-54 - Area G/ North Perimeter \\
\hline 000508.49 & Pajarito Road (TA-36) \\
\hline 000508.50 & TA-54 - Area G - expansion \\
\hline 000508.51 & TA-54 - Area G - expansion pit \\
\hline 000508.54 & TA-33 East \\
\hline 000508.55 & Santa Fe West (Buckman Booster \#4) \\
\hline 000508.56 & El Rancho \\
\hline 000508.59 & Jemez Pueblo - Visitor's Center \\
\hline 000508.60 & LA Canyon \\
\hline 000508.61 & LA Hospital \\
\hline 000508.62 & Crossroads Bible Church (formerly Trinity Bible Church) \\
\hline 000508.63 & Monte Rey South \\
\hline 000508.66 & Los Alamos Inn - South \\
\hline 000508.71 & TA-21.01 (NW Bldg 344) \\
\hline 000508.76 & TA-15-41 (formerly -61) \\
\hline 000508.77 & TA-36 IJ site \\
\hline 000508.78 & TA-15-N \\
\hline 000508.90 & Eastgate - Backup \\
\hline 000511.01 & Española \\
\hline 000511.03 & Santa Fe \\
\hline 000511.04 & Barranca School \\
\hline 000511.05 & Urban Park \\
\hline 000511.06 & 48th Street (Twin Tanks Complex) \\
\hline 000511.07 & Gulf/Exxon/Shell Station \\
\hline 000511.08 & McDonalds \\
\hline 000511.09 & Los Alamos Airport \\
\hline 000511.10 & Eastgate \\
\hline 000511.20 & TA-21 Area B \\
\hline 000511.41 & San Ildefonso Pueblo Plaza \\
\hline
\end{tabular}

$\underset{\left(\mathrm{aCi} / \mathrm{m}^{3}\right)}{\operatorname{Air} \text { Concentration }} \underset{\left(\mathrm{aCi} / \mathrm{m}^{3}\right)}{\text { 2s Uncertainty }}$

$-2 \quad 5$

126

2

$-1-4$

6

5 
Table A-17 (cont.)

\begin{tabular}{|c|c|}
\hline Sample ID & Site Name \\
\hline 000511.55 & Santa Fe West (Buckman Booster \#4) \\
\hline 000511.56 & El Rancho \\
\hline 000511.61 & LA Hospital \\
\hline 000511.62 & Crossroads Bible Church (formerly Trinity Bible Church) \\
\hline 000511.71 & TA-21.01 (NW Bldg 344) \\
\hline 000512.17 & Bandelier Fire Lookout (near park entrance) \\
\hline 000512.25 & TA-16-450 \\
\hline 000512.26 & TA-49 \\
\hline 000512.27 & TA-54 Area G (by QA) \\
\hline 000512.31 & TA-3 \\
\hline 000512.35 & TA-54 Area G-2 (back fence) \\
\hline 000512.36 & TA-54 Area G-3 (by office) \\
\hline 000512.38 & TA-54 Area G-QA (next to \# 27) \\
\hline 000512.39 & TA-49-QA (adjacent to \# 26) \\
\hline 000512.50 & TA-54 - Area G - expansion \\
\hline 000512.51 & TA-54 - Area G - expansion pit \\
\hline 000512.60 & LA Canyon \\
\hline 000512.76 & TA-15-41 (formerly -61) \\
\hline 000512.77 & TA-36 IJ site \\
\hline 000512.78 & TA-15-N \\
\hline 000513.04 & Barranca School \\
\hline 000513.06 & 48th Street (Twin Tanks Complex) \\
\hline 000513.07 & Gulf/Exxon/Shell Station \\
\hline 000513.08 & McDonalds \\
\hline 000513.09 & Los Alamos Airport \\
\hline 000513.10 & Eastgate \\
\hline 000513.11 & Well PM-1 (E. Jemez Road) \\
\hline 000513.13 & Rocket Park (formerly Piñon School) \\
\hline 000513.14 & Pajarito Acres \\
\hline 000513.15 & White Rock Fire Station \\
\hline 000513.16 & White Rock Nazarene Church \\
\hline 000513.20 & TA-21 Area B \\
\hline 000513.23 & TA-5 (formerly TA-52, Beta Site) \\
\hline 000513.49 & Pajarito Road (TA-36) \\
\hline 000513.61 & LA Hospital \\
\hline 000513.62 & Crossroads Bible Church (formerly Trinity Bible Church) \\
\hline 000513.63 & Monte Rey South \\
\hline 000513.66 & Los Alamos Inn - South \\
\hline 000513.71 & TA-21.01 (NW Bldg 344) \\
\hline 000514.12 & Royal Crest Trailer Court \\
\hline 000514.17 & Bandelier Fire Lookout (near park entrance) \\
\hline 000514.25 & TA- $16-450$ \\
\hline 000514.26 & TA-49 \\
\hline 000514.27 & TA-54 Area G (by QA) \\
\hline 000514.30 & Pajarito Booster $2(\mathrm{P}-2)$ \\
\hline 000514.31 & TA-3 \\
\hline 000514.32 & Los Alamos County Landfill \\
\hline 000514.34 & TA-54 Area G-1 (behind trailer) \\
\hline 000514.35 & TA-54 Area G-2 (back fence) \\
\hline 000514.36 & TA-54 Area G-3 (by office) \\
\hline 000514.38 & TA-54 Area G-QA (next to \# 27) \\
\hline 000514.39 & TA-49-QA (adjacent to \# 26) \\
\hline 000514.45 & TA-54 - Area G/ Southeast Perimeter \\
\hline 000514.47 & TA-54 - Area G/ North Perimeter \\
\hline 000514.51 & TA-54 - Area G - expansion pit \\
\hline 000514.60 & LA Canyon \\
\hline 000514.77 & TA-36 IJ site \\
\hline
\end{tabular}

Air Concentration

$\left(\mathrm{aCi} / \mathrm{m}^{3}\right)$

${ }^{238} \mathrm{Pu}$

$-7$

$-7$

9

$-57$

$-28$

7

3

$-31$

24

$-30$

2

44

9

15

9

8

2

$-8$

-8
-7

$-18$

$-34$

$-16$

23

65

22

57

1

$-7$

1

$-12$

$-18$ 2s Uncertainty $\left(\mathrm{aCi} / \mathrm{m}^{3}\right)$

59

63

42

74

37

35

71

40

58

63

39

63

44

65

45

39

67

65

62

64

56

92

99

122

60

90

27

17

18

20

37

99

56

25

55

90

40

69

59

28

41

40

40

42

27

42

28

38

43

47

47

64

35

45

42

40

62 


\section{Table A-18. Biweekly and Short-term Plutonium-239 Concentrations for May 2000 Samples}

\begin{tabular}{|c|c|}
\hline Sample ID & Site Name \\
\hline 000508.01 & Española \\
\hline 000508.03 & Santa Fe \\
\hline 000508.04 & Barranca School \\
\hline 000508.05 & Urban Park \\
\hline 000508.06 & 48th Street (Twin Tanks Complex) \\
\hline 000508.07 & Gulf/Exxon/Shell Station \\
\hline 000508.08 & McDonalds \\
\hline 000508.09 & Los Alamos Airport \\
\hline 000508.11 & Well PM-1 (E. Jemez Road) \\
\hline 000508.12 & Royal Crest Trailer Court \\
\hline 000508.13 & Rocket Park (formerly Piñon School) \\
\hline 000508.14 & Pajarito Acres \\
\hline 000508.15 & White Rock Fire Station \\
\hline 000508.16 & White Rock Nazarene Church \\
\hline 000508.17 & Bandelier Fire Lookout (near park entrance) \\
\hline 000508.20 & TA-21 Area B \\
\hline 000508.23 & TA-5 (formerly TA-52, Beta Site) \\
\hline 000508.25 & TA-16-450 \\
\hline 000508.26 & TA-49 \\
\hline 000508.27 & TA-54 Area G (by QA) \\
\hline 000508.30 & Pajarito Booster 2 (P-2) \\
\hline 000508.31 & TA-3 \\
\hline 000508.32 & Los Alamos County Landfill \\
\hline 000508.34 & TA-54 Area G-1 (behind trailer) \\
\hline 000508.35 & TA-54 Area G-2 (back fence) \\
\hline 000508.36 & TA-54 Area G-3 (by office) \\
\hline 000508.39 & TA-49-QA (adjacent to \# 26) \\
\hline 000508.41 & San Ildefonso Pueblo Plaza \\
\hline 000508.45 & TA-54 - Area G/ Southeast Perimeter \\
\hline 000508.47 & TA-54 - Area G/ North Perimeter \\
\hline 000508.49 & Pajarito Road (TA-36) \\
\hline 000508.50 & TA-54 - Area G - expansion \\
\hline 000508.51 & TA-54 - Area G - expansion pit \\
\hline 000508.54 & TA-33 East \\
\hline 000508.55 & Santa Fe West (Buckman Booster \#4) \\
\hline 000508.56 & El Rancho \\
\hline 000508.59 & Jemez Pueblo - Visitor's Center \\
\hline 000508.60 & LA Canyon \\
\hline 000508.61 & LA Hospital \\
\hline 000508.62 & Crossroads Bible Church (formerly Trinity Bible Church) \\
\hline 000508.63 & Monte Rey South \\
\hline 000508.66 & Los Alamos Inn - South \\
\hline 000508.71 & TA-21.01 (NW Bldg 344) \\
\hline 000508.76 & TA-15-41 (formerly -61) \\
\hline 000508.77 & TA-36 IJ site \\
\hline 000508.78 & TA-15-N \\
\hline 000508.90 & Eastgate - Backup \\
\hline 000511.01 & Española \\
\hline 000511.03 & Santa Fe \\
\hline 000511.04 & Barranca School \\
\hline 000511.05 & Urban Park \\
\hline 000511.06 & 48th Street (Twin Tanks Complex) \\
\hline 000511.07 & Gulf/Exxon/Shell Station \\
\hline 000511.08 & McDonalds \\
\hline 000511.09 & Los Alamos Airport \\
\hline 000511.10 & Eastgate \\
\hline 000511.20 & TA-21 Area B \\
\hline
\end{tabular}

2s Uncertainty $\left(\mathbf{a C i} / \mathbf{m}^{3}\right)$

12.3

16.3

14.4

9.2

11.4

12.9

12.3

12.0

12.4

15.2

14.7

11.7

11.7

14.4

11.9

18.4

13.6

11.6

11.5

15.4

11.6

13.5

10.6

16.4

9.6

12.9

9.8

12.9

9.7

10.0

9.9

11.4

13.5

10.5

16.6

12.3

11.7

11.8

11.8

15.1

11.4

18.7

14.0

12.3

10.9

11.9

12.0

145.3

151.3

91.7

287.6

165.1

170.3

166.0

208.4

99.6

104.4 
Table A-18 (cont.)

${ }^{239} \mathrm{Pu}$

\begin{tabular}{|c|c|}
\hline Sample ID & Site Name \\
\hline 000511.41 & San Ildefonso Pueblo Plaza \\
\hline 000511.55 & Santa Fe West (Buckman Booster \#4) \\
\hline 000511.56 & El Rancho \\
\hline 000511.61 & LA Hospital \\
\hline 000511.62 & Crossroads Bible Church (formerly Trinity Bible Church) \\
\hline 000511.71 & TA-21.01 (NW Bldg 344) \\
\hline 000512.17 & Bandelier Fire Lookout (near park entrance) \\
\hline 000512.25 & TA-16-450 \\
\hline 000512.26 & TA-49 \\
\hline 000512.27 & TA-54 Area G (by QA) \\
\hline 000512.31 & TA-3 \\
\hline 000512.35 & TA-54 Area G-2 (back fence) \\
\hline 000512.36 & TA-54 Area G-3 (by office) \\
\hline 000512.38 & TA-54 Area G-QA (next to \# 27) \\
\hline 000512.39 & TA-49-QA (adjacent to \# 26) \\
\hline 000512.50 & TA-54 - Area G - expansion \\
\hline 000512.51 & TA-54 - Area G - expansion pit \\
\hline 000512.60 & LA Canyon \\
\hline 000512.76 & TA-15-41 (formerly -61) \\
\hline 000512.77 & TA-36 IJ site \\
\hline 000512.78 & TA-15-N \\
\hline 000513.04 & Barranca School \\
\hline 000513.06 & 48th Street (Twin Tanks Complex) \\
\hline 000513.07 & Gulf/Exxon/Shell Station \\
\hline 000513.08 & McDonalds \\
\hline 000513.09 & Los Alamos Airport \\
\hline 000513.10 & Eastgate \\
\hline 000513.11 & Well PM-1 (E. Jemez Road) \\
\hline 000513.13 & Rocket Park (formerly Piñon School) \\
\hline 000513.14 & Pajarito Acres \\
\hline 000513.15 & White Rock Fire Station \\
\hline 000513.16 & White Rock Nazarene Church \\
\hline 000513.20 & TA-21 Area B \\
\hline 000513.23 & TA-5 (formerly TA-52, Beta Site) \\
\hline 000513.49 & Pajarito Road (TA-36) \\
\hline 000513.61 & LA Hospital \\
\hline 000513.62 & Crossroads Bible Church (formerly Trinity Bible Church) \\
\hline 000513.63 & Monte Rey South \\
\hline 000513.66 & Los Alamos Inn - South \\
\hline 000513.71 & TA-21.01 (NW Bldg 344) \\
\hline 000514.12 & Royal Crest Trailer Court \\
\hline 000514.17 & Bandelier Fire Lookout (near park entrance) \\
\hline 000514.25 & TA-16-450 \\
\hline 000514.26 & TA-49 \\
\hline 000514.27 & TA-54 Area G (by QA) \\
\hline 000514.30 & Pajarito Booster $2(\mathrm{P}-2)$ \\
\hline 000514.31 & TA-3 \\
\hline 000514.32 & Los Alamos County Landfill \\
\hline 000514.34 & TA-54 Area G-1 (behind trailer) \\
\hline 000514.35 & TA-54 Area G-2 (back fence) \\
\hline 000514.36 & TA-54 Area G-3 (by office) \\
\hline 000514.38 & TA-54 Area G-QA (next to \# 27) \\
\hline 000514.39 & TA-49-QA (adjacent to \# 26) \\
\hline 000514.45 & TA-54 - Area G/ Southeast Perimeter \\
\hline 000514.47 & TA-54 - Area G/ North Perimeter \\
\hline 000514.51 & TA-54 - Area G - expansion pit \\
\hline 000514.60 & LA Canyon \\
\hline 000514.77 & TA-36 IJ site \\
\hline
\end{tabular}

$\underset{\left(\mathbf{a C i} / \mathbf{m}^{3}\right)}{\operatorname{Air} \text { Concentration }}$

27.8

25.5

58.0

86.1

$-28.5$

141.7

$-19.4$

$-4.2$

$-2.3$

79.1

86.3

10.7

53.6

120.0

$-8.9$

33.5

$-15.4$

17.9

27.8

6.5

$-76.4$

$-12.3$

107.5

106.5

106.0

84.8

51.2

11.5

7.2

$-3.9$

$-10.3$

$-26.5$

86.5

159.9

26.8

50.2

5.8

$-18.1$

471.9

44.6

$-19.9$

$-29.0$

73.6

$-8.9$

72.3

2.9

4.2

44.1

$-8.5$

25.8

42.8

4.4

$-66.3$

33.9

27.9

$-30.4$

56.7

22.7 2s Uncertainty

147.4

135.2

144.1

117.6

169.3

125.8

99.6

163.0

91.7

110.6

109.2

86.4

115.0

130.8

91.7

103.4

90.0

94.9

147.4

142.0

145.6

127.4

159.4

172.8

211.7

169.4

127.1

61.1

38.4

39.9

61.1

70.9

140.4

190.2

69.7

153.6

127.0

33.2

202.9

134.7

64.1

77.4

104.9

92.0

117.3

62.5

83.4

79.0

87.5

99.1

106.3

100.2

74.5

85.7

89.0

87.2

113.3

87.5 


\section{Table A-19. Biweekly and Short-term Uranium-234 Concentrations for May 2000 Samples}

\begin{tabular}{|c|c|}
\hline Sample ID & Site Name \\
\hline 000508.01 & Española \\
\hline 000508.03 & Santa Fe \\
\hline 000508.04 & Barranca School \\
\hline 000508.05 & Urban Park \\
\hline 000508.06 & 48th Street (Twin Tanks Complex) \\
\hline 000508.07 & Gulf/Exxon/Shell Station \\
\hline 000508.08 & McDonalds \\
\hline 000508.09 & Los Alamos Airport \\
\hline 000508.11 & Well PM-1 (E. Jemez Road) \\
\hline 000508.12 & Royal Crest Trailer Court \\
\hline 000508.13 & Rocket Park (formerly Piñon School) \\
\hline 000508.14 & Pajarito Acres \\
\hline 000508.15 & White Rock Fire Station \\
\hline 000508.16 & White Rock Nazarene Church \\
\hline 000508.17 & Bandelier Fire Lookout (near park entrance) \\
\hline 000508.20 & TA-21 Area B \\
\hline 000508.23 & TA-5 (formerly TA-52, Beta Site) \\
\hline 000508.25 & TA-16-450 \\
\hline 000508.26 & TA-49 \\
\hline 000508.27 & TA-54 Area G (by QA) \\
\hline 000508.30 & Pajarito Booster 2 (P-2) \\
\hline 000508.31 & TA-3 \\
\hline 000508.32 & Los Alamos County Landfill \\
\hline 000508.34 & TA-54 Area G-1 (behind trailer) \\
\hline 000508.35 & TA-54 Area G-2 (back fence) \\
\hline 000508.36 & TA-54 Area G-3 (by office) \\
\hline 000508.39 & TA-49-QA (adjacent to \# 26) \\
\hline 000508.41 & San Ildefonso Pueblo Plaza \\
\hline 000508.45 & TA-54 - Area G/ Southeast Perimeter \\
\hline 000508.47 & TA-54 - Area G/ North Perimeter \\
\hline 000508.49 & Pajarito Road (TA-36) \\
\hline 000508.50 & TA-54 - Area G - expansion \\
\hline 000508.51 & TA-54 - Area G - expansion pit \\
\hline 000508.54 & TA-33 East \\
\hline 000508.55 & Santa Fe West (Buckman Booster \#4) \\
\hline 000508.56 & El Rancho \\
\hline 000508.59 & Jemez Pueblo - Visitor's Center \\
\hline 000508.60 & LA Canyon \\
\hline 000508.61 & LA Hospital \\
\hline 000508.62 & Crossroads Bible Church (formerly Trinity Bible Church) \\
\hline 000508.63 & Monte Rey South \\
\hline 000508.66 & Los Alamos Inn - South \\
\hline 000508.71 & TA-21.01 (NW Bldg 344) \\
\hline 000508.76 & TA-15-41 (formerly -61) \\
\hline 000508.77 & TA-36 IJ site \\
\hline 000508.78 & TA-15-N \\
\hline 000508.90 & Eastgate - Backup \\
\hline 000511.01 & Española \\
\hline 000511.03 & Santa Fe \\
\hline 000511.04 & Barranca School \\
\hline 000511.05 & Urban Park \\
\hline 000511.06 & 48th Street (Twin Tanks Complex) \\
\hline 000511.07 & Gulf/Exxon/Shell Station \\
\hline 000511.08 & McDonalds \\
\hline 000511.09 & Los Alamos Airport \\
\hline 000511.10 & Eastgate \\
\hline 000511.20 & TA-21 Area B \\
\hline 000511.41 & San Ildefonso Pueblo Plaza \\
\hline
\end{tabular}

\author{
Air Concentration \\ $\left(\mathbf{a C i} / \mathbf{m}^{3}\right)$
}

${ }^{234} \mathbf{U}$
2s Uncertainty $\left(\mathrm{aCi} / \mathrm{m}^{3}\right)$

22

27

18

14

14

21

22

15

19

15

12

18

18

24

18

26

15

17

15

21

14

17

21

29

14

15

13

16

16

27

12

22

18

13

24

22

21

15

14

18

17

15

17

14

15

15

15

172

152

114

291

205

304

250

255

100

130

158 
Table A-19 (cont.)

\begin{tabular}{|c|c|}
\hline Sample ID & Site Name \\
\hline 000511.55 & Santa Fe West (Buckman Booster \#4) \\
\hline 000511.56 & El Rancho \\
\hline 000511.61 & LA Hospital \\
\hline 000511.62 & Crossroads Bible Church (formerly Trinity Bible Church) \\
\hline 000511.71 & TA-21.01 (NW Bldg 344) \\
\hline 000512.17 & Bandelier Fire Lookout (near park entrance) \\
\hline 000512.25 & TA- $16-450$ \\
\hline 000512.26 & TA-49 \\
\hline 000512.27 & TA-54 Area G (by QA) \\
\hline 000512.31 & TA-3 \\
\hline 000512.35 & TA-54 Area G-2 (back fence) \\
\hline 000512.36 & TA-54 Area G-3 (by office) \\
\hline 000512.38 & TA-54 Area G-QA (next to \# 27) \\
\hline 000512.39 & TA-49-QA (adjacent to \# 26) \\
\hline 000512.50 & TA-54 - Area G - expansion \\
\hline 000512.51 & TA-54 - Area G - expansion pit \\
\hline 000512.60 & LA Canyon \\
\hline 000512.76 & TA-15-41 (formerly -61) \\
\hline 000512.77 & TA-36 IJ site \\
\hline 000512.78 & TA-15-N \\
\hline 000513.04 & Barranca School \\
\hline 000513.06 & 48th Street (Twin Tanks Complex) \\
\hline 000513.07 & Gulf/Exxon/Shell Station \\
\hline 000513.08 & McDonalds \\
\hline 000513.09 & Los Alamos Airport \\
\hline 000513.10 & Eastgate \\
\hline 000513.11 & Well PM-1 (E. Jemez Road) \\
\hline 000513.13 & Rocket Park (formerly Piñon School) \\
\hline 000513.14 & Pajarito Acres \\
\hline 000513.15 & White Rock Fire Station \\
\hline 000513.16 & White Rock Nazarene Church \\
\hline 000513.20 & TA-21 Area B \\
\hline 000513.23 & TA-5 (formerly TA-52, Beta Site) \\
\hline 000513.49 & Pajarito Road (TA-36) \\
\hline 000513.61 & LA Hospital \\
\hline 000513.62 & Crossroads Bible Church (formerly Trinity Bible Church) \\
\hline 000513.63 & Monte Rey South \\
\hline 000513.66 & Los Alamos Inn - South \\
\hline 000513.71 & TA-21.01 (NW Bldg 344) \\
\hline 000514.12 & Royal Crest Trailer Court \\
\hline 000514.17 & Bandelier Fire Lookout (near park entrance) \\
\hline 000514.25 & TA- $16-450$ \\
\hline 000514.26 & TA-49 \\
\hline 000514.27 & TA-54 Area G (by QA) \\
\hline 000514.30 & Pajarito Booster 2 (P-2) \\
\hline 000514.31 & TA-3 \\
\hline 000514.32 & Los Alamos County Landfill \\
\hline 000514.34 & TA-54 Area G-1 (behind trailer) \\
\hline 000514.35 & TA-54 Area G-2 (back fence) \\
\hline 000514.36 & TA-54 Area G-3 (by office) \\
\hline 000514.38 & TA-54 Area G-QA (next to \# 27) \\
\hline 000514.39 & TA-49-QA (adjacent to \# 26) \\
\hline 000514.45 & TA-54 - Area G/ Southeast Perimeter \\
\hline 000514.47 & TA-54 - Area G/ North Perimeter \\
\hline 000514.51 & TA-54 - Area G - expansion pit \\
\hline 000514.60 & LA Canyon \\
\hline 000514.77 & TA-36 IJ site \\
\hline
\end{tabular}

$\underset{(\mathrm{aCi} / \mathrm{m3})}{\operatorname{Air} \text { Concentration }} \quad$ 2s $\underset{(\mathrm{aCi} / \mathrm{m} 3)}{\text { Uncertainty }}$

$-4 \quad 141$

$-4 \quad 143$

$92 \quad 119$

$164 \quad 210$

$\begin{array}{ll}75 & 100\end{array}$

$96 \quad 122$

$262 \quad 202$

$102 \quad 138$

$420 \quad 159$

$351 \quad 158$

$43 \quad 94$

$18 \quad 104$

$675 \quad 172$

$148 \quad 138$

$\begin{array}{ll}689 & 179\end{array}$

$311 \quad 136$

$105 \quad 143$

$38 \quad 149$

$87 \quad 176$

$47-181$

$-13 \quad 134$

$227 \quad 231$

$556-251$

$81 \quad 197$

$143 \quad 166$

250

$103 \quad 75$

$26 \quad 40$

$10 \quad 42$

$11 \quad 66$

$46 \quad 90$

$206 \quad 167$

1709

$-42 \quad 70$

192

168

$7 \quad 43$

$199-175$

$342 \quad 321$

$103 \quad 82$

$10 \quad 116$

$18 \quad 97$

$187 \quad 164$

$99-143$

$337-149$

$-22 \quad 92$

455192

$35-109$

$-38 \quad 123$

$35 \quad 160$

$4-107$

$119 \quad 160$

$51 \quad 94$

$45-95$

$18 \quad 102$

$115-191$

$10 \quad 132$ 


\section{Table A-20. Biweekly and Short-term Uranium-235 Concentrations for May 2000 Samples}

\begin{tabular}{|c|c|}
\hline Sample ID & Site Name \\
\hline 000508.01 & Española \\
\hline 000508.03 & Santa Fe \\
\hline 000508.04 & Barranca School \\
\hline 000508.05 & Urban Park \\
\hline 000508.06 & 48th Street (Twin Tanks Complex) \\
\hline 000508.07 & Gulf/Exxon/Shell Station \\
\hline 000508.08 & McDonalds \\
\hline 000508.09 & Los Alamos Airport \\
\hline 000508.11 & Well PM-1 (E. Jemez Road) \\
\hline 000508.12 & Royal Crest Trailer Court \\
\hline 000508.13 & Rocket Park (formerly Piñon School) \\
\hline 000508.14 & Pajarito Acres \\
\hline 000508.15 & White Rock Fire Station \\
\hline 000508.16 & White Rock Nazarene Church \\
\hline 000508.17 & Bandelier Fire Lookout (near park entrance) \\
\hline 000508.20 & TA-21 Area B \\
\hline 000508.23 & TA-5 (formerly TA-52, Beta Site) \\
\hline 000508.25 & TA-16-450 \\
\hline 000508.26 & TA-49 \\
\hline 000508.27 & TA-54 Area G (by QA) \\
\hline 000508.30 & Pajarito Booster 2 (P-2) \\
\hline 000508.31 & TA-3 \\
\hline 000508.32 & Los Alamos County Landfill \\
\hline 000508.34 & TA-54 Area G-1 (behind trailer) \\
\hline 000508.35 & TA-54 Area G-2 (back fence) \\
\hline 000508.36 & TA-54 Area G-3 (by office) \\
\hline 000508.39 & TA-49-QA (adjacent to \# 26) \\
\hline 000508.41 & San Ildefonso Pueblo Plaza \\
\hline 000508.45 & TA-54 - Area G/ Southeast Perimeter \\
\hline 000508.47 & TA-54 - Area G/ North Perimeter \\
\hline 000508.49 & Pajarito Road (TA-36) \\
\hline 000508.50 & TA-54 - Area G - expansion \\
\hline 000508.51 & TA-54 - Area G - expansion pit \\
\hline 000508.54 & TA-33 East \\
\hline 000508.55 & Santa Fe West (Buckman Booster \#4) \\
\hline 000508.56 & El Rancho \\
\hline 000508.59 & Jemez Pueblo - Visitor's Center \\
\hline 000508.60 & LA Canyon \\
\hline 000508.61 & LA Hospital \\
\hline 000508.62 & Crossroads Bible Church (formerly Trinity Bible Church) \\
\hline 000508.63 & Monte Rey South \\
\hline 000508.66 & Los Alamos Inn - South \\
\hline 000508.71 & TA-21.01 (NW Bldg 344) \\
\hline 000508.76 & TA-15-41 (formerly -61) \\
\hline 000508.77 & TA-36 IJ site \\
\hline 000508.78 & TA-15-N \\
\hline 000508.90 & Eastgate - Backup \\
\hline 000511.01 & Española \\
\hline 000511.03 & Santa Fe \\
\hline 000511.04 & Barranca School \\
\hline 000511.05 & Urban Park \\
\hline 000511.06 & 48th Street (Twin Tanks Complex) \\
\hline 000511.07 & Gulf/Exxon/Shell Station \\
\hline 000511.08 & McDonalds \\
\hline 000511.09 & Los Alamos Airport \\
\hline 000511.10 & Eastgate \\
\hline 000511.20 & TA-21 Area B \\
\hline 000511.41 & San Ildefonso Pueblo Plaza \\
\hline
\end{tabular}

\author{
Air Concentration \\ $\left(\mathrm{aCi} / \mathrm{m}^{3}\right)$
}

${ }^{235} \mathbf{U}$
Uncertainty
$\left(\mathrm{aCi} / \mathrm{m}^{3}\right)$

12

16

14

13

13

11

12

11

12

12

11

11

11

14

14

12

14

13

14

12

11

14

14

12

10

12

12

12

12

12

11

12

14

12

16

12

14

12

10

15

14

10

13

11

13

11

9

167

111

87

223

157

162

198

161

77

100

133 
Table A-20 (cont.)

\begin{tabular}{|c|c|}
\hline Sample ID & Site Name \\
\hline 000511.55 & Santa Fe West (Buckman Booster \#4) \\
\hline 000511.56 & El Rancho \\
\hline 000511.61 & LA Hospital \\
\hline 000511.62 & Crossroads Bible Church (formerly Trinity Bible Church) \\
\hline 000511.71 & TA-21.01 (NW Bldg 344) \\
\hline 000512.17 & Bandelier Fire Lookout (near park entrance) \\
\hline 000512.25 & TA-16-450 \\
\hline 000512.26 & TA-49 \\
\hline 000512.27 & TA-54 Area G (by QA) \\
\hline 000512.31 & TA-3 \\
\hline 000512.35 & TA-54 Area G-2 (back fence) \\
\hline 000512.36 & TA-54 Area G-3 (by office) \\
\hline 000512.38 & TA-54 Area G-QA (next to \# 27) \\
\hline 000512.39 & TA-49-QA (adjacent to \# 26) \\
\hline 000512.50 & TA-54 - Area G - expansion \\
\hline 000512.51 & TA-54 - Area G - expansion pit \\
\hline 000512.60 & LA Canyon \\
\hline 000512.76 & TA-15-41 (formerly -61) \\
\hline 000512.77 & TA-36 IJ site \\
\hline 000512.78 & TA-15-N \\
\hline 000513.04 & Barranca School \\
\hline 000513.06 & 48th Street (Twin Tanks Complex) \\
\hline 000513.07 & Gulf/Exxon/Shell Station \\
\hline 000513.08 & McDonalds \\
\hline 000513.09 & Los Alamos Airport \\
\hline 000513.10 & Eastgate \\
\hline 000513.11 & Well PM-1 (E. Jemez Road) \\
\hline 000513.13 & Rocket Park (formerly Piñon School) \\
\hline 000513.14 & Pajarito Acres \\
\hline 000513.15 & White Rock Fire Station \\
\hline 000513.16 & White Rock Nazarene Church \\
\hline 000513.20 & TA-21 Area B \\
\hline 000513.23 & TA-5 (formerly TA-52, Beta Site) \\
\hline 000513.49 & Pajarito Road (TA-36) \\
\hline 000513.61 & LA Hospital \\
\hline 000513.62 & Crossroads Bible Church (formerly Trinity Bible Church) \\
\hline 000513.63 & Monte Rey South \\
\hline 000513.66 & Los Alamos Inn - South \\
\hline 000513.71 & TA-21.01 (NW Bldg 344) \\
\hline 000514.12 & Royal Crest Trailer Court \\
\hline 000514.17 & Bandelier Fire Lookout (near park entrance) \\
\hline 000514.25 & TA- $16-450$ \\
\hline 000514.26 & TA-49 \\
\hline 000514.27 & TA-54 Area G (by QA) \\
\hline 000514.30 & Pajarito Booster $2(\mathrm{P}-2)$ \\
\hline 000514.31 & TA-3 \\
\hline 000514.32 & Los Alamos County Landfill \\
\hline 000514.34 & TA-54 Area G-1 (behind trailer) \\
\hline 000514.35 & TA-54 Area G-2 (back fence) \\
\hline 000514.36 & TA-54 Area G-3 (by office) \\
\hline 000514.38 & TA-54 Area G-QA (next to \# 27) \\
\hline 000514.39 & TA-49-QA (adjacent to \# 26) \\
\hline 000514.45 & TA-54 - Area G/ Southeast Perimeter \\
\hline 000514.47 & TA-54 - Area G/ North Perimeter \\
\hline 000514.51 & TA-54 - Area G - expansion pit \\
\hline 000514.60 & LA Canyon \\
\hline 000514.77 & TA-36 IJ site \\
\hline
\end{tabular}

$\underset{\left(\mathrm{aCi} / \mathrm{m}^{3}\right)}{\operatorname{Air} \text { Concentration }} \quad \begin{gathered}\text { 2s Uncertainty } \\ \left(\mathrm{aCi} / \mathrm{m}^{3}\right)\end{gathered}$

$-48 \quad 118$

$-61 \quad 113$

$7-91$

1161

$12 \quad 95$

$12 \quad 77$

$-11$

$14-109$

75

$-19-85$

$-45 \quad 73$

$-28 \quad 100$

$-7-91$

$125 \quad 109$

$-21 \quad 92$

$\begin{array}{ll}-21 & 88\end{array}$

$\begin{array}{lc}-20 & 90\end{array}$

$-73 \quad 114$

$1-135$

$42-139$

$-63 \quad 132$

111

1

$-73 \quad 184$

$-9 \quad 128$

$-63 \quad 108$

$\begin{array}{ll}-8 & 55\end{array}$

$-3-34$

$-23-33$

$-35-60$

$-18-83$

$51-137$

146

$\begin{array}{ll}8 & 68\end{array}$

$36-149$

$-63 \quad 102$

6

$42-93$

$78-197$

0

$-59-89$

$35-92$

$27-110$

$-74-91$

$27-75$

$-25-80$

32

$19-83$

-7
-7

$-7 \quad 101$

$48-108$

$-57-86$

$30-83$

$-54-69$

$-27 \quad 82$

$-72 \quad 88$

$25-104$ 


\section{Table A-21. Biweekly and Short-term Uranium-238 Concentrations for May 2000 Samples}

\author{
Air Concentration \\ $\left(\mathbf{a C i} / \mathbf{m}^{3}\right)$
}

${ }^{238} \mathbf{U}$

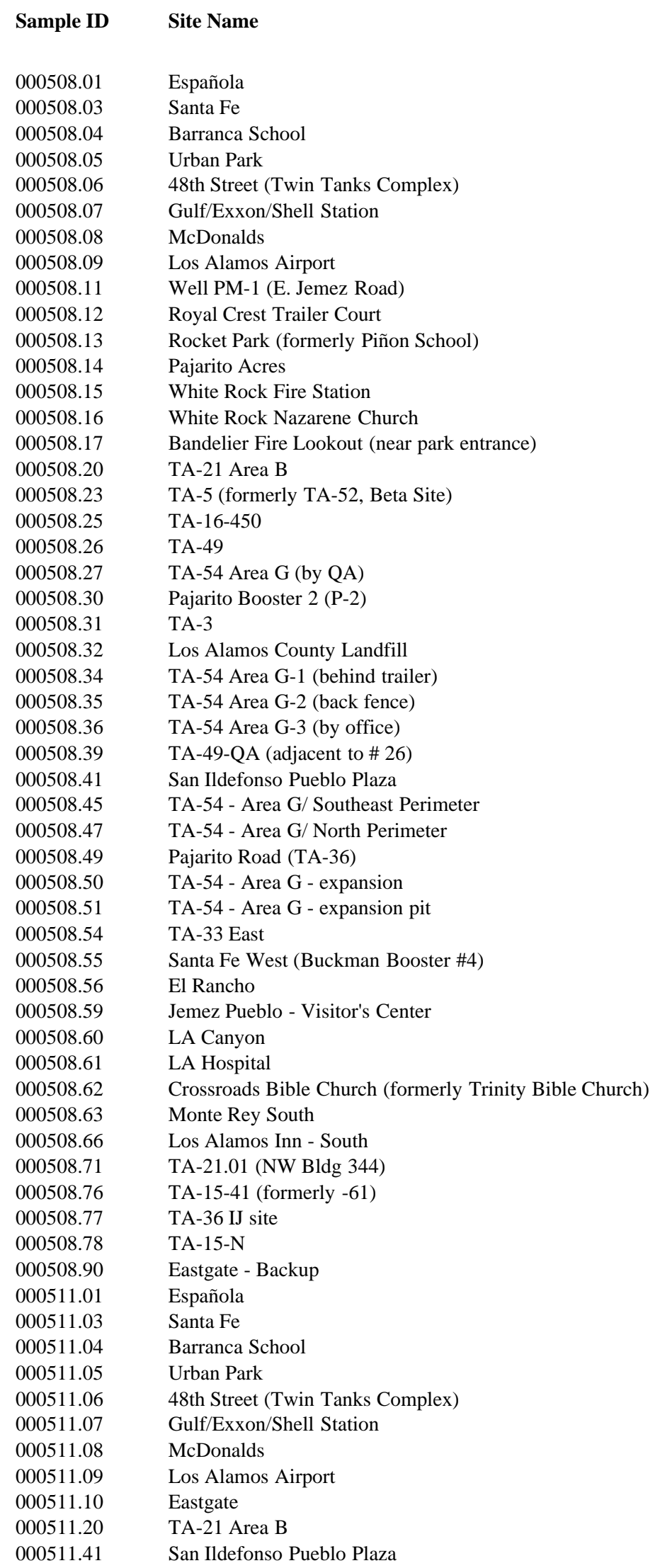

\begin{tabular}{|c|c|}
\hline Sample ID & Site Name \\
\hline 000508.01 & Española \\
\hline 000508.03 & Santa Fe \\
\hline 000508.04 & Barranca School \\
\hline 000508.05 & Urban Park \\
\hline 000508.06 & 48th Street (Twin Tanks Complex) \\
\hline 000508.07 & Gulf/Exxon/Shell Station \\
\hline 000508.08 & McDonalds \\
\hline 000508.09 & Los Alamos Airport \\
\hline 000508.11 & Well PM-1 (E. Jemez Road) \\
\hline 000508.12 & Royal Crest Trailer Court \\
\hline 000508.13 & Rocket Park (formerly Piñon School) \\
\hline 000508.14 & Pajarito Acres \\
\hline 000508.15 & White Rock Fire Station \\
\hline 000508.16 & White Rock Nazarene Church \\
\hline 000508.17 & Bandelier Fire Lookout (near park entrance) \\
\hline 000508.20 & TA-21 Area B \\
\hline 000508.23 & TA-5 (formerly TA-52, Beta Site) \\
\hline 000508.25 & TA-16-450 \\
\hline 000508.26 & TA-49 \\
\hline 000508.27 & TA-54 Area G (by QA) \\
\hline 000508.30 & Pajarito Booster 2 (P-2) \\
\hline 000508.31 & TA-3 \\
\hline 000508.32 & Los Alamos County Landfill \\
\hline 000508.34 & TA-54 Area G-1 (behind trailer) \\
\hline 000508.35 & TA-54 Area G-2 (back fence) \\
\hline 000508.36 & TA-54 Area G-3 (by office) \\
\hline 000508.39 & TA-49-QA (adjacent to \# 26) \\
\hline 000508.41 & San Ildefonso Pueblo Plaza \\
\hline 000508.45 & TA-54 - Area G/ Southeast Perimeter \\
\hline 000508.47 & TA-54 - Area G/ North Perimeter \\
\hline 000508.49 & Pajarito Road (TA-36) \\
\hline 000508.50 & TA-54 - Area G - expansion \\
\hline 000508.51 & TA-54 - Area G - expansion pit \\
\hline 000508.54 & TA-33 East \\
\hline 000508.55 & Santa Fe West (Buckman Booster \#4) \\
\hline 000508.56 & El Rancho \\
\hline 000508.59 & Jemez Pueblo - Visitor's Center \\
\hline 000508.60 & LA Canyon \\
\hline 000508.61 & LA Hospital \\
\hline 000508.62 & Crossroads Bible Church (formerly Trinity Bible Church) \\
\hline 000508.63 & Monte Rey South \\
\hline 000508.66 & Los Alamos Inn - South \\
\hline 000508.71 & TA-21.01 (NW Bldg 344) \\
\hline 000508.76 & TA-15-41 (formerly -61) \\
\hline 000508.77 & TA-36 IJ site \\
\hline 000508.78 & TA-15-N \\
\hline 000508.90 & Eastgate - Backup \\
\hline 000511.01 & Española \\
\hline 000511.03 & Santa Fe \\
\hline 000511.04 & Barranca School \\
\hline 000511.05 & Urban Park \\
\hline 000511.06 & 48th Street (Twin Tanks Complex) \\
\hline 000511.07 & Gulf/Exxon/Shell Station \\
\hline 000511.08 & McDonalds \\
\hline 000511.09 & Los Alamos Airport \\
\hline 000511.10 & Eastgate \\
\hline 000511.20 & TA-21 Area B \\
\hline 000511.41 & San Ildefonso Pueblo Plaza \\
\hline
\end{tabular}
2s Uncertainty $\left(\mathrm{aCi} / \mathrm{m}^{3}\right)$

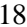


Table A-21 (cont.)

\begin{tabular}{|c|c|}
\hline Sample ID & Site Name \\
\hline 000511.55 & Santa Fe West (Buckman Booster \#4) \\
\hline 000511.56 & El Rancho \\
\hline 000511.61 & LA Hospital \\
\hline 000511.62 & Crossroads Bible Church (formerly Trinity Bible Church) \\
\hline 000511.71 & TA-21.01 (NW Bldg 344) \\
\hline 000512.17 & Bandelier Fire Lookout (near park entrance) \\
\hline 000512.25 & TA- $16-450$ \\
\hline 000512.26 & TA-49 \\
\hline 000512.27 & TA-54 Area G (by QA) \\
\hline 000512.31 & TA-3 \\
\hline 000512.35 & TA-54 Area G-2 (back fence) \\
\hline 000512.36 & TA-54 Area G-3 (by office) \\
\hline 000512.38 & TA-54 Area G-QA (next to \# 27) \\
\hline 000512.39 & TA-49-QA (adjacent to \# 26) \\
\hline 000512.50 & TA-54 - Area G - expansion \\
\hline 000512.51 & TA-54 - Area G - expansion pit \\
\hline 000512.60 & LA Canyon \\
\hline 000512.76 & TA-15-41 (formerly -61) \\
\hline 000512.77 & TA-36 IJ site \\
\hline 000512.78 & TA-15-N \\
\hline 000513.04 & Barranca School \\
\hline 000513.06 & 48th Street (Twin Tanks Complex) \\
\hline 000513.07 & Gulf/Exxon/Shell Station \\
\hline 000513.08 & McDonalds \\
\hline 000513.09 & Los Alamos Airport \\
\hline 000513.10 & Eastgate \\
\hline 000513.11 & Well PM-1 (E. Jemez Road) \\
\hline 000513.13 & Rocket Park (formerly Piñon School) \\
\hline 000513.14 & Pajarito Acres \\
\hline 000513.15 & White Rock Fire Station \\
\hline 000513.16 & White Rock Nazarene Church \\
\hline 000513.20 & TA-21 Area B \\
\hline 000513.23 & TA-5 (formerly TA-52, Beta Site) \\
\hline 000513.49 & Pajarito Road (TA-36) \\
\hline 000513.61 & LA Hospital \\
\hline 000513.62 & Crossroads Bible Church (formerly Trinity Bible Church) \\
\hline 000513.63 & Monte Rey South \\
\hline 000513.66 & Los Alamos Inn - South \\
\hline 000513.71 & TA-21.01 (NW Bldg 344) \\
\hline 000514.12 & Royal Crest Trailer Court \\
\hline 000514.17 & Bandelier Fire Lookout (near park entrance) \\
\hline 000514.25 & TA- $16-450$ \\
\hline 000514.26 & TA-49 \\
\hline 000514.27 & TA-54 Area G (by QA) \\
\hline 000514.30 & Pajarito Booster 2 (P-2) \\
\hline 000514.31 & TA-3 \\
\hline 000514.32 & Los Alamos County Landfill \\
\hline 000514.34 & TA-54 Area G-1 (behind trailer) \\
\hline 000514.35 & TA-54 Area G-2 (back fence) \\
\hline 000514.36 & TA-54 Area G-3 (by office) \\
\hline 000514.38 & TA-54 Area G-QA (next to \# 27) \\
\hline 000514.39 & TA-49-QA (adjacent to \# 26) \\
\hline 000514.45 & TA-54 - Area G/ Southeast Perimeter \\
\hline 000514.47 & TA-54 - Area G/ North Perimeter \\
\hline 000514.51 & TA-54 - Area G - expansion pit \\
\hline 000514.60 & LA Canyon \\
\hline 000514.77 & TA-36 IJ site \\
\hline
\end{tabular}

$\underset{\left(\mathrm{aCi} / \mathrm{m}^{3}\right)}{\operatorname{Air} \text { Concentration }} \quad \begin{gathered}\text { 2s Uncertainty } \\ \left(\mathrm{aCi} / \mathrm{m}^{3}\right)\end{gathered}$

$39 \quad 114$

$72 \quad 136$

252

145

$108+87$

$127 \quad 93$

186

$92 \quad 106$

$416 \quad 144$

234

$52 \quad 89$

$\begin{array}{ll}-7 & 87\end{array}$

$700 \quad 162$

$177 \quad 106$

$700 \quad 166$

275

$122 \quad 109$

$-11$

243

$-10 \quad 131$

$163 \quad 134$

342223

541

$294 \quad 201$

284

$381-153$

$91 \quad 64$

$22 \quad 37$

$9-34$

$\begin{array}{ll}78 & 67\end{array}$

$49-84$

$290-155$

$4188 \quad 618$

$89 \quad 81$

$276-215$

$217 \quad 144$

$28 \quad 39$

$307 \quad 169$

279233

119

$93-107$

$62-92$

$164 \quad 132$

$68-2-2=0$

$696-185$

0

$549-190$

112

$28-114$

$-30-96$

$20-92$

$83-128$

$42 \quad 83$

$54-80$

$35 \quad 92$

$52-132$

$193-151$ 


\section{Table A-22. Biweekly and Short-term Uranium, Plutonium, and Americium Concentrations above their 3s Uncertainties}

\begin{tabular}{|c|c|c|c|c|c|c|}
\hline \multirow[t]{2}{*}{ Sample ID } & \multirow[t]{2}{*}{ Site Name } & \multicolumn{5}{|c|}{ Air Concentration $\left(\mathrm{aCi} / \mathrm{m}^{3}\right)$} \\
\hline & & ${ }^{241} \mathrm{Am}$ & ${ }^{239} \mathbf{P u}$ & ${ }^{234} \mathbf{U}$ & ${ }^{238} \mathbf{U}$ & $\begin{array}{c}\text { Excess } \\
{ }^{234} \mathbf{U}^{\text {or } 238} \mathbf{U}\end{array}$ \\
\hline 000508.01 & Española & & & 39 & 31 & \\
\hline 000508.03 & Santa Fe & & & 73 & 68 & \\
\hline 000508.04 & Barranca School & & & 44 & 47 & \\
\hline 000508.07 & Gulf/Exxon/Shell Station & & & 68 & 62 & \\
\hline 000508.08 & McDonalds & & & 36 & & \\
\hline 000508.11 & Well PM-1 (E. Jemez Road) & & & & 27 & \\
\hline 000508.14 & Pajarito Acres & & & 28 & 28 & \\
\hline 000508.16 & White Rock Nazarene Church & & & 43 & & \\
\hline 000508.17 & Bandelier Fire Lookout & & & & 21 & \\
\hline 000508.20 & TA-21 Area B & & & 71 & 76 & \\
\hline 000508.27 & TA-54 Area G (by QA) & & & 77 & 64 & \\
\hline 000508.31 & TA-3 & & & & 24 & \\
\hline 000508.32 & Los Alamos County Landfill & & & 81 & 71 & \\
\hline 000508.34 & TA-54 Area G-1 (behind trailer) & 92 & & 175 & 169 & \\
\hline 000508.36 & TA-54 Area G-3 (by office) & & & 30 & 21 & \\
\hline 000508.39 & TA-49-QA (adjacent to \# 26) & & & & 21 & \\
\hline 000508.41 & San Ildefonso Pueblo Plaza & & & 30 & 37 & \\
\hline 000508.45 & TA-54 - Area G/ Southeast Perimeter & & & 38 & 45 & \\
\hline 000508.47 & TA-54 - Area G/ North Perimeter & & & 158 & 122 & \\
\hline 000508.49 & Pajarito Road (TA-36) & & & & 21 & \\
\hline 000508.50 & TA-54 - Area G - expansion & & & 84 & 87 & \\
\hline 000508.51 & TA-54 - Area G - expansion pit & & & 39 & 39 & \\
\hline 000508.56 & El Rancho & & & 40 & 25 & \\
\hline 000508.59 & Jemez Pueblo - Visitor's Center & & & 37 & 37 & \\
\hline 000508.60 & LA Canyon & & & & 21 & \\
\hline 000508.63 & Monte Rey South & & & & 22 & \\
\hline 000508.66 & Los Alamos Inn - South & & 30 & & & \\
\hline 000508.71 & TA-21.01 (NW Bldg 344) & & & 33 & & \\
\hline 000508.77 & TA-36 IJ site & & & & 29 & \\
\hline 000511.03 & Santa Fe & & & & 280 & \\
\hline 000511.04 & Barranca School & & & 174 & 203 & \\
\hline 000511.07 & Gulf/Exxon/Shell Station & & & 675 & 729 & \\
\hline 000511.08 & McDonalds & & & 468 & 438 & \\
\hline 000511.10 & Eastgate & & & 182 & & \\
\hline 000511.61 & LA Hospital & & & & 252 & \\
\hline 000512.27 & TA-54 Area G (by QA) & & & 420 & 416 & \\
\hline 000512.31 & TA-3 & & & 351 & 234 & \\
\hline 000512.38 & TA-54 Area G-QA (next to \# 27) & & & 675 & 700 & \\
\hline 000512.39 & TA-49-QA (adjacent to \# 26) & & & & 177 & \\
\hline 000512.50 & TA-54 - Area G - expansion & & & 689 & 700 & \\
\hline 000512.51 & TA-54 - Area G - expansion pit & & & 311 & 275 & \\
\hline 000513.06 & 48th Street (Twin Tanks Complex) & & & & 342 & \\
\hline 000513.07 & Gulf/Exxon/Shell Station & & & 556 & 541 & \\
\hline 000513.09 & Los Alamos Airport & & & & 284 & \\
\hline 000513.10 & Eastgate & & & 250 & 381 & \\
\hline 000513.20 & TA-21 Area B & & & & 290 & \\
\hline 000513.23 & TA-5 (formerly TA-52, Beta Site) & & & 1709 & 4188 & ${ }^{238} \mathrm{U}$ \\
\hline
\end{tabular}


Table A-22 (cont.)

Sample ID Site Name

$\begin{array}{ll}000513.62 & \text { Crossroads Bible Church } \\ 000513.66 & \text { Los Alamos Inn - South } \\ 000514.12 & \text { Royal Crest Trailer Court } \\ 000514.30 & \text { Pajarito Booster 2 (P-2) } \\ 000514.32 & \text { Los Alamos County Landfill }\end{array}$

Air Concentration $\left(\mathrm{aCi} / \mathrm{m}^{3}\right)$

$\begin{array}{lllc}{ }^{241} \mathbf{A m} & { }^{239} \mathbf{P u} & { }^{238} \mathbf{U} & { }^{234} \mathbf{U}{ }^{\text {or }}{ }^{238} \mathbf{U} \\ & & 217 & \\ & & 307 & \\ & & 119 & \\ & & 696 & \\ & 337 & 549 & \\ & 455 & \end{array}$


Table A-23. Polonium-210 and Lead-210 Concentrations Measured in May 2000

\begin{tabular}{|c|c|c|}
\hline Analyte & Sample ID & Site Name \\
\hline $\mathrm{Pb}-210$ & 000508.01 & Española \\
\hline $\mathrm{Pb}-210$ & 000508.04 & Barranca School \\
\hline $\mathrm{Pb}-210$ & 000508.06 & 48th Street (Twin Tanks Complex) \\
\hline $\mathrm{Pb}-210$ & 000508.09 & Los Alamos Airport \\
\hline $\mathrm{Pb}-210$ & 000508.15 & White Rock Fire Station \\
\hline $\mathrm{Pb}-210$ & 000508.23 & TA-5 (formerly TA-52, Beta Site) \\
\hline $\mathrm{Pb}-210$ & 000508.30 & Pajarito Booster 2 (P-2) \\
\hline $\mathrm{Pb}-210$ & 000508.31 & TA-3 \\
\hline $\mathrm{Pb}-210$ & 000508.39 & TA-49-QA (adjacent to \# 26) \\
\hline $\mathrm{Pb}-210$ & 000508.45 & TA-54 - Area G/ Southeast Perimeter \\
\hline $\mathrm{Pb}-210$ & 000508.50 & TA-54 - Area G - expansion \\
\hline $\mathrm{Pb}-210$ & 000508.55 & Santa Fe West (Buckman Booster \#4) \\
\hline $\mathrm{Pb}-210$ & 000508.61 & LA Hospital \\
\hline $\mathrm{Pb}-210$ & 000508.90 & Eastgate - Backup \\
\hline $\mathrm{Pb}-210$ & 000511.01 & Española \\
\hline $\mathrm{Pb}-210$ & 000511.04 & Barranca School \\
\hline $\mathrm{Pb}-210$ & 000511.06 & 48th Street (Twin Tanks Complex) \\
\hline $\mathrm{Pb}-210$ & 000511.09 & Los Alamos Airport \\
\hline $\mathrm{Pb}-210$ & 000511.10 & Eastgate \\
\hline $\mathrm{Pb}-210$ & 000511.61 & LA Hospital \\
\hline $\mathrm{Pb}-210$ & 000512.31 & TA-3 \\
\hline $\mathrm{Pb}-210$ & 000512.38 & TA-54 Area G-QA (next to \# 27) \\
\hline $\mathrm{Pb}-210$ & 000512.39 & TA-49-QA (adjacent to \# 26) \\
\hline $\mathrm{Pb}-210$ & 000512.50 & TA-54 - Area G - expansion \\
\hline Po-210 & 000508.01 & Española \\
\hline Po-210 & 000508.04 & Barranca School \\
\hline Po-210 & 000508.06 & 48th Street (Twin Tanks Complex) \\
\hline Po-210 & 000508.09 & Los Alamos Airport \\
\hline Po-210 & 000508.15 & White Rock Fire Station \\
\hline Po-210 & 000508.23 & TA-5 (formerly TA-52, Beta Site) \\
\hline Po-210 & 000508.30 & Pajarito Booster 2 (P-2) \\
\hline Po-210 & 000508.31 & TA-3 \\
\hline Po-210 & 000508.39 & TA-49-QA (adjacent to \# 26) \\
\hline Po-210 & 000508.45 & TA-54 - Area G/ Southeast Perimeter \\
\hline Po-210 & 000508.50 & TA-54 - Area G - expansion \\
\hline Po- 210 & 000508.55 & Santa Fe West (Buckman Booster \#4) \\
\hline Po-210 & 000508.61 & LA Hospital \\
\hline Po-210 & 000508.90 & Eastgate - Backup \\
\hline Po-210 & 000511.01 & Española \\
\hline Po-210 & 000511.04 & Barranca School \\
\hline Po-210 & 000511.06 & 48th Street (Twin Tanks Complex) \\
\hline Po-210 & 000511.09 & Los Alamos Airport \\
\hline Po-210 & 000511.10 & Eastgate \\
\hline Po-210 & 000511.61 & LA Hospital \\
\hline Po-210 & 000512.31 & TA-3 \\
\hline Po-210 & 000512.38 & TA-54 Area G-QA (next to \# 27) \\
\hline Po-210 & 000512.39 & TA-49-QA (adjacent to \# 26) \\
\hline Po-210 & 000512.50 & TA-54 - Area G - expansion \\
\hline
\end{tabular}
Air Concentration
$\left(\mathbf{f C i} / \mathbf{m}^{3}\right)$
2s Uncertainty $\left(\mathrm{fCi} / \mathrm{m}^{3}\right.$ )

$11.9-0.9$

$12.7-0.9$

$11.7 \quad 0.9$

$12.7-0.9$

$11.0 \quad 0.9$

$13.9-0.9$

$11.9-0.9$

$11.7-1.0$

$12.2 \quad 0.9$

$\begin{array}{ll}12.7 & 0.8\end{array}$

$11.0-0.9$

$12.3 \quad 1.0$

$12.3-0.9$

$12.8-0.9$

$13.5-9.1$

$10.5 \quad 5.8$

$\begin{array}{ll}28.6 & 10.7\end{array}$

$23.2 \quad 10.8$

$\begin{array}{ll}7.0 & 5.0\end{array}$

$\begin{array}{ll}16.8 & 6.1\end{array}$

$\begin{array}{ll}18.8 & 5.7\end{array}$

$10.5 \quad 6.4$

$\begin{array}{ll}8.8 & 5.8\end{array}$

$\begin{array}{ll}8.1 & 6.3 \\ 1.7 & 0.2\end{array}$

$\begin{array}{ll}1.7 & 0.2\end{array}$

$\begin{array}{ll}1.9 & 0.2\end{array}$

$2.8 \quad 0.2$

$\begin{array}{ll}2.5 & 0.2\end{array}$

$1.6-0.2$

$\begin{array}{ll}1.1 & 0.2\end{array}$

$1.9 \quad 0.2$

$2.4-0.2$

$2.6-0.2$

$\begin{array}{ll}2.1 & 0.2\end{array}$

$\begin{array}{ll}1.6 & 0.2\end{array}$

$1.8-0.2$

$2.4 \quad 0.2$

$\begin{array}{ll}2.4 & 0.2\end{array}$

$14.8-1.7$

$12.3 \quad 1.4$

$113.7-8.1$

$30.3-2.9$

$16.0-1.6$

$19.6 \quad 2.1$

$15.7-1.6$

$\begin{array}{ll}4.5 & 0.6\end{array}$

$\begin{array}{ll}6.7 & 1.0\end{array}$

$\begin{array}{ll}5.0 & 0.8\end{array}$ 


\section{Table A-24. Polonium-210 and Lead-210 above their 3s Uncertainties}

$\begin{array}{ll}\text { Sample ID } & \text { Site Name } \\ 000508.01 & \text { Española } \\ 000508.04 & \text { Barranca School } \\ 000508.06 & \text { 48th Street (Twin Tanks Complex) } \\ 000508.09 & \text { Los Alamos Airport } \\ 000508.15 & \text { White Rock Fire Station } \\ 000508.23 & \text { TA-5 (formerly TA-52, Beta Site) } \\ 000508.30 & \text { Pajarito Booster 2 (P-2) } \\ 000508.31 & \text { TA-3 } \\ 000508.39 & \text { TA-49-QA (adjacent to \# 26) } \\ 000508.45 & \text { TA-54 - Area G/ Southeast Perimeter } \\ 000508.50 & \text { TA-54-Area G - expansion } \\ 000508.55 & \text { Santa Fe West (Buckman Booster \#4) } \\ 000508.61 & \text { LA Hospital } \\ 000508.90 & \text { Eastgate - Backup } \\ 000511.01 & \text { Española } \\ 000511.04 & \text { Barranca School } \\ 000511.06 & \text { 48th Street (Twin Tanks Complex) } \\ 000511.09 & \text { Los Alamos Airport } \\ 000511.10 & \text { Eastgate } \\ 000511.61 & \text { LA Hospital } \\ 000512.31 & \text { TA-3 } \\ 000512.38 & \text { TA-54 Area G-QA (next to \# 27) } \\ 000512.39 & \text { TA-49-QA (adjacent to \# 26) } \\ 000512.50 & \text { TA-54 - Area G - expansion } \\ 0 & \end{array}$

$\begin{array}{cc}\begin{array}{c}\text { Air Concentration } \\ \left.{ }^{\mathbf{2 1}} \mathbf{P b} \mathbf{f} \mathbf{C} / \mathbf{m}^{\mathbf{3}}\right)\end{array} \\ { }^{\mathbf{2 1 0}} \mathbf{P o} \\ 11.9 & 1.7 \\ 12.7 & 1.9 \\ 11.7 & 2.8 \\ 12.7 & 2.5 \\ 11.0 & 1.6 \\ 13.9 & 2.1 \\ 11.9 & 1.9 \\ 11.7 & 2.4 \\ 12.2 & 2.6 \\ 12.7 & 2.1 \\ 11.0 & 1.6 \\ 12.3 & 1.8 \\ 12.3 & 2.4 \\ 12.8 & 2.4 \\ & 14.8 \\ 10.5 & 12.3 \\ 28.6 & 113.7 \\ 23.2 & 30.3 \\ & 16.0 \\ 16.8 & 19.6 \\ 18.8 & 15.7 \\ 10.5 & 4.5 \\ 8.8 & 6.7 \\ 11.1 & 5.0 \\ & \end{array}$


Table A-25. Americium-241 Concentrations for 2000 Quarter 2

\begin{tabular}{|c|c|}
\hline Sample ID & Site Name \\
\hline 00Q2.01 & Española \\
\hline $00 \mathrm{Q} 2.03$ & Santa $\mathrm{Fe}$ \\
\hline 00Q2.04 & Barranca School \\
\hline 00Q2.05 & Urban Park \\
\hline 00Q2.06 & 48th Street (Twin Tanks Complex) \\
\hline 00Q2.07 & Gulf/Exxon/Shell Station \\
\hline 00Q2.08 & McDonalds \\
\hline 00Q2.09 & Los Alamos Airport \\
\hline 00Q2.10 & Eastgate \\
\hline 00Q2.11 & Well PM-1 (E. Jemez Road) \\
\hline 00Q2.12 & Royal Crest Trailer Court \\
\hline $00 \mathrm{Q} 2.13$ & Rocket Park (formerly Piñon School) \\
\hline $00 \mathrm{Q} 2.14$ & Pajarito Acres \\
\hline $00 \mathrm{Q} 2.15$ & White Rock Fire Station \\
\hline 00Q2.16 & White Rock Nazarene Church \\
\hline 00Q2.17 & Bandelier Fire Lookout \\
\hline 00Q2.20 & TA-21 Area B \\
\hline 00Q2.23 & TA-5 (formerly TA-52, Beta Site) \\
\hline 00Q2.25 & TA-16-450 \\
\hline $00 \mathrm{Q} 2.26$ & TA-49 \\
\hline 00Q2.27 & TA-54 Area G (by QA) \\
\hline $00 \mathrm{Q} 2.30$ & Pajarito Booster $2(\mathrm{P}-2)$ \\
\hline $00 \mathrm{Q} 2.31$ & TA-3 \\
\hline $00 \mathrm{Q} 2.32$ & Los Alamos County Landfill \\
\hline 00Q2.34 & TA-54 Area G-1 (behind trailer) \\
\hline $00 \mathrm{Q} 2.35$ & TA-54 Area G-2 (back fence) \\
\hline $00 \mathrm{Q} 2.36$ & TA-54 Area G-3 (by office) \\
\hline 00Q2.38 & TA-54 Area G-QA (next to \# 27) \\
\hline 00Q2.39 & TA-49-QA (adjacent to \# 26) \\
\hline $00 \mathrm{Q} 2.41$ & San Ildefonso Pueblo Plaza \\
\hline 00Q2.45 & TA-54 - Area G/ Southeast Perimeter \\
\hline 00Q2.47 & TA-54 - Area G/ North Perimeter \\
\hline 00Q2.49 & Pajarito Road (TA-36) \\
\hline $00 \mathrm{Q} 2.50$ & TA-54 - Area G - expansion \\
\hline 00Q2.51 & TA-54 - Area G - expansion pit \\
\hline 00Q2.54 & TA-33 East \\
\hline 00Q2.55 & Santa Fe West (Buckman Booster \#4) \\
\hline 00Q2.56 & El Rancho \\
\hline 00Q2.59 & Jemez Pueblo - Visitor's Center \\
\hline 00Q2.60 & LA Canyon \\
\hline 00Q2.61 & LA Hospital \\
\hline 00Q2.62 & Crossroads Bible Church \\
\hline 00Q2.63 & Monte Rey South \\
\hline 00Q2.66 & Los Alamos Inn - South \\
\hline 00Q2.71 & TA-21.01 (NW Bldg 344) \\
\hline 00Q2.76 & TA-15-41 (formerly -61) \\
\hline 00Q2.77 & TA-36 IJ site \\
\hline 00Q2.78 & TA-15-N \\
\hline
\end{tabular}

${ }^{241} \mathrm{Am}$

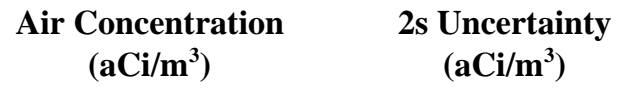

$-0.1 \quad 4.9$

$-0.4 \quad 4.0$

$0.3 \quad 4.6$

$\begin{array}{rl}0.3 & 4.5\end{array}$

$-1.6 \quad 5.5$

$2.2 \quad 5.0$

$1.6 \quad 4.0$

$2.1 \quad 6.3$

$1.0 \quad 5.1$

$0.4 \quad 3.8$

$2.0 \quad 4.2$

$-0.1 \quad 3.5$

$0.2 \quad 3.4$

$0.2 \quad 3.9$

$0.4 \quad 3.6$

$\begin{array}{ll}0.3 & 3.9\end{array}$

$\begin{array}{ll}1.3 & 3.7\end{array}$

$\begin{array}{ll}1.1 & 4.2\end{array}$

$\begin{array}{ll}0.0 & 3.9\end{array}$

$\begin{array}{ll}-0.1 & 3.7\end{array}$

$12.3 \quad 5.8$

$\begin{array}{ll}2.0 & 4.4\end{array}$

$-0.2 \quad 4.4$

$1.1 \quad 4.6$

$64.9 \quad 10.4$

$\begin{array}{ll}-0.4 & 3.5\end{array}$

$\begin{array}{ll}-2.3 & 3.3\end{array}$

$\begin{array}{ll}11.6 & 7.9\end{array}$

$\begin{array}{ll}-1.0 & 4.6\end{array}$

$\begin{array}{ll}-1.6 & 3.2\end{array}$

$\begin{array}{ll}3.0 & 4.1\end{array}$

$1.5 \quad 4.0$

$\begin{array}{ll}0.1 & 3.9\end{array}$

$2.4 \quad 5.8$

$2.5 \quad 4.4$

$\begin{array}{ll}-0.9 & 3.3\end{array}$

$3.2 \quad 4.7$

$1.8 \quad 4.0$

$0.5 \quad 4.5$

$1.2 \quad 4.0$

$\begin{array}{ll}1.1 & 4.7\end{array}$

$\begin{array}{ll}0.6 & 3.8\end{array}$

$\begin{array}{ll}-0.1 & 3.4\end{array}$

$\begin{array}{ll}0.4 & 5.7\end{array}$

$0.4 \quad 3.6$

$0.3 \quad 4.0$

$0.3 \quad 4.0$

$\begin{array}{ll}-0.9 & 3.6\end{array}$ 


\section{Table A-26. Plutonium-238 Concentrations for 2000 Quarter 2}

${ }^{238} \mathrm{Pu}$

\begin{tabular}{|c|c|}
\hline Sample ID & Site Name \\
\hline 00Q2.01 & Española \\
\hline 00Q2.03 & Santa Fe \\
\hline 00Q2.04 & Barranca School \\
\hline $00 \mathrm{Q} 2.05$ & Urban Park \\
\hline $00 Q 2.06$ & 48th Street (Twin Tanks Complex) \\
\hline 00Q2.07 & Gulf/Exxon/Shell Station \\
\hline 00Q2.08 & McDonalds \\
\hline 00Q2.09 & Los Alamos Airport \\
\hline 00Q2.10 & Eastgate \\
\hline 00Q2.11 & Well PM-1 (E. Jemez Road) \\
\hline 00Q2.12 & Royal Crest Trailer Court \\
\hline 00Q2.13 & Rocket Park (formerly Piñon School) \\
\hline 00Q2.14 & Pajarito Acres \\
\hline $00 \mathrm{Q} 2.15$ & White Rock Fire Station \\
\hline 00Q2.16 & White Rock Nazarene Church \\
\hline 00Q2.17 & Bandelier Fire Lookout \\
\hline 00Q2.20 & TA-21 Area B \\
\hline 00Q2.23 & TA-5 (formerly TA-52, Beta Site) \\
\hline 00Q2.25 & TA-16-450 \\
\hline $00 \mathrm{Q} 2.26$ & TA-49 \\
\hline 00Q2.27 & TA-54 Area G (by QA) \\
\hline 00Q2.30 & Pajarito Booster 2 (P-2) \\
\hline 00Q2.31 & TA-3 \\
\hline 00Q2.32 & Los Alamos County Landfill \\
\hline 00Q2.34 & TA-54 Area G-1 (behind trailer) \\
\hline 00Q2.35 & TA-54 Area G-2 (back fence) \\
\hline 00Q2.36 & TA-54 Area G-3 (by office) \\
\hline 00Q2.38 & TA-54 Area G-QA (next to \# 27) \\
\hline 00Q2.39 & TA-49-QA (adjacent to \# 26) \\
\hline 00Q2.41 & San Ildefonso Pueblo Plaza \\
\hline $00 \mathrm{Q} 2.45$ & TA-54 - Area G/ Southeast Perimeter \\
\hline $00 \mathrm{Q} 2.47$ & TA-54 - Area G/ North Perimeter \\
\hline 00Q2.49 & Pajarito Road (TA-36) \\
\hline 00Q2.50 & TA-54 - Area G - expansion \\
\hline 00Q2.51 & TA-54 - Area G - expansion pit \\
\hline 00Q2.54 & TA-33 East \\
\hline 00Q2.55 & Santa Fe West (Buckman Booster \#4) \\
\hline 00Q2.56 & El Rancho \\
\hline 00Q2.59 & Jemez Pueblo - Visitor's Center \\
\hline 00Q2.60 & LA Canyon \\
\hline 00Q2.61 & LA Hospital \\
\hline 00Q2.62 & Crossroads Bible Church \\
\hline 00Q2.63 & Monte Rey South \\
\hline 00Q2.66 & Los Alamos Inn - South \\
\hline 00Q2.71 & TA-21.01 (NW Bldg 344) \\
\hline 00Q2.76 & TA-15-41 (formerly -61) \\
\hline 00Q2.77 & TA-36 IJ site \\
\hline 00Q2.78 & TA-15-N \\
\hline
\end{tabular}

\author{
Air Concentration \\ $\left(\mathrm{aCi} / \mathrm{m}^{3}\right)$ \\ 2s Uncertainty
}

$-1.1$

1.6

$-0.3 \quad 1.2$

$0.6 \quad 2.0$

$-0.4 \quad 1.3$

$0.4 \quad 1.9$

$-0.7-1.5$

$-0.5 \quad 1.0$

$0.9-2.8$

$1.1 \quad 2.4$

$-1.2 \quad 1.2$

$0.4 \quad 1.7$

$0.7 \quad 1.6$

$-0.2-1.1$

$-0.6-1.1$

$0.1 \quad 1.7$

$-0.7 \quad 1.2$

$\begin{array}{ll}0.1 & 1.7\end{array}$

$\begin{array}{ll}-0.8 & 1.7\end{array}$

$-0.6 \quad 1.4$

$0.4 \quad 1.6$

$0.1 \quad 1.7$

$\begin{array}{ll}-0.2 & 1.4\end{array}$

$0.1 \quad 2.1$

$\begin{array}{ll}0.3 & 2.2 \\ 7.5 & 3.7\end{array}$

$\begin{array}{ll}7.5 & 3.7\end{array}$

$\begin{array}{ll}-0.4 & 1.1\end{array}$

$0.6 \quad 1.4$

$1.1 \quad 2.7$

$\begin{array}{ll}-0.4 & 2.2 \\ -0.2\end{array}$

$-0.2 \quad 1.2$

$\begin{array}{ll}-0.7 & 2.0 \\ 3.6 & \end{array}$

$3.6 \quad 2.6$

$-0.3 \quad 1.3$

$-0.5 \quad 1.6$

$-0.2 \quad 1.3$

$\begin{array}{ll}-0.9 & 1.2\end{array}$

$-1.0 \quad 1.3$

$\begin{array}{ll}-0.2 & 1.1\end{array}$

$0.1 \quad 2.1$

$0.1 \quad 1.4$

$\begin{array}{ll}-0.1 & 1.8\end{array}$

$0.1 \quad 1.2$

$0.5 \quad 1.6$

$\begin{array}{ll}1.4 & 2.7\end{array}$

$\begin{array}{ll}0.4 & 1.7\end{array}$

$0.3 \quad 1.4$

$-1.3 \quad 1.6$

$\begin{array}{ll}-0.6 & 1.7\end{array}$ 
Table A-27. Plutonium-239 Concentrations for 2000 Quarter 2

\begin{tabular}{|c|c|}
\hline Sample ID & Site Name \\
\hline 00Q2.01 & Española \\
\hline 00Q2.03 & Santa Fe \\
\hline 00Q2.04 & Barranca School \\
\hline $00 \mathrm{Q} 2.05$ & Urban Park \\
\hline $00 \mathrm{Q} 2.06$ & 48th Street (Twin Tanks Complex) \\
\hline 00Q2.07 & Gulf/Exxon/Shell Station \\
\hline 00Q2.08 & McDonalds \\
\hline 00Q2.09 & Los Alamos Airport \\
\hline $00 \mathrm{Q} 2.10$ & Eastgate \\
\hline 00Q2.11 & Well PM-1 (E. Jemez Road) \\
\hline 00Q2.12 & Royal Crest Trailer Court \\
\hline $00 \mathrm{Q} 2.13$ & Rocket Park (formerly Piñon School) \\
\hline 00Q2.14 & Pajarito Acres \\
\hline $00 Q 2.15$ & White Rock Fire Station \\
\hline 00Q2.16 & White Rock Nazarene Church \\
\hline 00Q2.17 & Bandelier Fire Lookout \\
\hline 00Q2.20 & TA-21 Area B \\
\hline 00Q2.23 & TA-5 (formerly TA-52, Beta Site) \\
\hline 00Q2.25 & TA-16-450 \\
\hline 00Q2.26 & TA-49 \\
\hline $00 \mathrm{Q} 2.27$ & TA-54 Area G (by QA) \\
\hline 00Q2.30 & Pajarito Booster 2 (P-2) \\
\hline 00Q2.31 & TA-3 \\
\hline 00Q2.32 & Los Alamos County Landfill \\
\hline 00Q2.34 & TA-54 Area G-1 (behind trailer) \\
\hline 00Q2.35 & TA-54 Area G-2 (back fence) \\
\hline 00Q2.36 & TA-54 Area G-3 (by office) \\
\hline 00Q2.38 & TA-54 Area G-QA (next to \# 27) \\
\hline 00Q2.39 & TA-49-QA (adjacent to \# 26) \\
\hline $00 \mathrm{Q} 2.41$ & San Ildefonso Pueblo Plaza \\
\hline 00Q2.45 & TA-54 - Area G/ Southeast Perimeter \\
\hline 00Q2.47 & TA-54 - Area G/ North Perimeter \\
\hline 00Q2.49 & Pajarito Road (TA-36) \\
\hline $00 Q 2.50$ & TA-54 - Area G - expansion \\
\hline 00Q2.51 & TA-54 - Area G - expansion pit \\
\hline 00Q2.54 & TA-33 East \\
\hline 00Q2.55 & Santa Fe West (Buckman Booster \#4) \\
\hline 00Q2.56 & El Rancho \\
\hline $00 \mathrm{Q} 2.59$ & Jemez Pueblo - Visitor's Center \\
\hline $00 \mathrm{Q} 2.60$ & LA Canyon \\
\hline 00Q2.61 & LA Hospital \\
\hline $00 \mathrm{Q} 2.62$ & Crossroads Bible Church \\
\hline $00 \mathrm{Q} 2.63$ & Monte Rey South \\
\hline $00 \mathrm{Q} 2.66$ & Los Alamos Inn - South \\
\hline 00Q2.71 & TA-21.01 (NW Bldg 344) \\
\hline 00Q2.76 & TA-15-41 (formerly -61) \\
\hline 00Q2.77 & TA-36 IJ site \\
\hline 00Q2.78 & TA-15-N \\
\hline
\end{tabular}

\begin{tabular}{|c|c|}
\hline $\begin{array}{l}\text { Air Concentration } \\
\qquad\left(\mathrm{aCi} / \mathbf{m}^{3}\right)\end{array}$ & $\begin{array}{l}\text { 2s Uncertainty } \\
\quad\left(\mathbf{a C i} / \mathbf{m}^{3}\right)\end{array}$ \\
\hline-0.6 & 3.2 \\
\hline-1.2 & 2.7 \\
\hline 2.3 & 3.5 \\
\hline 1.0 & 2.8 \\
\hline 0.0 & 4.3 \\
\hline 11.3 & 5.5 \\
\hline 4.8 & 3.1 \\
\hline 2.4 & 4.9 \\
\hline 3.0 & 4.1 \\
\hline 0.5 & 2.1 \\
\hline 2.3 & 3.2 \\
\hline 0.3 & 2.4 \\
\hline-0.7 & 1.5 \\
\hline 2.4 & 2.8 \\
\hline 0.5 & 2.0 \\
\hline 0.2 & 2.4 \\
\hline 5.5 & 3.2 \\
\hline 7.1 & 3.8 \\
\hline 0.0 & 2.7 \\
\hline-0.4 & 2.4 \\
\hline 16.2 & 5.2 \\
\hline-0.1 & 2.5 \\
\hline 2.7 & 3.7 \\
\hline 7.2 & 4.9 \\
\hline 12.8 & 4.5 \\
\hline 0.6 & 2.5 \\
\hline 1.1 & 2.6 \\
\hline 14.7 & 6.6 \\
\hline-1.2 & 3.4 \\
\hline 0.0 & 2.0 \\
\hline 3.2 & 3.0 \\
\hline 2.2 & 3.1 \\
\hline-0.2 & 2.1 \\
\hline 3.2 & 3.8 \\
\hline 1.7 & 2.6 \\
\hline 0.3 & 2.0 \\
\hline-0.6 & 2.9 \\
\hline 0.0 & 1.9 \\
\hline 1.0 & 3.1 \\
\hline-0.5 & 2.4 \\
\hline 2.2 & 3.4 \\
\hline 2.8 & 3.3 \\
\hline-0.3 & 1.8 \\
\hline 30.7 & 9.1 \\
\hline 3.5 & 3.1 \\
\hline 0.8 & 2.6 \\
\hline-0.1 & 2.3 \\
\hline-1.3 & 2.0 \\
\hline
\end{tabular}




\section{Table A-28. Uranium-234 Concentrations for 2000 Quarter 2}

${ }^{234} \mathbf{U}$

\begin{tabular}{|c|c|}
\hline Sample ID & Site Name \\
\hline 00Q2.01 & Española \\
\hline 00Q2.03 & Santa Fe \\
\hline 00Q2.04 & Barranca School \\
\hline 00Q2.05 & Urban Park \\
\hline 00Q2.06 & 48th Street (Twin Tanks Complex) \\
\hline 00Q2.07 & Gulf/Exxon/Shell Station \\
\hline 00Q2.08 & McDonalds \\
\hline 00Q2.09 & Los Alamos Airport \\
\hline 00Q2.10 & Eastgate \\
\hline 00Q2.11 & Well PM-1 (E. Jemez Road) \\
\hline 00Q2.12 & Royal Crest Trailer Court \\
\hline 00Q2.13 & Rocket Park (formerly Piñon School) \\
\hline 00Q2.14 & Pajarito Acres \\
\hline 00Q2.15 & White Rock Fire Station \\
\hline 00Q2.16 & White Rock Nazarene Church \\
\hline 00Q2.17 & Bandelier Fire Lookout \\
\hline 00Q2.20 & TA-21 Area B \\
\hline 00Q2.23 & TA-5 (formerly TA-52, Beta Site) \\
\hline 00Q2.25 & TA-16-450 \\
\hline 00Q2.26 & TA-49 \\
\hline 00Q2.27 & TA-54 Area G (by QA) \\
\hline 00Q2.30 & Pajarito Booster 2 (P-2) \\
\hline 00Q2.31 & TA-3 \\
\hline 00Q2.32 & Los Alamos County Landfill \\
\hline 00Q2.34 & TA-54 Area G-1 (behind trailer) \\
\hline 00Q2.35 & TA-54 Area G-2 (back fence) \\
\hline 00Q2.36 & TA-54 Area G-3 (by office) \\
\hline 00Q2.38 & TA-54 Area G-QA (next to \# 27) \\
\hline 00Q2.39 & TA-49-QA (adjacent to \# 26) \\
\hline 00Q2.41 & San Ildefonso Pueblo Plaza \\
\hline 00Q2.45 & TA-54 - Area G/ Southeast Perimeter \\
\hline 00Q2.47 & TA-54 - Area G/ North Perimeter \\
\hline 00Q2.49 & Pajarito Road (TA-36) \\
\hline 00Q2.50 & TA-54 - Area G - expansion \\
\hline 00Q2.51 & TA-54 - Area G - expansion pit \\
\hline 00Q2.54 & TA-33 East \\
\hline 00Q2.55 & Santa Fe West (Buckman Booster \#4) \\
\hline 00Q2.56 & El Rancho \\
\hline 00Q2.59 & Jemez Pueblo - Visitor's Center \\
\hline 00Q2.60 & LA Canyon \\
\hline 00Q2.61 & LA Hospital \\
\hline 00Q2.62 & Crossroads Bible Church \\
\hline 00Q2.63 & Monte Rey South \\
\hline 00Q2.66 & Los Alamos Inn - South \\
\hline 00Q2.71 & TA-21.01 (NW Bldg 344) \\
\hline 00Q2.76 & TA-15-41 (formerly -61) \\
\hline 00Q2.77 & TA-36 IJ site \\
\hline 00Q2.78 & TA-15-N \\
\hline
\end{tabular}

\begin{tabular}{|c|c|}
\hline $\begin{array}{l}\text { Air Concentration } \\
\qquad\left(\mathbf{a C i} / \mathbf{m}^{3}\right)\end{array}$ & $\begin{array}{l}\text { 2s Uncertainty } \\
\qquad\left(\mathrm{aCi} / \mathbf{m}^{3}\right)\end{array}$ \\
\hline 25.1 & 6.4 \\
\hline 47.3 & 7.5 \\
\hline 23.8 & 5.1 \\
\hline 15.7 & 5.7 \\
\hline 11.2 & 5.9 \\
\hline 94.5 & 11.9 \\
\hline 25.1 & 5.0 \\
\hline 16.8 & 7.3 \\
\hline 28.7 & 7.1 \\
\hline 16.4 & 5.3 \\
\hline 28.7 & 6.5 \\
\hline 15.9 & 5.5 \\
\hline 9.1 & 3.8 \\
\hline 17.0 & 5.1 \\
\hline 15.4 & 4.5 \\
\hline 13.3 & 4.5 \\
\hline 44.2 & 7.7 \\
\hline 59.2 & 7.9 \\
\hline 14.7 & 5.0 \\
\hline 15.0 & 4.8 \\
\hline 105.7 & 12.5 \\
\hline 32.6 & 6.0 \\
\hline 26.1 & 5.9 \\
\hline 77.8 & 11.5 \\
\hline 114.7 & 11.0 \\
\hline 17.9 & 5.6 \\
\hline 17.0 & 4.8 \\
\hline 92.2 & 10.3 \\
\hline 13.6 & 5.8 \\
\hline 20.7 & 6.3 \\
\hline 38.0 & 5.9 \\
\hline 97.9 & 9.2 \\
\hline 0.0 & 4.9 \\
\hline 74.1 & 9.0 \\
\hline 44.0 & 6.9 \\
\hline 14.3 & 5.1 \\
\hline 14.6 & 5.6 \\
\hline 30.2 & 6.8 \\
\hline 42.2 & 8.6 \\
\hline 16.3 & 4.8 \\
\hline 22.1 & 6.1 \\
\hline 17.7 & 5.3 \\
\hline 15.9 & 5.3 \\
\hline 21.3 & 7.1 \\
\hline 19.3 & 5.0 \\
\hline 12.2 & 4.9 \\
\hline 26.1 & 5.6 \\
\hline 28.6 & 5.8 \\
\hline
\end{tabular}


Table A-29. Uranium-235 Concentrations for 2000 Quarter 2

\begin{tabular}{|c|c|c|c|}
\hline \multirow[b]{2}{*}{ Sample ID } & \multirow[b]{2}{*}{ Site Name } & \multicolumn{2}{|c|}{${ }^{235} \mathbf{U}$} \\
\hline & & $\begin{array}{c}\text { Air Concentration } \\
\left(\mathbf{a C i} / \mathbf{m}^{3}\right)\end{array}$ & $\begin{array}{l}\text { 2s Uncertainty } \\
\left(\mathbf{a C i} / \mathbf{m}^{3}\right)\end{array}$ \\
\hline 00Q2.01 & Española & 0.8 & 3.4 \\
\hline 00Q2.03 & Santa Fe & 3.5 & 3.3 \\
\hline 00Q2.04 & Barranca School & 2.2 & 3.2 \\
\hline $00 Q 2.05$ & Urban Park & 0.9 & 2.4 \\
\hline $00 Q 2.06$ & 48th Street (Twin Tanks Complex) & -0.8 & 4.1 \\
\hline 00Q2.07 & Gulf/Exxon/Shell Station & 4.9 & 4.0 \\
\hline 00Q2.08 & McDonalds & 0.5 & 2.1 \\
\hline 00Q2.09 & Los Alamos Airport & 2.7 & 4.6 \\
\hline 00Q2.10 & Eastgate & -0.1 & 4.0 \\
\hline 00Q2.11 & Well PM-1 (E. Jemez Road) & 0.4 & 2.2 \\
\hline 00Q2.12 & Royal Crest Trailer Court & 2.6 & 2.8 \\
\hline 00Q2.13 & Rocket Park (formerly Piñon School) & 0.2 & 2.1 \\
\hline 00Q2.14 & Pajarito Acres & 0.2 & 2.0 \\
\hline 00Q2.15 & White Rock Fire Station & 0.8 & 2.5 \\
\hline 00Q2.16 & White Rock Nazarene Church & 0.8 & 2.1 \\
\hline 00Q2.17 & Bandelier Fire Lookout & 1.5 & 3.0 \\
\hline 00Q2.20 & TA-21 Area B & 2.3 & 2.7 \\
\hline 00Q2.23 & TA-5 (formerly TA-52, Beta Site) & 1.4 & 3.1 \\
\hline 00Q2.25 & TA-16-450 & 0.3 & 2.7 \\
\hline 00Q2.26 & TA-49 & -0.9 & 2.8 \\
\hline 00Q2.27 & TA-54 Area G (by QA) & 5.0 & 3.3 \\
\hline 00Q2.30 & Pajarito Booster 2 (P-2) & 1.7 & 2.9 \\
\hline 00Q2.31 & TA-3 & 0.4 & 3.2 \\
\hline 00Q2.32 & Los Alamos County Landfill & 3.5 & 4.2 \\
\hline 00Q2.34 & TA-54 Area G-1 (behind trailer) & 3.7 & 2.7 \\
\hline 00Q2.35 & TA-54 Area G-2 (back fence) & 0.4 & 2.1 \\
\hline 00Q2.36 & TA-54 Area G-3 (by office) & 0.8 & 2.5 \\
\hline 00Q2.38 & TA-54 Area G-QA (next to \# 27) & 0.7 & 4.1 \\
\hline 00Q2.39 & TA-49-QA (adjacent to \# 26) & 3.3 & 3.8 \\
\hline $00 \mathrm{Q} 2.41$ & San Ildefonso Pueblo Plaza & 0.5 & 2.1 \\
\hline $00 \mathrm{Q} 2.45$ & TA-54 - Area G/ Southeast Perimeter & 1.1 & 2.7 \\
\hline 00Q2.47 & TA-54 - Area G/ North Perimeter & 6.6 & 3.4 \\
\hline 00Q2.49 & Pajarito Road (TA-36) & 3.5 & 2.9 \\
\hline $00 \mathrm{Q} 2.50$ & TA-54 - Area G - expansion & 1.4 & 3.8 \\
\hline $00 \mathrm{Q} 2.51$ & TA-54 - Area G - expansion pit & 2.5 & 3.1 \\
\hline $00 Q 2.54$ & TA-33 East & 1.0 & 2.7 \\
\hline 00Q2.55 & Santa Fe West (Buckman Booster \#4) & -0.2 & 3.0 \\
\hline $00 \mathrm{Q} 2.56$ & El Rancho & -0.6 & 2.6 \\
\hline 00Q2.59 & Jemez Pueblo - Visitor's Center & 2.4 & 2.7 \\
\hline 00Q2.60 & LA Canyon & 0.4 & 2.5 \\
\hline 00Q2.61 & LA Hospital & 0.1 & 3.2 \\
\hline 00Q2.62 & Crossroads Bible Church & 0.4 & 2.2 \\
\hline 00Q2.63 & Monte Rey South & 0.1 & 2.0 \\
\hline 00Q2.66 & Los Alamos Inn - South & 2.3 & 3.4 \\
\hline 00Q2.71 & TA-21.01 (NW Bldg 344) & 0.1 & 2.1 \\
\hline 00Q2.76 & TA-15-41 (formerly -61) & -1.6 & 2.5 \\
\hline 00Q2.77 & TA-36 IJ site & 0.5 & 2.6 \\
\hline 00Q2.78 & TA-15-N & 2.6 & 2.2 \\
\hline
\end{tabular}


Table A-30. Uranium-238 Concentrations for 2000 Quarter 2

\begin{tabular}{|c|c|c|c|}
\hline \multirow[b]{2}{*}{ Sample ID } & \multirow[b]{2}{*}{ Site Name } & \multicolumn{2}{|c|}{${ }^{238} \mathbf{U}$} \\
\hline & & $\begin{array}{l}\text { Air Concentration } \\
\qquad\left(\mathbf{a C i} / \mathbf{m}^{3}\right)\end{array}$ & $\begin{array}{c}\text { 2s Uncertainty } \\
\qquad\left(\mathrm{aCi} / \mathbf{m}^{3}\right)\end{array}$ \\
\hline 00Q2.01 & Española & 24.8 & 5.8 \\
\hline 00Q2.03 & Santa Fe & 40.3 & 6.5 \\
\hline 00Q2.04 & Barranca School & 29.6 & 4.7 \\
\hline 00Q2.05 & Urban Park & 17.0 & 5.4 \\
\hline 00Q2.06 & 48th Street (Twin Tanks Complex) & 16.1 & 5.8 \\
\hline 00Q2.07 & Gulf/Exxon/Shell Station & 111.0 & 12.6 \\
\hline 00Q2.08 & McDonalds & 27.6 & 4.8 \\
\hline 00Q2.09 & Los Alamos Airport & 23.3 & 6.7 \\
\hline 00Q2.10 & Eastgate & 35.8 & 7.2 \\
\hline 00Q2.11 & Well PM-1 (E. Jemez Road) & 21.2 & 5.0 \\
\hline 00Q2.12 & Royal Crest Trailer Court & 25.1 & 5.6 \\
\hline 00Q2.13 & Rocket Park (formerly Piñon School) & -0.5 & 4.6 \\
\hline 00Q2.14 & Pajarito Acres & 8.8 & 3.5 \\
\hline 00Q2.15 & White Rock Fire Station & 20.5 & 5.1 \\
\hline 00Q2.16 & White Rock Nazarene Church & 13.6 & 4.2 \\
\hline 00Q2.17 & Bandelier Fire Lookout & 12.5 & 4.0 \\
\hline 00Q2.20 & TA-21 Area B & 45.4 & 7.5 \\
\hline 00Q2.23 & TA-5 (formerly TA-52, Beta Site) & 85.1 & 8.9 \\
\hline 00Q2.25 & TA-16-450 & 13.4 & 4.1 \\
\hline 00Q2.26 & TA-49 & 15.6 & 4.5 \\
\hline 00Q2.27 & TA-54 Area G (by QA) & 104.2 & 12.4 \\
\hline 00Q2.30 & Pajarito Booster 2 (P-2) & 56.0 & 7.5 \\
\hline 00Q2.31 & TA-3 & 23.5 & 5.3 \\
\hline 00Q2.32 & Los Alamos County Landfill & 84.5 & 11.3 \\
\hline 00Q2.34 & TA-54 Area G-1 (behind trailer) & 104.6 & 10.9 \\
\hline 00Q2.35 & TA-54 Area G-2 (back fence) & 17.4 & 4.7 \\
\hline 00Q2.36 & TA-54 Area G-3 (by office) & 17.9 & 4.9 \\
\hline 00Q2.38 & TA-54 Area G-QA (next to \# 27) & 86.9 & 9.2 \\
\hline 00Q2.39 & TA-49-QA (adjacent to \# 26) & 17.9 & 5.3 \\
\hline 00Q2.41 & San Ildefonso Pueblo Plaza & 17.6 & 5.4 \\
\hline 00Q2.45 & TA-54 - Area G/ Southeast Perimeter & 42.2 & 5.7 \\
\hline 00Q2.47 & TA-54 - Area G/ North Perimeter & 92.0 & 8.8 \\
\hline 00Q2.49 & Pajarito Road (TA-36) & 17.8 & 5.2 \\
\hline $00 \mathrm{Q} 2.50$ & TA-54 - Area G - expansion & 77.8 & 9.2 \\
\hline 00Q2.51 & TA-54 - Area G - expansion pit & 45.6 & 6.7 \\
\hline 00Q2.54 & TA-33 East & 9.9 & 4.2 \\
\hline 00Q2.55 & Santa Fe West (Buckman Booster \#4) & 8.9 & 4.6 \\
\hline 00Q2.56 & El Rancho & 27.4 & 6.0 \\
\hline 00Q2.59 & Jemez Pueblo - Visitor's Center & 46.6 & 8.4 \\
\hline $00 \mathrm{Q} 2.60$ & LA Canyon & 20.8 & 4.5 \\
\hline 00Q2.61 & LA Hospital & 27.1 & 6.1 \\
\hline 00Q2.62 & Crossroads Bible Church & 17.7 & 4.4 \\
\hline 00Q2.63 & Monte Rey South & 12.3 & 4.5 \\
\hline 00Q2.66 & Los Alamos Inn - South & 28.8 & 7.6 \\
\hline 00Q2.71 & TA-21.01 (NW Bldg 344) & 15.9 & 4.7 \\
\hline 00Q2.76 & TA-15-41 (formerly -61) & 23.7 & 5.1 \\
\hline 00Q2.77 & TA-36 IJ site & 44.5 & 6.4 \\
\hline 00Q2.78 & TA-15-N & 53.1 & 7.5 \\
\hline
\end{tabular}


Table A-31. Quarterly Uranium, Plutonium, and Americium Concentrations above their 3s Uncertainties

\begin{tabular}{|c|c|}
\hline Sample ID & Site Name \\
\hline 00Q2.01 & Española \\
\hline 00Q2.03 & Santa Fe \\
\hline 00Q2.04 & Barranca School \\
\hline 00Q2.05 & Urban Park \\
\hline 00Q2.06 & 48th Street (Twin Tanks Complex) \\
\hline 00Q2.07 & Gulf/Exxon/Shell Station \\
\hline 00Q2.08 & McDonalds \\
\hline 00Q2.09 & Los Alamos Airport \\
\hline 00Q2.10 & Eastgate \\
\hline 00Q2.11 & Well PM-1 (E. Jemez Road) \\
\hline 00Q2.12 & Royal Crest Trailer Court \\
\hline 00Q2.13 & Rocket Park (formerly Piñon School) \\
\hline 00Q2.14 & Pajarito Acres \\
\hline 00Q2.15 & White Rock Fire Station \\
\hline 00Q2.16 & White Rock Nazarene Church \\
\hline 00Q2.17 & Bandelier Fire Lookout \\
\hline 00Q2.20 & TA-21 Area B \\
\hline $00 Q 2.23$ & TA-5 (formerly TA-52, Beta Site) \\
\hline $00 Q 2.25$ & TA-16-450 \\
\hline 00Q2.26 & TA-49 \\
\hline 00Q2.27 & TA-54 Area G (by QA) \\
\hline 00Q2.30 & Pajarito Booster $2(\mathrm{P}-2)$ \\
\hline 00Q2.31 & TA-3 \\
\hline 00Q2.32 & Los Alamos County Landfill \\
\hline 00Q2.34 & TA-54 Area G-1 (behind trailer) \\
\hline 00Q2.35 & TA-54 Area G-2 (back fence) \\
\hline 00Q2.36 & TA-54 Area G-3 (by office) \\
\hline 00Q2.38 & TA-54 Area G-QA (next to \# 27) \\
\hline 00Q2.39 & TA-49-QA (adjacent to \# 26) \\
\hline 00Q2.41 & San Ildefonso Pueblo Plaza \\
\hline 00Q2.45 & TA-54 - Area G/ Southeast Perimeter \\
\hline 00Q2.47 & TA-54 - Area G/ North Perimeter \\
\hline 00Q2.49 & Pajarito Road (TA-36) \\
\hline 00Q2.50 & TA-54 - Area G - expansion \\
\hline 00Q2.51 & TA-54 - Area G - expansion pit \\
\hline 00Q2.54 & TA-33 East \\
\hline 00Q2.55 & Santa Fe West (Buckman Booster \#4) \\
\hline 00Q2.56 & El Rancho \\
\hline 00Q2.59 & Jemez Pueblo - Visitor's Center \\
\hline 00Q2.60 & LA Canyon \\
\hline 00Q2.61 & LA Hospital \\
\hline 00Q2.62 & Crossroads Bible Church \\
\hline 00Q2.63 & Monte Rey South \\
\hline 00Q2.66 & Los Alamos Inn - South \\
\hline 00Q2.71 & TA-21.01 (NW Bldg 344) \\
\hline 00Q2.76 & TA-15-41 (formerly -61) \\
\hline
\end{tabular}

\begin{tabular}{|c|c|c|c|c|c|c|}
\hline & & Air & entrati & $\mathrm{Ci} / \mathbf{m}^{3}$ & & \\
\hline${ }^{241} \mathrm{Am}$ & ${ }^{238} \mathbf{P u}$ & ${ }^{239} \mathbf{P u}$ & ${ }^{234} \mathbf{U}$ & ${ }^{235} \mathbf{U}$ & ${ }^{238} \mathbf{U}$ & Excess U \\
\hline & & & 25.1 & & 24.8 & \\
\hline & & & 47.3 & & 40.3 & \\
\hline & & & 23.8 & & 29.6 & \\
\hline & & & 15.7 & & 17.0 & \\
\hline & & & 11.2 & & 16.1 & \\
\hline & & 11.3 & 94.5 & & 111.0 & \\
\hline & & 4.8 & 25.1 & & 27.6 & \\
\hline & & & 16.8 & & 23.3 & \\
\hline & & & 28.7 & & 35.8 & \\
\hline & & & 16.4 & & 21.2 & \\
\hline & & & 28.7 & & 25.1 & \\
\hline & & & 15.9 & & & ${ }^{234} \mathrm{U}$ \\
\hline & & & 9.1 & & 8.8 & \\
\hline & & & 17.0 & & 20.5 & \\
\hline & & & 15.4 & & 13.6 & \\
\hline & & & 13.3 & & 12.5 & \\
\hline & & 5.5 & 44.2 & & 45.4 & \\
\hline & & 7.1 & 59.2 & & 85.1 & ${ }^{238} \mathrm{U}$ \\
\hline & & & 14.7 & & 13.4 & \\
\hline & & & 15.0 & & 15.6 & \\
\hline 12.3 & & 16.2 & 105.7 & 5.0 & 104.2 & \\
\hline & & & 32.6 & & 56.0 & ${ }^{238} \mathrm{U}$ \\
\hline & & & 26.1 & & 23.5 & \\
\hline & & & 77.8 & & 84.5 & \\
\hline 64.9 & 7.5 & 12.8 & 114.7 & & 104.6 & \\
\hline & & & 17.9 & & 17.4 & \\
\hline & & & 17.0 & & 17.9 & \\
\hline & & 14.7 & 92.2 & & 86.9 & \\
\hline & & & 13.6 & & 17.9 & \\
\hline & & & 20.7 & & 17.6 & \\
\hline & & & 38.0 & & 42.2 & \\
\hline & & & 97.9 & 6.6 & 92.0 & \\
\hline & & & & & 17.8 & ${ }^{238} \mathrm{U}$ \\
\hline & & & 74.1 & & 77.8 & \\
\hline & & & 44.0 & & 45.6 & \\
\hline & & & 14.3 & & 9.9 & \\
\hline & & & 14.6 & & 8.9 & \\
\hline & & & 30.2 & & 27.4 & \\
\hline & & & 42.2 & & 46.6 & \\
\hline & & & 16.3 & & 20.9 & \\
\hline & & & 22.1 & & 27.1 & \\
\hline & & & 17.7 & & 17.7 & \\
\hline & & & 15.9 & & 12.3 & \\
\hline & & 30.7 & 21.3 & & 28.8 & \\
\hline & & & 19.7 & & 15.9 & \\
\hline & & & 12.2 & & 23.7 & ${ }^{238} \mathrm{U}$ \\
\hline
\end{tabular}


Table A-31 (cont.)

Sample ID Site Name

${ }^{241} \mathrm{Am} \quad{ }^{238} \mathbf{P u}$

Air Concentration $\left(\mathrm{aCi} / \mathrm{m}^{3}\right)$

00Q2.77 TA-36 IJ site

00Q2.78 TA-15-N

\begin{tabular}{|c|c|c|c|}
\hline${ }^{239} \mathrm{Pu}$ & ${ }^{234} \mathbf{U}$ & ${ }^{238} \mathbf{U}$ & Excess U \\
\hline & 26.1 & 44.5 & ${ }^{238} \mathrm{U}$ \\
\hline & 28.6 & 53.1 & ${ }^{238} \mathrm{U}$ \\
\hline
\end{tabular}


This report has been reproduced directly from the best available copy. It is available electronically on the Web (http://www.doe.gov/bridge).

Copies are available for sale to U.S. Department of Energy employees and contractors from:

Office of Scientific and Technical Information

P.O. Box 62

Oak Ridge, TN 37831

(865) 576-8401

Copies are available for sale to the public from: National Technical Information Service

U.S. Department of Commerce

5285 Port Royal Road

Springfield, VA 22161

(800) 553-6847 
- Los Alamos NATIONAL LABORATORY 